Lucia Helena Borges Meneghetti

\title{
Dados digitais no espaço público: visibilidade e vigilância distribuída na cidade contemporânea
}


LUCIA HELENA BORGES MENEGHETTI

Dados digitais no espaço público: visibilidade e vigilância distribuída na cidade contemporânea

\section{Versão Original}

Dissertação apresentada à Faculdade de Arquitetura e Urbanismo da Universidade de São Paulo para obtenção do título de Mestre em Arquitetura e Urbanismo.

Área de Concentração: Projeto, espaço e cultura.

Orientadora: Profa. Dra. Giselle Beiguelman. 
Autorizo a reprodução e divulgação total ou parcial deste trabalho, por qualquer meio convencional ou eletrônico, para fins de estudo e pesquisa, desde que citada a fonte.

E-mails: luciameneghetti@usp.br

luciameneghetti@yahoo.com.br

Catalogação na Publicação

Serviço Técnico de Biblioteca

Faculdade de Arquitetura e Urbanismo da Universidade de São Paulo

Meneghetti, Lucia

Dados digitais no espaço público: visibilidade e

vigilância distribuída na cidade contemporânea / Lucia

Meneghetti; orientador Giselle Beiguelman. - São Paulo, 2020 .

$95 \mathrm{f}$.

Dissertação (Mestrado) - Faculdade de Arquitetura e Urbanismo da Universidade de São Paulo. Área de concentração: Projeto, Espaço e Cultura.

1. Espaço Ampliado. 2. Visibilidade. 3. Vigilância. 4. Tecnologias de Informação e Comunicação. I. Beiguelman, Giselle, orient. II. Título. 
Nome: MENEGHETTI, Lucia Helena Borges.

Título: Dados digitais no espaço público: visibilidade e vigilância distribuída na cidade contemporânea

Dissertação apresentada à Faculdade de Arquitetura e Urbanismo da Universidade de São Paulo para obtenção do título de Mestre em Arquitetura e Urbanismo.

Aprovado em:

Banca examinadora:

Prof(a). Dr(a).

Instituição

Julgamento

$\operatorname{Prof}(a) . \operatorname{Dr}(\mathrm{a})$.

Instituição

Julgamento

Prof(a). Dr(a).

Instituição

Julgamento 
Para Guilherme, Cacá e para meus pais. 


\section{AGRADECIMENTOS}

O presente trabalho não teria sido possível sem a generosidade, apoio e colaboração de meus professores, amigos, familiares e diversas outras pessoas e instituições. Agradeço a todos que colaboraram e apoiaram esta jornada, em especial:

À Professora Giselle Beiguelman, pelo acolhimento, por sua orientação preciosa, carregada de confiança e generosidade, e pelo referencial de excelência artística, acadêmica e docência.

Aos professores Dennys Antonialli e Luís Antonio Jorge pelos fundamentais comentários na qualificação.

Ao professor Jorge Bassani pelo diálogo franco e generoso, e por me receber em sua disciplina de graduação como monitora pelo Programa de Aperfeiçoamento em Ensino.

Aos professores Artur Simões Rozestraten, Daniela Kutschat Hanns, Guilherme Teixeira Wisnik, Karina Oliveira Leitão, Leandro Silva Medrano e Maria Cristina da Silva Leme, pela interlocução e colaborações à pesquisa durante os seminários e disciplinas cursadas.

À Biblioteca da FAUUSP e sua equipe pelo acesso ao acervo diverso e qualificado, e pelas inestimáveis orientações durante as oficinas técnicas voltadas para pesquisa acadêmica.

Aos amigos pesquisadores e aos integrantes dos grupos de estudos Estéticas da Memória no Século 21 (EMS21), Devaneios Experimentais e Poéticas Imaginativas (DEPi) e Cenários Urbanos Futuros (CUF), pela interlocução de altíssimo nível.

Às amigas Camila, Mariana, Maristela, Méia e Kati pela amizade inestimável e por compartilharem comigo seus saberes docentes.

À Lícia, Marilú e Nanda pelas atenciosas revisões, carinho e apoio incondicional.

Aos meus lastros nesta travessia, por me proverem o apoio necessário que viabilizou minha dedicação ao presente trabalho: Guigo, Marilú, Luiz e Cacá. 


\section{RESUMO}

MENEGHETTI, Lucia Helena Borges. Dados digitais no espaço público: visibilidade e vigilância distribuída na cidade contemporânea. 2020. 95f. Dissertação (Mestrado em Arquitetura e Urbanismo) - Faculdade de Arquitetura e Urbanismo da Universidade de São Paulo, São Paulo, 2020.

Apoiada no conceito teórico de vigilância de Foucault (1983), atualizado principalmente por Bruno (2013), a pesquisa enfoca o tema das relações entre as práticas de visibilidade e vigilância de indivíduos, potencializadas pelas Tecnologias de Informação e Comunicação (TICs), em espaços híbridos e ampliados da cidade contemporânea. A partir do entendimento das TICs como catalizadoras das interações humanas no espaço urbano, identifica-se e investiga-se situações de captura de dados digitais de cidadãos, com ênfase em espaços públicos e iniciativas de governos brasileiros, com objetivo de compreender como as práticas de visibilidade alimentam sistemas vigilantes em territórios urbanos, e como podem interferir nas noções de espaço e de esfera pública.

Palavras-chave: Cidade Contemporânea; Espaço Ampliado; Visibilidade; Vigilância; Tecnologias de Informação e Comunicação. 


\begin{abstract}
MENEGHETTI, Lucia Helena Borges. Digital data in the public space: visibility and distributed surveillance in the contemporary city. 2020. 95f. Dissertação (Mestrado em Arquitetura e Urbanismo) - Faculdade de Arquitetura e Urbanismo da Universidade de São Paulo, São Paulo, 2020.
\end{abstract}

Supported by the theoretical concept of surveillance by Foucault (1983), updated mainly by Bruno (2013), the research focuses on the theme of the relationships between the practices of visibility and surveillance of individuals, enhanced by Information and Communication Technologies (ICTs), in hybrid and expanded spaces of the contemporary city. Based on the understanding of ICTs as a catalyst for human interactions in the urban space, situations of capturing citizens' digital data are identified and investigated, with an emphasis on public spaces and government initiatives in Brazil, in order to understand how the practices of visibility feed surveillance systems in urban territories, and how they can interfere with the notions of space and the public sphere.

Palavras-chave: Contemporary City; Expanded Space; Visibility; Surveillance; Information and Communication Technologies. 


\section{SUMÁRIO}

INTRODUÇÃO.

1. CAPÍTULO I - TECNOLOGIA, ESPAÇO E VISIBILIDADE

1.1. TICs e os espaços híbridos e ampliados da cidade contemporânea.....

1.2. As assimetrias da visibilidade e as novas margens do visível.

2. CAPÍTULO II - VIGILÂNCIA, OLHAR E INFORMAÇÃO

2.1. A relação entre visibilidade, compartilhamento de dados e vigilância. 26

2.2. Vigilância e reconhecimento facial em espaços públicos urbanos. 31

2.3. Outras situações de captura de dados por parte do poder público brasileiro 42

3. CAPÍTULO III - CULTURA, TERRITORIALIZAÇÃO E CONTROLE

3.1. Cultura e estéticas da vigilância... 56

3.2. Cidades inteligentes, exclusão e novas geografias. 62

4. CONCLUSÕES E CONSIDERAÇÕES FINAIS. 71 REFERÊNCIAS 


\section{INTRODUÇÃO}

Apoiada no conceito teórico de vigilância de Foucault (1983), atualizado principalmente por Bruno (2013), a presente pesquisa possui como tema as relações entre as práticas de visibilidade e vigilância de indivíduos, potencializadas pelas Tecnologias de Informação e Comunicação (TICs), (BRIGHENTI, 2007; BRUNO; FIRMINO; KANASHIRO, 2010; SIBILIA, 2016; HATUKA; TOCH, 2017) em espaços híbridos e ampliados da cidade contemporânea (FERRARA, 2000; SANTOS, 2006; DUARTE; FIRMINO, 2010; LEMOS, 2010; BEIGUELMAN, 2016b). Sua investigação enfoca situações de captura de dados digitais de cidadãos, com ênfase em espaços públicos e iniciativas de governos brasileiros, com objetivo de compreender como as práticas de visibilidade alimentam sistemas vigilantes em territórios urbanos, (VIRILIO, 2012; BRUNO, 2013, 2018; MACHADO; ORTELLADO; RIBEIRO, 2016; SILVEIRA, 2017; AVELINO; SILVEIRA; SOUZA, 2018; LYON, 2018; ZUBOFF, 2018) e como podem interferir na noção de espaço (METAHEAVEN, 2012; BRATTON, 2015; FIRMINO, 2018; BEIGUELMAN, 2016a; BAMBOZZI, 2019) e de esfera pública (KUSTER; PECHMAN, 2014; BIRCHALL, 2017; WISNIK, 2018).

Como metodologia para o desenvolvimento desta pesquisa de caráter predominantemente exploratório, devido à contemporaneidade do tema proposto, se fez necessário o continuo confronto entre: as leituras críticas da bibliografia sobre a temática específica, - que serviu de aporte teórico para o presente trabalho -; e entre o material coletado por meio do acompanhamento de publicações de notícias, relatórios, boletins, (governamentais, jornalísticos e outros), em canais midiáticos, relacionados ao assunto em questão. De uma maneira mais ampla, a busca por aporte teórico se iniciou a partir de inquietações relacionadas às implicações das Tecnologias de Informação e Comunicação na transformação dos espaços em que vivemos. Neste sentido, como fundamentação teórica, a pesquisa considera que os aspectos físicos e sociais do espaço são indissociáveis, pois tem como uma de suas bases as ideias de Santos (2006) - que entende o espaço como um híbrido de materialidades e relações sociais. Neste trabalho, sua visão é retomada por Ferrara (2000), Duarte e Firmino $(2008,2010)$, Lemos (2010) e Beiguelman (2016a), que também abordam a suplementação das Tecnologias de Informação e Comunicação (TICs) em nosso cotidiano físico, que viabiliza por meio da internet, a infiltração entre espacialidades físicas e informacionais diversas. A presente investigação toma seu direcionamento específico 
principalmente a partir das reflexões de Brighenti (2007) e Hatuka e Toch (2017) que ao considerarem a visibilidade como conceito social chave da vida pública, nos permitiram estender a noção de visibilidade para o campo sociológico e compreendê-la não só como algo que pode ser visto com os olhos, mas, como algo desejado por indivíduos que compartilham dados pessoais principalmente em redes sociais digitais com propósito diversos como autopromoção, reconhecimento ou representatividade e acabam por contribuir desta forma para a vigilância distribuída. (BRUNO; FIRMINO; KANASHIRO, 2010; FELDMAN, 2011; RICARDO, 2011; BRUNO, 2013; BEIGUELMAN, 2016a, 2016b; CRARY, 2016; SIBILIA, 2016; BRUNO et al., 2018; LYON, 2018). A partir deste entendimento, os esforços da investigação se debruçam sobre o material teórico sistematizado para assimilar os conceitos, constelação de agentes, interesses, ambiguidades, dispositivos, contextos e consequências em torno da atual relação entre visibilidade, vigilância e captura de dados, principalmente no espaço híbrido e ampliado de cidades brasileiras, para responder às inquietações que moveram essa pesquisa na direção do objetivo explicitado no primeiro parágrafo desta introdução, e por fim apresenta-los neste trabalho.

Desta maneira, a primeira parte do capítulo I - Tecnologia, espaço e visibilidade -, intitulada: TICs e os espaços híbridos e ampliados da cidade contemporânea, conceitua a ideia de infiltração entre diferentes espacialidades (físicas e informacionais), por meio das TICs no cotidiano urbano (DUARTE; FIRMINO, 2008, 2010); conceitua o espaço híbrido e ampliado da cidade contemporânea baseada em autores como: Santos (2006), Bruno, Firmino e Kanashiro (2010), Lemos (2010) e Beiguelman (2016a), entre outros; e demonstra os referidos conceitos usando exemplos que envolvem o espaço público também em cidades brasileiras, relacionando os mesmos à Internet das Coisas em uma escala de proporções urbanas. Já na segunda parte deste mesmo capítulo, chamada: As assimetrias da visibilidade e as novas margens do visível, tendo por base principalmente as pesquisas de Brighenti (2007), Crary (2016), Beiguelman (2016a), Sibilia (2016), Hatuka e Toch (2017), Bruno et al. (2018) e Lyon (2018), discorremos sobre nossa atual condição de produção constante de visibilidades, para abordar a ampliação deste campo para além da visão física, com suas implicações sociais, ambiguidades e assimetrias.

O capítulo II - Vigilância, Olhar e Informação -, foi dividido em três partes. Ao explicitarmos $A$ relação entre visibilidade, compartilhamento de dados e vigilância, - título da primeira parte -, abrimos o referido capítulo do presente trabalho conceituando a vigilância 
distribuída (BRUNO, 2013), e baseados também em Virilio (2012). A segunda parte do capítulo II, chamada: Vigilância e reconhecimento facial em espaços públicos urbanos, aborda situações de captura de dados, também por parte do poder público brasileiro, ligadas principalmente ao primeiro dos elementos-chave dos processos de vigilância: o olhar sobre o que se vigia. A terceira e última parte deste capítulo - Outras situações de captura de dados por parte do poder público brasileiro -, aborda essas outras situações que estão mais ligadas ao segundo dos elementos-chave dos processos de vigilância: as informações sobre o que se vigia (BRUNO, 2013). Estes dois subcapítulos também tratam das possíveis implicações dos casos comentados, como: geração de informações para melhoria da governança pública; ameaças à privacidade, encolhimento da esfera pública, discriminação racial e de gênero, exclusão social, viés tecnológico, e monetização de dados pessoais -; levantadas por autores que pesquisam as referidas situações identificadas, ou que possuem pesquisas sobre temas relacionados a elas, como principalmente: Koskella (2010), Virilio (2012), Machado, Ortellado e Ribeiro (2016), Moll e Parizot (2016), Silveira (2017), Avelino, Silveira e Souza (2018), Bruno, et al (2018), Buolamwini e Gebru (2018), Keyes (2018) e Zuboff (2018).

Por fim, o capítulo III - Cultura, territorialização e controle -, em sua primeira metade, identifica principalmente, de acordo com Lyon (2018), Bruno e Lins (2010), e Beiguelman (2016a, 2016b), características culturais e estéticas comuns da vigilância. Já em sua segunda metade, - Cidades inteligentes, exclusão e novas geografias -, aborda as gerações e conceituações das Smart Cities (GOODSPEED, 2014; RENNÓ, 2016; ROZESTRATEN, 2016; GREENFIELD 2017; FIGUEIREDO, 2018), e suas relações com as parcerias entre governos e empresas privadas para implantação de TICs, que operam geralmente por captura de dados, no espaço híbrido e ampliado da cidade contemporânea, identificando situações de conflito entre os agentes da vigilância que disputam a soberania sobre territórios em uma nova geografia política. (METAHEAVEN, 2012; BRATTON, 2015; BEIGUELMAN 2016a, 2016b, 2019; FIRMINO, 2018). 


\section{CAPÍTULO I - TECNOLOGIA, ESPAÇO E VISIBILIDADE}

\subsection{TICs e os espaços híbridos e ampliados da cidade contemporânea}

Nas últimas décadas, tanto os espaços em que vivemos quanto nossas práticas cotidianas vêm sofrendo profundas transformações, especialmente por conta do desenvolvimento das Tecnologias de Informação e Comunicação - TICs, cuja difusão se deu principalmente a partir dos anos de 1970, (GIRARD, 2017). TICs são constituídas por dispositivos, métodos e mídias cujo objetivo é comunicar, tais como: computadores; internet; telefonia móvel; vídeo, TV, cinema e fotografia digitais entre outros.

À medida que permitem interações entre pessoas que podem estar distantes fisicamente, as TICs potencializam uma das práticas humanas cotidianas e fundamentais para vida em sociedade: as práticas de visibilidade - capacidade do indivíduo ver, se expor e ser visto (HATUKA; TOCH, 2017) - para além dos limites estritamente humanos. $E$, ao potencializar tais práticas, as TICs também acabam por implicar modificações não só em nossa percepção de tempo e espaço, mas também em nossas relações sociais.

Diversos autores apontam maneiras pelas quais a tecnologia tem interferido nas noções de espaço físico. Santos (2006) considera o espaço geográfico do mundo atual como um meio técnico-científico-informacional. O autor, ao tratar de uma cientifização e tecnicização da paisagem, afirma que:

\footnotetext{
A informação não apenas está presente nas coisas, nos objetos técnicos, que formam o espaço, como ela é necessária à ação realizada sobre essas coisas. A informação é o vetor fundamental do processo social e os territórios são, desse modo, equipados para facilitar a sua circulação. (SANTOS, 2006, p.160).
}

O autor considera o espaço um híbrido de materialidades e relações sociais imaterialidades. Ferrara (2000, p.22), também baseada em Santos (2006), diz que "a cidade virtual não substitui a real, mas ambas convivem por meio dos veículos ou canais que reproduzem, nas suas torres, a força da comunicação planetária, ao mesmo tempo, em que é capaz de estimular o imaginário na idealização de outras cidades possíveis". Para esses dois autores os aspectos físicos e sociais do espaço são indissociáveis.

Nesta mesma chave, Duarte e Firmino (2008) empregam termos como "cidade infiltrada" e "cidade ampliada", ao buscarem por "um conceito que considere a adição de 
novos elementos ao espaço, e não a ideia de substituição". Para estes autores, "o espaço, um produto social, deve agora incorporar a complexidade das interações virtuais, remotas e distantes". Este entendimento juntamente com a conceituação de espacialidades "infiltradas" e "ampliadas" são reafirmados e desenvolvidos por estes mesmos autores em outras publicações conjuntas:

Não se trata, portanto, de uma espacialidade que abole o espaço, [...] mas infiltrações entre diferentes espacialidades físicas e informacionais através das redes digitais de comunicação: não se passa "desta" para "outra" espacialidade, mas vivese ambas, que se infiltram e remodelam-se. (DUARTE; FIRMINO, 2010, p. 108).

Mais recentemente, refletindo sobre esta mesma condição não-dicotômica, mas de adição de espacialidades, Beiguelman (2016a) defende que diferentes dispositivos tecnológicos suplementam nosso cotidiano físico com informações, fazendo com que coexistam no mesmo espaço objetos virtuais e reais. Segundo a autora, esta condição de coexistência acaba por borrar a oposição entre espaço real e espaço virtual, proporcionando o entendimento da cidade como conjuntos de territórios híbridos configurados a partir da superposição de fisicalidades e redes informacionais diversas. Lemos (2010) afirma que quando dispositivos eletrônicos criam, a partir de bancos de dados, funções informacionais no espaço físico, configurando o que ele chama de "territórios informacionais", o que entra em disputa é o controle das informações e por consequência uma nova função dos espaços.

Paradoxalmente, as tecnologias que proporcionam e potencializam a exposição do indivíduo e sua visibilidade, passam frequentemente despercebidas devido a sua própria invisibilidade, como também nos mostram os já citados Duarte e Firmino (2010, p. 102) ao abordarem a infiltração entre diferentes espacialidades (físicas e informacionais), por meio das TICs no cotidiano das cidades: “[...] fibras ópticas são subterrâneas, as ondas de rádio são invisíveis e os satélites estão além do alcance de nossa percepção". Ao investigar a histórica, as formas de distribuição espacial e identificar os efeitos das TICs no meio físico urbano, Girard (2017) também aponta para a invisibilidade destas tecnologias ao afirmar que "o impacto das tecnologias de comunicação de massa não é tão perceptível no espaço da cidade quanto no tempo". (GIRARD, 2017, p.35). Ou seja, para o autor, percebemos - ou nos preocupamos mais com a instantaneidade das interações humanas que as TICs propiciam do que com a presença física delas em nosso meio ambiente. Nesta mesma perspectiva, ao analisar as implicações das TICs na percepção dos lugares, Bambozzi (2019, p.13), afirma que "a 
emergência de espaços informacionais nos centros urbanos vem mudando a noção do que é visível e não visível na sociedade e na arte."

Bruno, Firmino e Kanashiro (2010), entendem que os chamados espaços ampliados se formam à medida que sensores tecnológicos que monitoram o espaço físico e informacional, tornam sensíveis processos usualmente despercebidos como maneiras discretas de vigilância de dados. Assim, entendemos que as TICs aumentam as possibilidades de interações humanas - antes limitadas pelo meio físico - principalmente por possibilitarem a adição de camadas informacionais no espaço híbrido de materialidades e relações sociais, e à medida que este processo se torna perceptível, constitui-se o que entendemos como espaços híbridos e ampliados da cidade contemporânea.

Morozov (2018) trata especialmente das implicações políticas do emprego das TICs em nossa sociedade, que de acordo com ele, também pode acentuar a mercantilização das cidades. Uma situação que pode ilustrar as ideias abordadas até agora no presente subcapítulo, exemplificando o conceito de espaço híbrido e ampliado da cidade contemporânea a que este trabalho se refere, é descrita pelo autor em um de seus livros lançados recentemente no Brasil:

\footnotetext{
Uma série de aplicativos, como o Haystack e o MonkeyParking, permitiam que, usando apenas os celulares, motoristas leiloassem vagas públicas de estacionamento para outros motoristas em busca de um lugar para guardar o carro. O Haystack ainda contava com um recurso, Make Me Move, pelo qual os afortunados que encontrassem uma vaga poderiam vendê-la pelo maior lance. Evidentemente, as vagas de estacionamento continuam sendo públicas, o que muda de posse é a informação sobre elas estarem ocupadas ou não. Mas a condição formal, de bem público, significa muito pouco, pois o mercado ilegal da informação o converte em um bem privado dissimuladamente. (MOROZOV, 2018, p. 67).
}

O leilão de vagas públicas para estacionamento de veículos, viabilizado por um dispositivo tecnológico, "amplia" o espaço híbrido de materialidades e relações sociais ao tornar sensível o monitoramento de informações - como a localização georreferenciada dos motoristas -; e evidencia: a) tanto a infiltração entre diferentes espacialidades (físicas e informacionais), por meio das TICs na dinâmica cotidiana das cidades, que é abordada por Duarte e Firmino (2008, 2010); b) quanto o conceito de "territórios informacionais" desenvolvido por Lemos (2010). A camada adicional de informação no espaço físico - no caso, os dados sobre disponibilidade de vagas acessados em tempo real pelos motoristas nas ruas da cidade - coloca em disputa o controle dessas informações e a posse do espaço, embaralha 
os limites entre espaço público e espaço privado, e explicita a mercantilização da cidade, uma vez que quem tem mais poder aquisitivo provavelmente sairia ganhando, pois, em uma situação como esta, ficaria com a vaga. A situação descrita por Morozov (2018), que também foi amplamente noticiada pela imprensa americana, ocorreu em 2014, em importantes cidades dos Estados Unidos, como: Boston, São Francisco e Los Angeles, e outras, onde aplicativos criados para encontrar e vender vagas de estacionamento, como Haystack, MonkeyParking, Sweetch ou ParkModo, haviam sido lançados, gerando polêmicas e rapidamente sofrendo proibições por parte das autoridades públicas municipais locais - que defenderam o direito de acesso ao espaço público para todos, inclusive para quem não poderia pagar por isso -, fazendo com que em meados de 2015 , os aplicativos já não se encontrassem mais em operação da mesma maneira como haviam sido lançados quase um ano antes (BORCHERS, 2014; GOARD, 2014; ORLOV, 2014). Porém, esses aplicativos e outros similares, não deixaram de existir, - pelo contrário, multiplicaram-se, - e passaram a operar em diversos outros países, inclusive no Brasil, agora, com foco na monetização de espaços privados, como por exemplo vagas de estacionamento localizadas em hotéis, condomínios e supermercados (FOLHAPRESS, 2014; CARVALHO, 2016; PEQUENAS EMPRESAS \& GRANDES NEGÓCIOS, 2019). Também no Brasil, não são só os espaços cobertos pelas redes $w i-f i{ }^{1}$ com acesso à internet, que sofrem infiltração entre espacialidades físicas e informacionais diversas. Espaços públicos em cidades brasileiras que não possuem sinal para conexão à internet como, por exemplo, túneis para trânsito de veículos - já estão sofrendo adição de outras camadas informacionais, e também vêm sendo ampliados, por meio de dispositivos tecnológicos de informação e comunicação.

Em 2016 a Companhia de Engenharia de Tráfego do Rio de Janeiro fechou uma parceria com a empresa Waze Mobile ${ }^{2}$ que permitiu a instalação de dispositivos sinalizadores

\footnotetext{
${ }^{1}$ As redes wi-fi, ou redes "sem fio", transmitem informações por meio de ondas de rádio, usando um dispositivo roteador (que recebe e decodifica sinais, e os emite a partir de uma antena). Para que computadores, ou outros dispositivos tecnológicos, tenham acesso a estes sinais, é preciso que permaneçam dentro do alcance destas redes.

2 Pertencente à empresa Google e mundialmente conhecida por seu aplicativo Waze - ferramenta colaborativa para dispositivos móveis baseada em navegação por satélite em tempo real, com foco do trânsito das cidades, que atualmente possui 115 milhões de usuários, sendo 14 milhões deles só no Brasil -, a empresa Waze Mobilie tem cada vez mais se aproximado de governos, por meio de quase 500 parcerias ao longo do globo com instituições como: Depto. de Transporte dos Estados Unidos; Centro de Operações do Rio de Janeiro (Brasil); Centro de Mobilidade de Roma (Itália); entre outros. Mais informações disponíveis em: <https://www.waze.com/pt-BR/ccp>. Acesso em: 03 dez. 2019.
} 
equipados com a tecnologia beacon em túneis da cidade. O chamado Waze Beacon é um dispositivo eletrônico, movido a bateria, que transmite sinais via bluetooth - frequência de rádio de ondas curtas -, para outros dispositivos (como smartphones ou tablets ${ }^{3}$ ), que também possuam o mesmo aplicativo instalado e estejam com seus bluetooth ativados. Os sinais permitem determinar a distância entre os diversos Waze Beacons, que estão instalados nas paredes do túnel, e o aparelho celular do motorista, identificando assim sua localização e transmitindo essa informação ao aplicativo que é visualizado pelo motorista. Ciente da sua posição exata dentro ao túnel, o usuário corre menos risco de perder as saídas e pode evitar acidentes que geralmente ocorrem devido à mudança brusca entre faixas de rolagem na via. Por enquanto ainda são poucas as cidades do mundo que implementaram esses dispositivos tecnológicos em túneis públicos de tráfego de veículos. No Brasil, foi noticiada a instalação de beacons no túnel da Avenida Rebouças e no túnel Zuzu Angel, ambos no Rio de Janeiro (CANALTECH, 2016; O GLOBO, 2016; TAGIAROLI, 2019) ${ }^{4}$. Em 2019, sua instalação também foi divulgada nos túneis que dão acesso à Manhattan, Nova York (BERGER, 2019; PALMER, 2019; PORT AUTHORITY OF NEW YORK \& NEW JERSEY, 2019). Atualmente, empresas anunciam a comercialização de beacons com certificação da Agência Nacional de Telecomunicação (Anatel), e inclusive para produtos fabricados no Brasil, o que na teoria, tornaria a tecnologia financeiramente mais acessível (KNEBEL, 2016; PERIN, 2017) ${ }^{5}$. A implantação destes dispositivos, conectados à internet e também combinados à outras tecnologias, tem sido divulgada, em espaços diversos, como por exemplo: estádios de futebol, (segundo Moraes (2015), o time do Botafogo, no Rio de Janeiro, participou em 2015, de um projeto piloto usando beacons para comunicação com torcedores, visando: o possível direcionamento de campanhas publicitárias; e a melhoria da acessibilidade no Estádio Nilton Santos, mais conhecido como Engenhão. A empresa responsável pela tecnologia também menciona em seu website parcerias em projetos com outros times de futebol como Figueirense e Corinthians ${ }^{6}$ );

\footnotetext{
${ }^{3} \mathrm{O}$ termo Smartphone ou celular inteligente, como tem sido chamado em português, refere-se a um dispositivo de telefonia móvel (celular), equipado com capacidade de acesso à internet, localização georreferenciada por satélite, câmera fotográfica digital, entre outras funcionalidades. O termo de língua inglesa tablet refere-se a um dispositivo eletrônico portátil que agrega algumas funções de processamento de dados de um computador e funções de comunicação via internet e telefonia móvel de um celular (embora geralmente tenha menos capacidade de processamento e seja fisicamente menor que o primeiro e maior que o segundo).

${ }^{4}$ Mais informações disponíveis em: <https://www.waze.com/pt-BR/beacons>. Acesso em: 05 dez. 2019.

5 Mais informações disponíveis em: <http://taggen.com.br/produtos-lot/\#beacon>, e em: $<$ https://useaurea.com/beacons.html>. Acessos em: 06 nov. 2019.

${ }^{6}$ Mais informações disponíveis em: <https://tagpoint.webnode.com/nosso-pessoal/>. Acesso em 06 nov. 2019.
} 
lojas de ruas e de shoppings, (de acordo com Jornal da Globo, (2016), Chiara (2019) e Dias (2019), a partir de 2016, em São Paulo e Vitória, beacons foram instalados em lojas físicas não só para marketing direcionado aos seus compradores, mas também para implantação de estabelecimentos que dispensam a interação dos clientes com outros seres humanos); mobiliário urbano, (encontramos notícias no Jornal Estadão, e no website de um dos fornecedores envolvidos, (GAZZONI, 2016; MURAD, 2016) ${ }^{7}$ sobre a instalação de beacons, na ocasião das Olimpíadas de 2016 no Rio de Janeiro, em relógios digitais, aspersores de água e abrigos de ônibus, localizados em bairros como Copacabana para interação dos transeuntes com peças publicitárias); museu, (segundo G1 (2017), e São Paulo São (2017), a Pinacoteca do Estado de São Paulo, usou beacons no projeto $A$ Voz da Arte realizado em 2017, para interação do público com as obras expostas); e até em praias, (a Prefeitura de Camboriú (2018), cidade que integra a região do litoral catarinense conhecida como Costa Verde \& Mar $^{8}$, divulgou sua participação em um projeto piloto em parceria com empresas privadas ${ }^{9}$, em 2018, que instalou beacons em espaços públicos e privados de atração turística - como praias, praças e edificações históricas - para interagir com seus visitantes).

Não só os beacons, mas também outros dispositivos tecnológicos com diferentes especificidades e aplicações, que possuem papel fundamental na chamada Internet das Coisas ${ }^{10}$, se fazem cada vez mais presentes no trânsito entre cidades, e em objetos e espaços do cotidiano urbano, onde funcionam normalmente conectados à rede mundial de computadores, também adicionando camadas informacionais ao meio físico, e, portanto, contribuindo para a ampliação dos espaços em escala global (BEIGUELMAN, 2016a).

\footnotetext{
${ }_{7}$ Mais informações disponíveis em: <http://ooh.meioemensagem.com.br/clear-channel-uma-midia-infinitaspossibilidades/>. Acesso em 06 nov. 2019.

${ }^{8}$ A região turística brasileira conhecida como Costa Verde \& Mar, localizada no litoral catarinense é constituída atualmente pelos municípios de Camboriú, Balneário Piçarras, Bombinhas, Camboriú, Ilhota, Itajaí, Itapema, Navegantes, Penha e Porto Belo. Mais informações em: <https://costaverdemar.com.br/novo/>. Acesso em 17 dez. 2019.

9 Mais informações disponíveis em: <https://www.sebrae.com.br/sites/PortalSebrae/sebraeaz/destinosturisticos-inteligentes,983d59f53b1bb510VgnVCM1000004c00210aRCRD>. Acesso em 06 nov. 2019.

${ }^{10}$ A expressão em inglês Internet of things (IOT), ou Internet das Coisas, (como foi traduzida em português) foi cunhada pela primeira vez em 1999 por Kevin Ashton (ASHTON, 2009). E como define Beiguelman (2016, p.15), trata-se de um "novo paradigma tecnológico baseado na integração de diversos objetos às redes e interconectados entre si". A expressão é popularmente conhecida por conta das amplas campanhas de vendas das grandes empresas fabricantes de eletrodomésticos, sistemas e objetos "inteligentes" do dia-a-dia, que fazem parte da chamada Internet das Coisas por serem equipados com dispositivos tecnológicos conectados à rede mundial de computadores, permitindo armazenamento, recepção e transmissão de dados e informações entre si e entre a rede, como: geladeiras, torradeiras, assistentes pessoais, autopeças, sistema de climatização e iluminação artificiais em ambientes fechados, entre outros.
} 
Segundo Silveira (2017, p.15), "as tecnologias digitais produzem um conjunto de informações todas as vezes que são utilizadas", o autor ilustra esta ideia ao descrever a diferença entre uma fechadura comum (que não produz registro preciso sobre quantas vezes foi aberta ou fechada, nem informa o horário exato em que uma porta foi trancada), e uma fechadura digital, que: “aberta por um cartão magnético ou por biometria não somente destrava a porta como também registra o horário exato em que isso aconteceu. Também pode registrar qual cartão magnético ou digital abriu a porta, no caso de existir mais que um" (SILVEIRA, 2017, p. 15). É o caso dos dispositivos com tecnologia RFID ${ }^{11}$, e suas tecnologias derivadas, cujas aplicações mais comuns são na indústria e no setor de transporte de produtos e cargas, - onde são usadas etiquetas com RFID principalmente para determinar e transmitir dados, por meio de radiofrequência, a respeito da localização precisa de um objeto monitorado, em tempo real.

Sobre a diversificação dos usos das etiquetas com RFID, Beiguelman (2016a), considera:

\begin{abstract}
Elas podem ser lidas a grandes distâncias e armazenar uma diversidade de informações, sem ser desativadas. São menores que um grão de arroz e cada uma delas é única. Só existe uma para cada produto, mas a sua decodificação remota não é associada a um leitor específico. Permitem, por isso, a otimização de uma série de rotinas do cotidiano e também potencializam o controle e monitoramento da privacidade numa escala sem precedentes. (BEIGUELMAN, 2016a, p. 21).
\end{abstract}

A tecnologia RFID também é comumente usada para troca de informações que viabilizam pagamentos e controle de acessos entre dispositivos eletrônicos por meio de aproximação física sem fio. É o caso, por exemplo, do sistema de bilhetes eletrônicos implantados nos ônibus e metrôs da rede pública para transporte de pessoas ${ }^{12}$, em funcionamento em inúmeras cidades e regiões do território nacional, como por exemplo na cidade de Manaus e nas regiões metropolitanas de Fortaleza, Rio de Janeiro e São Paulo, onde foram instituídos por lei em 2019, 2016, 2009 e 1998 respectivamente (SÃO PAULO, 1998;

\footnotetext{
${ }^{11}$ RFID é a sigla para o termo em inglês: radio frequency identification ou identificação por radiofrequência (tradução nossa). A tecnologia RFID e suas derivadas são amplamente empregadas nos dispositivos tecnológicos presentes nos eletrodomésticos, sistemas e objetos do dia-a-dia "inteligentes", que fazem parte da chamada Internet das Coisas.

${ }^{12}$ Mais informações em: <http://www.prodatamobility.com.br/>, e em: <https://www.teubilhete.com.br/sobreo-teu/>, e em: <http://www.bilheteunicometropolitano.ce.gov.br/rmf.html>, e em: <https://site.riobilheteunico.com.br/>, e em: <http://bilheteunico.sptrans.com.br/>, e em: <http://www.cartaobom.net/index.aspx>. Acessos em: 17 dez. 2019.
} 
RIO DE JANEIRO, 2009; CEARÁ, 2016; DINIZ, 2019).

Portanto, elaborando uma síntese com outras palavras, muitas vezes nos preocupamos tanto com a instantaneidade das interações humanas que as TICs nos propiciam (GIRARD, 2017), que acabamos não nos dando conta de que: implantados desta maneira, conforme mostrado nos parágrafos anteriores - nos mais diversos espaços físicos, meios públicos de transporte e objetos do cotidiano urbano -, os dispositivos tecnológicos, (como os citados neste subcapítulo), tem permitido a interconexão entre os elementos intrínsecos da cidade e entre a rede mundial de computadores, enviando "sem pausa, informações sobre o nosso fazer e o nosso deixar [de fazer]", e participando "ativamente do protocolamento total da nossa vida" (HAN, 2018, p.127), e viabilizando assim, a instauração da Internet das Coisas em uma escala de proporções urbanas (BEIGUELMAN, 2016a, 2018) ${ }^{13}$, e contribuindo também para a ampliação dos espaços em que estão sendo inseridos.

\footnotetext{
${ }^{13} \mathrm{~A}$ instauração da Internet das Coisas em escala urbana também foi um dos principais assuntos apresentados e desenvolvidos pela professora doutora Giselle Beiguelman ao longo das aulas da disciplina "DSG5013 - Arte e Design de Interface em Escala Urbana", ministradas de 13 mar. 2018 a 19 jun. 2018, no programa de pósgraduação Stricto Sensu em Design, na Faculdade de Arquitetura e Urbanismo da Universidade de São Paulo FAUUSP.
} 


\subsection{As assimetrias da visibilidade e as novas margens do visível}

Ao levarem em conta o uso pessoal e a ampla difusão das TICs na atualidade, Hatuka e Toch (2017), baseados em Brighenti (2007), estendem a noção de visibilidade para o campo sociológico, e é deste ponto de vista mais amplo que consideramos esta noção e suas práticas no presente trabalho:

O uso pessoal de dispositivos tecnológicos e, em particular, de tecnologias de localização, também está influenciando os padrões de mobilidade nas cidades, bem como as relações das pessoas com os lugares. Dito de outra forma, a visibilidade deve ser vista como um conceito social chave da vida pública com múltiplos significados que se estendem além da visão física, ou do que pode ser visto com os olhos, para a prática de "ser exposto e conhecido" por meio de várias tecnologias. Esta condição mudou dramaticamente as formas de troca em público. As interações sociais já não se limitam às pessoas em um lugar concreto. Assim, a fisicalidade do espaço não dita as interações sociais, antes, é uma esfera entre muitas. (HATUKA; TOCH, 2017, p.2-3, grifo e tradução nossos) ${ }^{14}$.

Partindo desta mesma perspectiva, ao traçar uma breve trajetória da conversão de dispositivos tecnológicos portáteis (como laptops, tablets e principalmente smartphones), em inesperados meios de comunicação através de sua interconexão com redes digitais de abrangência global, Sibilia (2016, p. 21) afirma que o fenômeno do selfie 15 "dá conta da triunfante junção entre visibilidade e conexão", ajudando o smartphone a "dar vazão às peculiares demandas e ambições que articulam as subjetividades contemporâneas, bem como ao tipo de sociabilidade por elas alicerçada". Deste aspecto, a prática do selfie pode ser entendida como um dos indícios da "reordenação dos regimes de visibilidade que está em curso nas sociedades contemporâneas, o que implica uma reorientação da experiência dos espaços em que vivemos e das tecnologias com as quais lidamos cotidianamente". (BRUNO;

\footnotetext{
14 "The personal use of technological devices and, in particular, of location-aware technologies, is also influencing patterns of mobility throughout cities as well as people's relationships with places. Stated differently, visibility should be seen as a key social concept of public life with multiple meanings that extend beyond physical seeing or what can be seen with the eyes to the practice of 'being exposed and known' through various technologies. This condition has dramatically changed the forms of exchange in public. Social interactions are no longer limited to people in a concrete place. Thus, the physicality of space does not dictate social interactions; rather, it is one sphere among many."

${ }^{15} \mathrm{O}$ termo selfie é um neologismo que se originou da locução de língua inglesa self-portrait, autorretrato. Sua prática tornou-se tão popular que em 2013, foi eleita a palavra do ano pelo Dicionário Oxford, que também popularizou sua definição: um autorretrato tirado com objetivo de ser compartilhado na internet, geralmente em redes sociais online. Mais informações disponíveis em: <http://g1.globo.com/mundo/noticia/2013/11/selfiee-eleita-palavra-do-ano-pelo-dicionario-oxford.html>, e em: <https://languages.oup.com/word-of-the-year/>, e em: <https://www.merriam-webster.com/dictionary/selfie>. Acessos em 29 dez. 2019.
} 
FIRMINO; KANASHIRO, 2010, p. 7).

Viabilizada geralmente por uma câmera fotográfica digital embutida em um dispositivo eletrônico de telefonia móvel, a prática do selfie é hoje exercida nos mais diversos cenários urbanos e não urbanos:

Milhares, milhões de fotografias serão produzidas a partir do mesmo gesto: o braço esticado, a câmera voltada para o próprio rosto, a cidade às costas. O ato do sujeito que vai a lugares distantes e fotografa a si mesmo, ou que fotografa coisas sem nunca vê-las, é um fenômeno-chave, me parece, para entendermos o século XXI. (VIEIRA, 2018).

Usados muitas vezes para autopromoção, mas também para representatividade, os selfies são ferramentas de auto exposição que "se converteram no tipo de imagem mais produzida e exibida em todo o planeta", (SIBILIA, 2016, p. 21), e que contribuem na disputa por visibilidade entre os usuários das atuais redes sociais online ${ }^{16}$ - que são constantemente baseadas em imagens. Inclusive no Brasil, a Agência Nacional de Aviação Civil (ANAC) emitiu em 2015, um comunicado em seu site oficial permitindo o transporte do acessório conhecido como bastão de selfie ${ }^{17}$ na bagagem de mão de seus passageiros (ANAC, 2015).

De acordo com Crary (2016, p.30) "uma corrente teórica política contemporânea afirma que expor-se é uma característica constitutiva fundamental, ou trans-histórica, do indivíduo", porém, hoje, com auxílio das TICs, o indivíduo contemporâneo também produz, performa e gerencia sua própria visibilidade de maneira ativa e voluntária, - chegando a expor também sua intimidade -, muitas vezes em tempo real por meio da internet, vinte e quatro horas por dia e sete dias por semana. (BRIGHENTI, 2007; BRUNO, 2013; CRARY, 2016; BEIGUELMAN, 2016a; SIBILIA, 2016).

No filme documentário Pacific (2009), realizado no Brasil, o cineasta Marcelo Pedroso retrata, de forma bastante contundente, esta condição - de exposição intencional e

\footnotetext{
${ }^{16}$ Surgidas a partir do fim dos anos 1990 (BOYD; ELLISON, 2007), também foram chamadas de social network sites (SNSS), sites de redes sociais, (tradução nossa), por Boyd e Ellison (2007), para, segundo as próprias autoras, enfatizar justamente sua maior finalidade: que não é colocar pessoas estranhas em contato na internet - embora isso também aconteça -, e sim proporcionar conexão online entre indivíduos que já compartilham alguma conexão offline, permitindo que suas redes sociais se tornem visíveis. De acordo com o relatório Digital 2019 Global Digital Overview (Hootsuite \& We Are Social, 2019), 45\% da população mundial e 66\% da população brasileira usam SNSs, sendo que os mais populares são: Facebook, YouTube, Instagram, QZone, Douyin/TikTok, Sina Weibo, Reddit, Twitter, Douban, Linkedin, Baidu Tieba e Pinterest.

${ }^{17} \mathrm{O}$ bastão de selfie é uma haste extensora que pode ser acoplada a um smartphone com objetivo de aumentar o ângulo de abrangência dos selfies.
} 
incessante do eu -, catalisada pelas TICs. O documentário foi montado exclusivamente com registros amadores feitos por passageiros durante sete dias a bordo de um cruzeiro turístico entre Recife e Fernando de Noronha em Pernambuco. Feitas com seus dispositivos tecnológicos pessoais, são filmagens voluntárias deles próprios (passageiros turistas), e de suas famílias e amigos no cotidiano das atividades realizadas na viagem de navio, que incluem: visitas às praias, refeições, festas e entretenimento ao ar livre, entre outras situações. Sem interferir durante o percurso, ao final da viagem, a equipe do cineasta pediu aos passageiros que cedessem seus registros pessoais para realização do documentário. Ao nos apresentar esse mosaico de registros audiovisuais produzidos por um grupo específico que retrata a si mesmo, - com o qual é praticamente impossível não nos identificarmos ao menos em algumas situações -, o documentário também retrata e provoca reflexões sobre o comportamento da própria sociedade em que vivemos:

\begin{abstract}
Uma espécie de lógica dos "reality shows" triunfa, fazendo com que os personagens não se acomodem e performem sem parar. Atentos à curta duração da viagem, os turistas se veem inclinados a aproveitá-la exaustivamente. [...] o efeito implícito neste lazer cronometrado é evidente: a adesão da classe média ao labor e controle ainda que esteja de folga. (RICARDO, 2011, P.23-24)

Este navio-auditório, reserva de lazer e imaginação, mas também espaço de permanente trabalho e (auto)promoção, pode ser percebido não apenas com um navio, mas como um dispositivo ou laboratório onde performam as formas de vida hegemônicas no contexto dos novos regimes de subjetividades e visibilidade de nosso capitalismo tardio. [...] é preciso ser permanentemente interativo, participativo e colaborativo. [...] Produzir-se como um sujeito visível, nunca fora antes um trabalho tão incessante, tão inesgotável: como as aulas de aeróbica, as coreografias coletivas, as gincanas perversas, as festas temáticas [...] a ordem do dia seguida à risca em Pacific. (FELDMAN, 2011, p.9-13)
\end{abstract}

Ao tratar das condições de visibilidade entendidas enquanto regime, Bruno (2013, p. 47), baseada principalmente em Foucault (1983), nos diz que "participam máquinas, práticas, regras, discursos que estão articulados a formações de saber e jogos de poder". Desta maneira, de acordo com Brighenti (2007, p. 324, tradução nossa) ${ }^{18}$, compreendemos que "a visibilidade está na intersecção dos domínios da estética (relações de percepção) e da política (relações de poder)". O Autor ainda esclarece:

\footnotetext{
18 "Visibility lies at the intersection of the two domains of aesthetics (relations of perception) and politics (relations of power)."
} 
À medida que as tecnologias de comunicação ampliam o campo do socialmente visível, a visibilidade se torna um mercado de oferta e demanda. Em qualquer ampliação do campo, surge a questão do que vale a pena ser visto e a que preço junto com a questão normativa do que deve e do que não deve ser visto. Essas perguntas nunca são simplesmente uma questão técnica: elas são inerentemente práticas e políticas. (BRIGHENTI, 2007, p.327, tradução nossa) ${ }^{19}$

Para este autor, assim como para Bruno (2013) e Sibilia (2016), a visibilidade também pode estar fortemente ligada ao reconhecimento, pois este é uma forma de visibilidade social que gera impacto tanto em grupos marginalizados e privilegiados, quanto na relação entre eles: "para as minorias raciais e sexuais, ser invisível significa ser privado de reconhecimento", (BRIGHENTI, 2007, p.329, tradução nossa) ${ }^{20}$, o que pode levar tais populações ou indivíduos à exclusão social. Porém, ao citar como exemplo as comuns representações midiáticas de migrantes como criminosos, o autor também nos chama atenção para as ambiguidades e distorções geradas pela visibilidade e por seu gerenciamento, que podem "levar à distorções nas representações sociais", (BRIGHENTI, 2007, p.330, tradução nossa) ${ }^{21}$, pois, uma vez levadas ao extremo da supra ou super visibilidade, essas representações podem produzir o efeito contrário: como a negação do reconhecimento, por meio da generalização ou estigmatização de grupos ou populações. No entanto, com a ajuda das TICs, também se abrem possibilidades de deslocar a posição de tais minorias, - para além dos extremos da invisibilidade, onde geralmente estão situadas -, para outras posições ao longo do espectro do que é visível, como também nos mostram alguns estudos realizados em contextos periféricos brasileiros. Nestes contextos, as pesquisas apontaram o acesso às redes socias online, e à prática do selfie, como possibilidades tangíveis para a representatividade, o empoderamento e a construção Identitária de indivíduos e populações excluídos, ou estigmatizados, envolvendo locais como: o bairro Cidade de Deus, entre outros, no Rio de Janeiro; e as comunidades de Gurigica, São Benedito e Itararé, na cidade de Vitória, ES. (FREEMAN; NEMER, 2015; EVANGELISTA; POLIVANOV, 2016).

Além dos paradoxos e distorções gerados pela visibilidade, Brighenti (2007), Hatuka e

\footnotetext{
19 "As communication technologies enlarge the field of the socially visible, visibility becomes a supply and demand market. At any enlargement of the field, the question arises of what is worth being seen at which price - along with the normative question of what should and what should not be seen. These questions are never simply a technical matter: they are inherently practical and political."

20 "For racial and sexual minorities, being invisible means being deprived of recognition."

21 "lead to distortions in social representations"
} 
Toch (2017), Bruno et al. (2018) e Lyon (2018), também abordam suas assimetrias, uma vez que não é sempre que o indivíduo que vê, também está sendo visto pelo indivíduo que ele observa, (alguns podem não ter consciência de que estão sendo vistos, ou podem conseguir ver mais do que outros, ou ainda podem ser capazes de se fazer mais visíveis do que outros, ou vice-versa e assim por diante):

Dispositivos tecnológicos complexos e menos complexos, desde cortinas a muros de pedra, de câmeras de vídeo a satélites, aumentam as assimetrias de visibilidade de acordo com arranjos planejados, liberando-os das propriedades espaço-temporais do aqui e agora. (BRIGHENTI, 2007, p.327, tradução nossa) ${ }^{22}$

Para estes autores, no espaço híbrido e ampliado da cidade contemporânea, a condição ideal de reciprocidade da visibilidade tem se mostrado a exceção, enquanto que a visibilidade assimétrica tem sido normalizada. Bruno (2018, p. 241), exemplifica tal assimetria ao narrar sua visita, realizada em julho de 2015, ao Centro de Operações da Prefeitura do Rio de Janeiro - $\operatorname{COR}^{23}$, onde um técnico da instituição lhe mostrou o funcionamento de um painel georrefenciado "que visualiza, associa, minera e simula em tempo quase real", tanto dados provenientes de órgãos ligados à prefeitura da cidade do Rio de Janeiro, quanto informações provenientes das já citadas redes sociais online como Waze e Twitter:

\begin{abstract}
O técnico seleciona um tema qualquer, de sua escolha - no caso, "acidente" -, e na barra esquerda da tela, ao lado da imagem-satélite da região selecionada, visualizamos todas as postagens que tinham partido de dispositivos com geolocalização ativa no local, contendo a palavra "acidente". [...] 0 indivíduo que está "tuitando" algo na região monitorada pelo COR torna-se especialmente visível para essa instituição. Ao mesmo tempo, tal sobrevisão é bastante opaca para ele, a ponto de nem sequer saber desse rastreamento e, ainda que soubesse, não ter meios de negociar nem de controlar os seus efeitos. (BRUNO, 2018, p. 244).
\end{abstract}

De acordo com a situação descrita pela autora, fica claro que no espaço híbrido e ampliado da cidade contemporânea - neste caso, nos territórios monitorados pelo COR, no Rio de Janeiro -, os cidadãos usuários das redes sociais online, se encontram em condição

\footnotetext{
22 "Complex and less complex technological devices, from curtains to stone walls, from vídeo cameras to satellites, enhance visibility asymmetries according to planned arrangements, liberating it from the spatialtemporal properties of the here and now"

23 "Inaugurado em 2010 pela prefeitura do Rio de Janeiro, em parceria com a IBM, o COR surge com o objetivo de fazer do Rio uma cidade inteligente (smart city) de ponta, tendo como laboratório os grandes eventos que a cidade sediaria, especialmente a Copa do Mundo FIFA em 2014 e os Jogos Olímpicos em 2016." (BRUNO, 2018, p. 240). Site oficial disponível em: <http://cor.rio/>. Acesso em: 28 nov. 2019.
} 
assimétrica de visibilidade, pois, embora estejam sendo monitorados pelo governo e seus parceiros, nem sempre possuem consciência sobre o quanto estão tornando visível, nem sobre quando, onde, ou quem exatamente os está vendo ou vigiando (BRUNO, 2018). 


\section{CAPÍTULO II - VIGILÂNCIA, OLHAR E INFORMAÇÃO}

\subsection{A relação entre visibilidade, compartilhamento de dados e vigilância}

A pesquisa TIC Domicílios 2018, (COMITÊ GESTOR DA INTERNET NO BRASIL, 2018, p. 103), que trata sobre o uso das Tecnologias de Informação e Comunicação em domicílios do país, apontou, no último ano, que "um terço (32\%) dos usuários de Internet brasileiros pediu táxis, ou serviço de transporte em aplicativos, o que representa 40,8 milhões de pessoas". A partir de informações como esta, podemos entender que: a maneira como cada vez mais pessoas passam a apreender, e se deslocar, no espaço urbano, por meio de aplicativos para dispositivos móveis que interferem diretamente na mobilidade - como Waze, Google Maps ${ }^{24}$, ou Uber ${ }^{25}$ entre outros -; é também mais um indício de como as TICs impactam nos espaços em que vivemos e em nossas práticas cotidianas, neste caso, em especial, na reorganização da mobilidade que está em curso em nossas cidades. Porém, diante da nossa condição de visibilidade atual, em que sua assimetria tem se normalizado, e que nossos dados tem sido capturados, muitas vezes sem nos darmos conta (BRIGHENTI, 2007; HATUKA; TOCH, 2017; BRUNO et al., 2018; LYON, 2018; ZUBOFF, 2018), - como exemplificado na descrição feita por Bruno (2018), sobre a maneira de atuação do COR no Rio de Janeiro, ao final do subcapítulo anterior -, fica claro que ao utilizarmos tais aplicativos online, que através de GPS

\footnotetext{
${ }^{24}$ O Google Maps assim como o já citado Waze, também é um aplicativo para dispositivos móveis, baseado em navegação por satélite, que disponibiliza mapas e rotas de trânsito e permite o compartilhamento de informações via internet a respeito da localização de seus usuários. De acordo com dados divulgados em seu site oficial, atualmente, o Google Maps possui mais de um bilhão de usuários ativos por mês espalhados em mais de 200 países e territórios ao redor do mundo. Informações disponíveis em seu website oficial: $<$ https://cloud.google.com/maps-

platform/?hl=pt\&utm_source=google\&utm_medium=cpc\&utm_campaign=FY18-Q2-global-demandgen-

paidsearchonnetworkhouseads-cs-maps_contactsal_saf\&utm_content=text-ad-none-none-DEV_cCRE_320067022502-ADGP_Hybrid+\%7C+AW+SEM+\%7C+BKWS+ +Google+Maps-KWID_43700039700584748kwd-21146297871-userloc_1001773\&utm_term=KW_\%2Bgoogle\%20\%2Bmaps-

T_\%2Bgoogle+\%2Bmaps\&gclid=EAlalQobChMltaq_zYPr5gIVkAyRCh1C5AhSEAAYASAAEgJelPD_BwE >. Acesso em: 04 jan. 2020.

${ }^{25}$ Uber é um aplicativo para serviços de transporte semelhante ao táxi, que funciona por meio de uma plataforma online que permite conectar passageiros e motoristas em tempo real com base na localização de ambos por meio de GPS. Segundo o site oficial da empresa, o aplicativo hoje funciona em mais de cem cidades no Brasil, e possui mais de três milhões de motoristas cadastrados, e noventa e três milhões de usuários, distribuídos em mais de 60 países e setecentas cidades ao redor do mundo, sendo que, destes, mais de seiscentos mil motoristas cadastrados e vinte e dois milhões de usuários estão no Brasil. Informações disponíveis em seus canais oficiais na internet: <https://www.uber.com/pt-BR/blog/o-que-e-uber/>, e em: <https://www.uber.com/ptBR/newsroom/fatos-e-dados-sobre-uber/>. Acessos em: 06 jan. 2020.
} 
(tecnologia de localização por satélite) registram os lugares pelos quais passamos, podemos também estar contribuindo com um tipo específico de vigilância.

Chamada por Bruno (2013) de vigilância distribuída e tratada por Lemos (2010), Koskella (2010) e Virilio (2012) como nova vigilância ou vigilância atual, contemporânea, em que muitos vigiam muitos, é aquela que é espraiada, heterogênea, diversificada e se caracteriza por seu caráter reticular - em rede. De acordo com Virilio (2012), diferente da vigilância do século XIX, que dependia do sujeito encarcerado, preso, sob a vigilância do cárcere, a vigilância atual depende de um estado de ocupação permanente. Esse sujeito contemporâneo, ocupado, atuante, produz registros físicos e digitais de suas atividades e consequentemente deixa rastros, (informações passíveis de serem monitoradas) principalmente online. Por exemplo, segundo Bioni e Machado (2016), desde que o programa Nota Fiscal Paulista foi implantado, ao informar seu CPF no ato da compra, em um estabelecimento comercial das cidades brasileiras participantes do programa, corre-se o risco de compartilhar com o Estado, - e com as empresas para as quais ele cede seus dados -, o nosso perfil de compras e a lista de lugares que costumamos frequentar. Esta também seria uma maneira de contribuirmos com a vigilância distribuída. A pesquisa de Bioni e Machado (2016) será apresentada de maneira mais ampla a seguir no desenvolvimento do presente trabalho.

Bruno (2013) atualiza os conceitos de Foucault (1983), e define o conceito de vigilância em que esta pesquisa se baseia:

[...] em linhas gerais, uma atividade de vigilância pode ser definida como a observação sistemática e focalizada de indivíduos, populações ou informações relativas a eles, tendo em vista produzir conhecimento e intervir sobre os mesmos, de modo a conduzir suas condutas. Esta definição, de caráter mais amplo, precisa, contudo, ser complementada com a descrição das particularidades contemporâneas da vigilância distribuída [...] As atuais práticas de vigilância contam com uma imensa e crescente diversidade de tecnologias, discursos, medidas legais e administrativas, instituições e corporações, enunciados e empreendimentos científicos, midiáticos, comerciais, políticos etc. Tais elementos não são apenas diversos, mas também distribuídos. Muitos deles só podem ser definidos, quanto às suas propriedades vigilantes, pelas relações que mantêm uns com os outros, e não por suas características intrínsecas, sendo portanto constituídos pelas redes segundo as quais se articulam. (BRUNO, 2013, p. 18-19)

Vale esclarecer a diferença entre ver e vigiar, ou entre vigilância e visibilidade, de acordo com Bruno (2013), se não houver a intenção de intervir sobre os indivíduos ou 
populações em foco, não se trata de vigilância, e sim de práticas de visibilidade. O ver, o ser visto, ou a exposição pessoal são práticas de visibilidade.

No subcapítulo anterior também abordamos a popularização dos selfies, e a condição atual de produção incessante da própria visibilidade por parte de inúmeros indivíduos, com os mais diversos propósitos, como autopromoção, construção de identidades, reconhecimento e representatividade, entre outros (BRIGHENTI, 2007; BRUNO, 2013; FREEMAN; NEMER, 2015; CRARY, 2016; BEIGUELMAN, 2016a; EVANGELISTA; POLIVANOV, 2016; SIBILIA, 2016; HATUKA; TOCH, 2017; VIEIRA, 2018). Porém, entendemos que ao usarmos a internet para postar nossos registros fotográficos, - que muitas vezes contém informações dos lugares por onde passamos -, também poderíamos estar contribuindo com a vigilância distribuída, o que faz com que espaços de compartilhamento de dados, visibilidade e/ou exposição de pessoas, também se tornem potenciais espaços de vigilância (BRIGHENTI, 2007; HATUKA; TOCH, 2017; BRUNO et al., 2018).

De acordo com Bruno (2013), mais uma vez baseada em Foucalt (1983), são dois os elementos-chave dos processos de vigilância: o olhar e as informações sobre o que se vigia. A autora defende que atualmente as TICs contribuíram não só para o aumento da visibilidade dos indivíduos (como enfatizamos ao longo deste capítulo), mas também contribuíram para o aumento, e produção, das informações que se tem sobre eles, (principalmente porque as TICs suscitam o compartilhamento de dados na internet, e por que permitem rastreamentos digitais e produção de novos dados a partir dos mais diversos registros deixados pelos usuários no ciberespaço). Ao figurar no campo da visibilidade e no campo da informação (ou do compartilhamento de dados), o indivíduo se torna o próprio objeto da vigilância, que implica não apenas sua observação, "mas a produção de um saber que permita governar as suas condutas". (BRUNO, 2013, p.145).

Rodriguez (2018, p. 196) afirma que "na atualidade os indivíduos se manifestam e concordam em gerar amplas visibilidades de suas próprias vidas e, com isso, se oferecem a uma vigilância inédita em relação aos tempos disciplinares". A este respeito, é importante enfatizarmos que, como mostramos no subcapítulo anterior, muitas vezes as pessoas nem sequer sabem que estão sendo monitoradas ou que estão compartilhando determinados dados a respeito de si próprias. Dito de outra forma: embora via de regra, a adesão à visibilidade, ou à grande parte dela, seja voluntária, e chegue até a ser desejada por um grande número de pessoas; a adesão à vigilância, normalmente não é. (BRIGHENTI, 2007; HATUKA; 
TOCH, 2017; BRUNO et al., 2018). Ocorre que, em muitas situações, diante da necessidade de usar determinado serviço, não é permitido ao indivíduo optar por não ceder seus dados. Ou quando há a opção do usuário negar a entrega de determinados dados, o acesso ao serviço geralmente é dificultado (ZUBOFF, 2018; AVELINO; SILVEIRA; SOUZA, 2018), conforme exemplificaremos a seguir.

Atualmente, a Secretaria Municipal de Mobilidade e Transportes da Prefeitura de São Paulo - SPTrans já emprega amplamente o sistema de reconhecimento facial no transporte público da cidade. O início da implantação do sistema se deu há aproximadamente cinco anos, com propósito inicial de tornar o embarque dos passageiros mais ágil e eficiente, e posteriormente, à medida que o sistema foi sendo aperfeiçoado, também com propósito de evitar fraudes. Os bilhetes eletrônicos de acesso ao transporte da rede pública da cidade também já chegaram a ser emitidos pela SPTrans com a foto impressa de seu usuário, medida que foi cancelada posteriormente (PREFEITURA DE SÃO PAULO, 2015; VENTURA, 2015b; MOREIRA, 2019a). E desde junho de 2018, devido a um aumento significativo no número de fraudes relacionadas à falsificação de créditos, e ao uso indevido dos bilhetes no último ano, a SPTrans além de deixar de comercializar bilhetes eletrônicos sem identificação, também instituiu que todos os usuários que ainda não possuíssem bilhete personalizado (com cadastro obrigatório, nome e CPF impressos), seriam obrigados a se cadastrar no site da instituição, e retirar seu novo bilhete que atenda aos requisitos atuais até 30/09/2019. Caso contrário, embora não houvesse bloqueio dos bilhetes não personalizados, suas novas recargas de créditos não poderiam mais ultrapassar o limite de quarenta e três reais (ZAVRICK, 2019a, 2019b) ${ }^{26}$. Com o custo da passagem de ônibus hoje a quatro reais e trinta centavos, o usuário que opta por não ceder seus dados, e gasta uma passagem de ida e outra de volta por dia útil para trabalhar, por exemplo, teria que recarregar seu bilhete, - e perder seu tempo em filas para isso -, no mínimo uma vez por semana, enquanto que quem opta por realizar o cadastro, e ceder ainda mais dados, pode continuar com limite de recarga de créditos de trezentos e cinquenta reais - e se dar ao direito de enfrentar filas para recargar seu bilhete menos vezes na sua rotina. Neste exemplo o acesso ao serviço é claramente dificultado para quem escolhe não ceder - ou ceder menos de - seus dados.

Também é importante destacarmos que a visibilidade não está necessariamente ligada

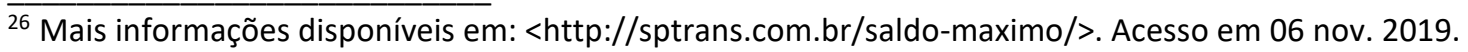


de maneira direta ao monitoramento, ou à vigilância, - nem à autopromoção, ou ao reconhecimento -, todas estas implicações e desdobramentos fazem parte de sua condição multifacetada, que investigamos, no presente trabalho, ao estendermos a noção de visibilidade para o campo sociológico (BRIGHENTI, 2007; BRUNO, 2013; SIBILIA, 2016; HATUKA; TOCH, 2017; LYON, 2018). Entretanto, também foi possível observar, ao longo deste capítulo, que: a) A visibilidade assimétrica está sendo normalizada (por compartilharmos nossos dados de maneira incessante, por meio de inúmeros dispositivos tecnológicos que carregamos conosco ou que estão instalados nos mais diversos espaços urbanos. Isso faz com que seja aceita sem questionamento, por sequer ser percebida, ou por ser de difícil recusa, entre outros motivos); b) É justamente esta condição de assimetria que torna difícil a identificação da vigilância. Assim, entendemos que quando alguém se encontra em posição assimétrica de visibilidade, (na condição de ver menos do que - ou não ver - o outro que te olha), fica mais difícil identificar ou recusar a vigilância. Dito de outra forma: se a visibilidade assimétrica está sendo normalizada, devemos nos preocupar mais com a presença crescente e o emprego das TICs em nossas cidades, porque é principalmente na sua condição assimétrica que a visibilidade facilita a vigilância. (BRIGHENTI, 2007; VIRILIO, 2012; HATUKA; TOCH, 2017; AVELINO; SILVEIRA; SOUZA, 2018; BRUNO et al, 2018; ZUBOFF, 2018). 


\subsection{Vigilância e reconhecimento facial em espaços públicos urbanos}

Conforme temos mostrado no presente trabalho, de acordo com Brighenti (2007), Hatuka e Toch (2017) entre outros autores, mas, neste caso especialmente, segundo Bruno, Firmino e Kanashiro (2010), as margens do visível, os modos de fazer ver, e os modos de ser visto estão sendo ampliados e modificados nas sociedades contemporâneas. Assim como também se ampliam e se modificam os dispositivos e práticas da vigilância:

\footnotetext{
Esta reorganização dos modos de ver e de ser visto, envolve, num mesmo movimento, os dispositivos de vigilância, os quais são cada vez mais diversos em suas técnicas, modos de atuação e significados. A experiência e a presença, atual ou potencial, de tecnologias e procedimentos de vigilância tornaram-se cada vez mais corriqueiras nas arquiteturas urbanas, nos meios de comunicação, nas formas de deslocamento pelo espaço físico e informacional. (BRUNO; FIRMINO; KANASHIRO, 2010, p. 7)
}

Além disso, vimos no capítulo anterior que as pessoas podem nem se dar conta da vigilância, ou podem encontrar dificuldades para não se submeterem a ela. Porém, Bruno (2013) afirma que um, ou mais indivíduos, também podem exercer a vigilância de maneira consciente, com foco na vida comum de outra pessoa, ou ainda podem ser convocados por outros agentes - e aceitar o convite -, a participar ativamente da vigilância com foco em grupos específicos. Para exemplificar esta última situação, a autora cita o caso de um programa de vigilância civil voluntária, intitulado: "Programa de Observação Virtual da Fronteira do Texas" (BRUNO, 2013, p.134, tradução nossa) ${ }^{27}$, que foi desenvolvido pelo governo norte americano em parceria com uma empresa privada. Trata-se de uma plataforma online, que orientou a participação de pessoas para o monitoramento de espaços urbanos, convidando-as a atuarem como vigias colaborativos da fronteira entre México e Estados Unidos, de maneira remota, por meio da internet, durante os anos de 2008 a 2012 (BRUNO, 2013). O caso foi objeto de diversos estudos, destacamos entre eles o trabalho da pesquisadora Hille Koskela (afiliada à Universidade de Turku, na Finlândia), que chegou a ser traduzido para o português, e o trabalho desenvolvido pela artista espanhola Joana Moll em parceria com o antropólogo francês Cédric Parizot. Estes dois últimos pesquisadores acompanharam durante os anos de 2010 a 2013 as atividades de um grupo de indivíduos no

\footnotetext{
27 "Texas Virtual Border Watch Program" (tradução nossa)
} 
Facebook $^{28}$, constituído de maneira espontânea, em sua maioria por civis americanos com perfis públicos, que participavam do programa e vigiavam voluntariamente trechos ao longo da fronteira entre México e Estados Unidos através de duzentas câmeras em circuito fechado de televisão ${ }^{29}$.

Segundo Moll e Parizot (2016), os vigilantes voluntários podiam acessar gratuitamente as transmissões das câmeras em seus computadores pessoais, por meio de um website disponibilizado em 2008 pelo governo dos Estados Unidos em parceria com a empresa BlueServo ${ }^{30}$, que pertencia ao Programa de Observação Virtual da Fronteira do Texas. 0 objetivo declarado da iniciativa era levar os cidadãos americanos a participar na redução do crime fronteiriço por meio de crowdsourcing ${ }^{31}$. Seu site transmitia 24 horas por dia e 7 dias por semana, e permitia que seus usuários informassem anonimamente se percebessem atividades suspeitas nos locais de monitoramento. A plataforma on-line de vigilância chegou a ter mais de 200 mil usuários voluntários, e resultou em mais de 5 mil interdições, que correspondeu a quase 1 milhão de horas de trabalho gratuito para as autoridades. (MOLL; PARIZOT, 2016). A artista Joana Moll se inscreveu no programa com uma identidade falsa, foi aceita no grupo de vigilantes voluntários do Facebook e narrou sua experiência:

\begin{abstract}
Mesmo que eu estivesse moralmente contra os propósitos do site, quando algo se movesse, ou a atividade humana pudesse aparecer, eu sentia necessidade de pressionar o botão vermelho. Uma vez imersa na lógica - e, por extensão - às regras do site, sentia-me como a coisa certa a fazer. Refletir não parecia ser uma opção, pelo menos não antes de tomar uma ação. A interface, juntamente com os feeds da câmera, permitiu a descontextualização física da fronteira ao trazê-la para a esfera privada do usuário na forma de um jogo, além disso, o site se assemelhava a um
\end{abstract}

\footnotetext{
${ }_{28}$ De acordo com o relatório Digital 2019 Global Digital Overview (Hootsuite \& We Are Social, 2019), o Facebook é atualmente a rede social que mais tem contas ativas de usuários no mundo (mais de um bilhão de inscritos) e é a terceira mais visitada do planeta. Canais de mídia e imprensa brasileiros noticiaram em 2018 e 2019 que a sua quantidade de usuários brasileiros passava de 100 milhões. Informações disponíveis em: <https://datareportal.com/reports/digital-2019-global-digital-overview>, e em: <https://www1.folha.uol.com.br/tec/2018/07/facebook-chega-a-127-milhoes-de-usuarios-mensais-nobrasil.shtml>, e em: <https://noticias.r7.com/tecnologia-e-ciencia/brasil-e-o-3-pais-com-o-maior-numero-deusuarios-do-facebook-02032019>, e em: <https://www.oficinadanet.com.br/midias_sociais/26638-os-10paises-que-mais-acessam-o-facebook-no-mundo> Acessos em: 06 jan. 2019.

${ }^{29}$ Constituído basicamente por câmeras, meios de transmissão e monitores, o circuito fechado de televisão é aquele cujos sinais provenientes de câmeras não são transmitidos abertamente. Sua transmissão é destinada apenas a um ou mais pontos de visualização específicos.

${ }^{30} \mathrm{O}$ site oficial da empresa está disponível em: <http://blueservo.com/>. Acesso em: 14 jan. 2020.

${ }^{31}$ Conceito de língua inglesa que se originou dos termos crowd (multidão) e outsourcing (que alude à terceirização de serviços ou recursos). Crowdsourcing é um modelo de atividade de desenvolvimento, criação e/ou produção, por meio de mão-de-obra e conhecimento coletivos.
} 
videogame, onde qualquer ação tomada seria sem consequência. (MOLL; PARIZOT, 2016, tradução nossa) ${ }^{32}$

A descontextualização física da fronteira, que suprime o espaço-tempo do pensar de que trata os autores também podem ser observadas nas reflexões de Virilio (2012), que afirma que o espaço real da geografia está conectado com o tempo real da ação humana. O autor defende que a perda de lugar é acompanhada pela perda do corpo e que por isso as pessoas são obrigadas a transferir seu poder de decisão para respostas automáticas. À medida que as TICs viabilizaram fenômenos de interação instantânea, que resultaram em uma supressão do tempo reservado para a reflexão, em favor de respostas condicionadas produzidas pela emoção, podem provocar uma desestabilização na relação das interações humanas (VIRILIO, 2012). Em sua análise sobre o Programa de Observação Virtual da Fronteira do Texas, Koskella (2010, p.184) argumenta que embora o objetivo oficialmente declarado pelas autoridades dessa iniciativa era de que o projeto não havia sido criado para controlar a imigração, mas na prática ele acabava por fazê-lo de uma maneira perversa, uma vez que nele "a vigilância é usada para lidar com o medo ligado a uma população vista como diferente ou desviante: os vindos do Sul, os mexicanos, os ilegais, os sem documentos, os indesejados, os pobres. Vigilância é, assim, usada para gerir e forçar a exclusão". Neste sentido, observa-se que a segurança é usada para justificar o emprego de sistemas tecnológicos de vigilância, que acabam por gerar exclusão social em territórios urbanos.

Segundo Moll e Parizot (2016, tradução nossa) 33, "o programa foi encerrado em 2012 devido à falta de apoio financeiro, conforme anunciado em sua página oficial do Facebook em 13 de maio de $2012 " 34$. E sofreu também, entre outras críticas, questionamentos a respeito de sua real eficiência:

\footnotetext{
32 "Even though I was morally against the purposes of the site, when something would move, or human activity would appear, I felt compelled to press the red button. Once immersed in the logic - and by extension - the rules of the site, it felt like the right thing to do. To reflect did not seem to be an option, at least before taking an action. The interface, along with the camera feeds, allowed to physically decontextualize the border and bring it to the user's private sphere in the shape of a game, moreover, the site resembled a video game, where any action taken would be without consequence".

33 "The programme ended in 2012 due to, as announced on its official Facebook page in May 13 2012, lack of financial support".

${ }^{34}$ Durante o desenvolvimento deste trabalho, uma página de um grupo público com quase 200 membros no Facebook, intitulada: Texas Border Watchers BlueServo ainda se encontrava no ar, com seu feed de notícias aberto ao público. Disponível em: <https://www.facebook.com/groups/2217025407/>. Acesso em: 18 jan. 2020.
} 
Passando pelas conversas, notava-se rapidamente a dificuldade que os usuários do RedServant tinham em usar a plataforma ou até mesmo identificar o que estavam realmente assistindo. Em muitos casos, eles confundiram animais com pessoas e relataram a presença de cidadãos americanos ao longo da fronteira. Dada a quantidade de participantes, pode-se esperar que o sistema tenha entrado em colapso em parte porque, com esses erros, os usuários podem ter desviado a atenção da polícia ou até saturado a plataforma RedServant do xerife. De fato, alguns dos xerifes que participaram do programa afirmaram publicamente que o RedServant era, na melhor das hipóteses, ineficiente e, na pior, um desperdício de dinheiro. (MOLL; PARIZOT, 2016, tradução nossa) ${ }^{35}$

Embora o Programa de Observação Virtual da Fronteira do Texas não se encontre mais ativo, seu local de enfoque continua sendo uma área de disputas e tensões territoriais, e de 2012 para cá outros programas com propósitos similares, como a redução de crimes na fronteira, tem sido idealizados pelas autoridades americanas aliadas a empresas privadas, tendo como base principal o uso das TICs, - passando por construções de muros virtuais ou inteligentes até propostas de emprego de drones no local -, como as que foram noticiadas entre final de 2018 e meados de 2019, (METZ, 2018; CHARPENTRAT; LEVER, 2019; SHANKLAND, 2019; DAVIS, 2019). Nos resta saber se tais programas continuarão a contribuir para situações de exclusão social de maneira perversa, ou se a tecnologia será desenvolvida e empregada também para romper com lógicas sociais excludentes já existentes em nossos territórios urbanos.

A territorialização da vigilância - com adesão voluntária ou por coerção - foi explicitada principalmente em situações como a atividade do COR no Rio de Janeiro, e como a implantação do Programa de Observação Virtual da Fronteira do Texas, nos Estados Unidos, que foram citados no presente trabalho. Além desses casos, há ainda um outro caso no Brasil que destacaremos a seguir. Nesta situação, que ocorreu recentemente na cidade de São Paulo, um dispositivo foi construído para captura de dados pessoais - entre outros propósitos, para serem usados em marketing direcionado -, também envolveu um grande número de pessoas em espaços públicos, e gerou discussão sobre o direito à privacidade, e sobre o uso de dados de cidadãos por parte de uma empresa privada, aliada ao poder público brasileiro.

\footnotetext{
35 "Going through the conversations, one would quickly notice the difficulty that RedServant users had in using the platform or even identifying what they were actually watching. In many cases, they mistook animals for people and reported the presence of US citizens along the border. Given the amount of participants one can expect that the system collapsed in part because, through these mistakes, users might have diverted the attention of the police or even saturated the RedServant platform of the Sheriff. Indeed, some of the Sheriffs that took part in the programme publicly claimed that RedServant was at best inefficient and at worst a waste of money."
} 
Trata-se do sistema de reconhecimento facial que foi implantado e permaneceu em funcionamento parcial por curto período - por volta de abril a agosto de 2018 - inicialmente nas estações: Luz, Paulista e Pinheiros da Linha 4-Amarela do metrô. Na ocasião, assim como diversos canais da imprensa brasileira (CRISTINA, 2018; MARCHETTI, 2018; UOL 2018), a concessionária ViaQuatro (responsável pela operação e manutenção da Linha 4-Amarela do metrô), também noticiou por meio de seu website oficial, o lançamento do sistema e descreveu brevemente seu funcionamento, conforme apresentaremos a seguir.

Através dos dispositivos e sistemas tecnológicos implantados nas estações, os usuários do metrô supostamente tiveram suas expressões e imagens faciais capturadas ao assistirem anúncios comerciais ou institucionais que foram transmitidos em monitores instalados ao lado das portas de acesso dos vagões de trens. A tecnologia utilizada identifica a presença humana pelas formas dos rostos e corpos, sugere a classificação pessoal em gênero masculino ou feminino, estima se o indivíduo é criança, jovem ou adulto, e interpreta, por meio de algoritmos em seu software, algumas expressões faciais, que são classificadas em quatro tipos de emoções sugeridas: feliz, insatisfeito, surpreso e neutro. (VIAQUATRO, 2018; AFFONSO, 2018a; ELER, 2018).

A partir destas informações diversos aspectos podem ser debatidos, mas, vamos nos deter sobre dois deles, sendo o primeiro relacionado a privacidade dos usuários do metrô e às finalidades deste sistema de reconhecimento facial, e o segundo relacionado à possível discriminação de gênero e de populações estigmatizadas.

Sobre o primeiro aspecto, questiona-se: quem tem acesso aos dados capturados dos usuários do metrô? Para que serão usados? Em resposta a um artigo de Carlos Affonso (diretor do Instituto de Tecnologia e Sociedade - ITS Rio, e professor da Faculdade de Direito da Universidade do Estado do Rio de Janeiro), publicado em abril de $2018 \mathrm{em}$ seu blog Tecfront, a ViaQuatro alegou que: "A tecnologia não faz recolhimento de dados dos passageiros, nem reconhecimento de identificação pessoal. Além disso, a tecnologia não grava, armazena imagens ou faz cruzamento de dados do indivíduo, uma vez que não tem informações para isso." (AFFONSO, 2018a). Já a explicação do próprio presidente da ViaQuatro, publicada no mesmo mês, no site oficial da concessionária, sobre o assunto dizia que: 
sofisticados, pode colaborar na criação de novas estratégias para públicos específicos, visando mais efetividade na troca de mensagens importantes ou mesmo o incremento em vendas, explica Harald Zwetkoff, presidente da ViaQuatro. (VIAQUATRO, 2018)

Ao analisarmos tais declarações, mais questionamentos são levantados: se a tecnologia citada, não recolhe nem cruza dados dos passageiros; não faz reconhecimento de identificação pessoal; e não grava nem armazena imagens de indivíduos; como ela poderia: aprimorar a transmissão de informações aos passageiros da Linha 4-Amarela? Ser uma nova ferramenta na área de comunicação e marketing? Colaborar na criação de novas estratégias para públicos específicos? Visar o incremento de vendas e mais efetividade na troca de mensagens importantes? Em outras palavras, pergunta-se: como esta tecnologia poderia atingir tamanha efetividade em comunicação e marketing direcionado sem reter um único dado, ou sem uma única análise de dados - cruzados ou não - de feedback dos usuários? As respostas a essas perguntas são no mínimo contraditórias, e evidenciam a falta de transparência, por parte da empresa e dos órgãos públicos responsáveis, tanto para esclarecer sobre a coleta, propriedade, uso e compartilhamento dos dados dos cidadãos, quanto para elucidar sobre qual era a finalidade ou propósito real da iniciativa. A Concessionária que administra a Linha 4-Amarela foi alvo de ação civil pública, pela operação do sistema de reconhecimento facial, resultando na determinação do Tribunal de Justiça de São Paulo para que os sensores que fazem o reconhecimento facial dos passageiros nas plataformas fossem desativados (CONVERGENCIA DIGITAL, 2018; ELER, 2018; FARIAS, 2018; G1, 2018c; PELEGI, 2018). A alegação da ação civil era de que a coleta, e venda dos dados capturados dos usuários do metrô para possíveis anunciantes, sem o consentimento expresso dos próprios usuários, era ilegal. Além disso, caso algum usuário da Linha 4-Amarela não quisesse ter suas informações coletadas, seria obrigado a usar outro meio de transporte para se locomover na cidade. Nesta situação, mais uma vez podemos observar que, caso o cidadão opte por não se submeter a vigilância, ele praticamente fica sem opções viáveis.

Ainda sobre o assunto relacionado à privacidade dos usuários no caso do metrô, Foletto e Rolnik (2019) discorrem: controlados, impedindo, na prática, o anonimato e a privacidade. Ora, justamente o anonimato e a privacidade da metrópole foram a grande transformação dos modos de vida, permitindo pela primeira vez uma vida sem os controles sócio-políticos das 
pequenas comunidades. Este foi o grande tema dos sociólogos da vida urbana na virada do século 19 para o século 20, quando o fenômeno da grande cidade emergiu como uma ruptura - libertadora - dos modos de organização sócio territoriais anteriores. Andar pelas ruas, calçadas e espaços públicos de uma cidade sem ser identificado é uma conquista tornada possível com a urbanização em grande escala: se misturar à massa de pessoas sem ter sua identidade definida e rastreada faz parte do direito ao anonimato e à propriedade que cada um tem de seu corpo e movimentos. O que, constituiu em sua gênese, um dos fundamentos da democracia. (FOLETTO; ROLNIK, 2019).

Da mesma maneira, Silveira (2017) também concorda que a privacidade - cujo direito é assegurado aos cidadãos brasileiros na Constituição Federal da República de 1988 -, é essencial para as democracias, e recentemente, o sancionamento da Lei Geral de Proteção de Dados Pessoais (LGPD) no Brasil, contribui nesse sentido (BRASIL, 2018b). A Lei passará a vigorar no país a partir de agosto de 2020, e de acordo com o terceiro parágrafo do artigo 11, a comunicação ou uso compartilhado de dados pessoais sensíveis com objetivo de vantagem econômica, sem a autorização do indivíduo de quem os dados foram coletados, - como ocorreu no caso da linha 4-amarela do metrô de São Paulo -, poderá ser vedado pelas autoridades nacionais. Até o presente momento, a ViaQuatro está acatando a determinação do Tribunal de Justiça de São Paulo, e mantém o referido sistema de reconhecimento facial desativado. Porém, a Companhia do Metropolitano de São Paulo publicou em 28/06/2019 no Diário Oficial do Estado, uma nova licitação para implantação de um outro sistema de monitoração eletrônica, desta vez nas linhas 1-Azul, 2-Verde e 3-Vermelha do metrô da cidade, que inclui também entre outras medidas o reconhecimento facial de seus usuários (COMPANHIA DO METROPOLITANO DE SÃO PAULO, 2019). Uma das principais diferenças que podemos observar, deste, em comparação ao sistema que foi desativado da linha 4-Amarela está na finalidade. De acordo com o Metrô, o novo sistema tem como propósito melhorar a segurança no transporte, - e não o incremento de vendas nas áreas de comunicação de marketing. Embora, a finalidade declarada do novo sistema não seja o lucro, Foletto e Rolnik (2019) alertam que possíveis brechas na legislação podem permitir que os dados coletados também sejam vendidos à anunciantes do Metrô, - inclusive o Ministério Público do Distrito Federal e Territórios abriu um inquérito em setembro de 2019 para investigar empresas que vendem reconhecimento facial no Brasil, com enfoque em suas fontes e propósitos (VENTURA, 2018). Além disso, os autores também chamam a atenção para o fato de que já existem outras cidades, principalmente nos Estados Unidos, - como: São Francisco, Somerville 
e Oakland, -, que estão proibindo amplamente o reconhecimento facial em seus espaços públicos (FABIO, 2019; METZ, 2019), em defesa ao direito à privacidade.

Sobre o segundo e último aspecto que vamos nos deter, ainda a respeito do sistema da ViaQuatro que foi desativado, cabe a pergunta: se no sistema de reconhecimento facial da Linha 4-Amarela do metrô de São Paulo, é sugerido a classificação pessoal em gênero masculino ou feminino, como se classificariam as pessoas que optam por uma definição não binária de seus gêneros? Essa questão simples evidencia um possível aspecto excludente deste sistema. Seguindo por esta lógica, não haveria espaço adequado para estas pessoas expressarem seu feedback sobre os anúncios ou serviços prestados pelo metrô, ou provavelmente correriam maior risco de terem seus feedbacks classificados de maneira equivocada.

Em 2014, Steven Talley, civil americano, chegou a ser preso duas vezes e teve sua vida arruinada por causa de erros da divisão do FBI que trabalhava com análise de reconhecimento facial na época. Imprecisões do sistema o levaram a ser confundido com assaltantes de bancos na cidade de Denver nos Estados Unidos (SCHREDER, 2018) ${ }^{36}$. Em 2015 canais de imprensa nacionais e internacionais noticiaram que um algoritmo do Google classificou pessoas de descendência afro-americanas como gorilas (DOUGHERTY, 2015; KASPERKEVIC, 2015; ZHANG, 2015; SALAS, 2018). Com cada vez mais frequência, pesquisas recentes apontam para a discriminação racial e de gênero em algoritmos, - revelando que sua suposta neutralidade é geralmente equivocada -, e também abordam as origens das práticas de exclusão presentes nas tecnologias ao discutirem os vieses perpetuados por seus desenvolvedores, em sua maioria homens, heterossexuais, brancos, e de países considerados mais desenvolvidos (BROWNE, 2015; BUOLAMWINI; GEBRU, 2018; KEYES, 2018; BENJAMIN, 2019).

Buolamwini e Gebru (2018) afirmam que nos sistemas de classificação algorítmicas que estudaram, a assertividade foi maior para pessoas brancas do sexo masculino e menor para pessoas negras do sexo feminino. Keyes (2018), em sua pesquisa sobre a história do reconhecimento facial, também nos mostra que a tecnologia não é neutra, pois depende

\footnotetext{
${ }^{36}$ O caso foi narrado no episódio 3, intitulado: "Face Value" - (Valor de Face, em tradução nossa) - na segunda temporada do Podcast IRL, da empresa Mozilla sediada na Califórnia, Estados Unidos. No mesmo episódio o artista Adam Harvey revela como preconceitos raciais encontram-se infiltrados em grandes conjuntos de dados. De acordo com a descrição do site official do IRL, o mesmo é dedicado principalmente a discutir problemas de práticas on-line que podem afetar as pessoas, como notícias falsas, violações de privacidade entre outras. 0 episódio se encontra disponível em: <https://irlpodcast.org/season2/episode3/>. Acesso em: 22 fev. 2019.
} 
fundamentalmente da visão e dos vieses de quem está por trás de seu desenvolvimento. 0 autor demonstra que as pessoas transgêneros são historicamente excluídas, e de maneira sistêmica, das operações algorítmicas de um subcampo do reconhecimento facial, chamado “Reconhecimento Automático de Gênero" (KEYES, 2018, p.88.1, tradução nossa) ${ }^{37}$, que não é capaz de classificar, ou reconhecer, esses indivíduos com precisão. O que pode implicar sérios problemas (como riscos de hostilidade, rejeição e agressão), quando a tecnologia é empregada principalmente em espaços que normalmente possuem orientação de uso apenas para pessoas de gêneros binários, como no caso de controle de acessos a banheiros de empresas, estabelecimentos comerciais ou de uso público, por exemplo.

Ao discorrerem sobre atividades dos usuários de redes sociais online, Avelino, Silveira e Souza (2018, p.118) afirmam que algoritmos "podem ser utilizados para inferir perfis psicológicos, dividir usuários em segmentos desenhando perfis de personalidade e mesmo de consumo." E ao comentarem sobre o caso do sistema de reconhecimento facial da Linha 4Amarela do metrô de São Paulo, e citarem trabalhos acadêmicos que relacionam homossexualidade, genética e padrões de reconhecimento por meio de imagens, afirmam que de acordo com tais pesquisas:

\footnotetext{
Essa tipificação algorítmica guarda um perigo imenso para os homossexuais, uma vez que governos já utilizam ferramentas faciais de coleta de informações para fazer previsões. É um perigo para todos os indivíduos que podem cair em uma categorização e serem destinados a perfis constantemente atingidos por perseguições, abusos físicos e psicológicos de todo tipo." (AVELINO; SILVEIRA; SOUZA, 2018, p.119-120)
}

No Brasil, dificuldades e até problemas mais graves causados pelo emprego inadequado, antiético ou falhas da tecnologia de reconhecimento facial também foram noticiados, como por exemplo: em 2018, nas cidades de São Carlos e Araraquara, no interior de São Paulo, crianças portadoras de necessidade especiais não conseguiram utilizar seus bilhetes eletrônicos que garantiam seu acesso gratuito ao transporte público da cidade, principalmente por não serem capazes de olhar fixamente para a câmera que geralmente é posicionada acima da catraca do ônibus (G1, 2018b) -; em junho de 2019 uma pessoa montada como drag queen teve seu bilhete eletrônico bloqueado depois de passar pelo

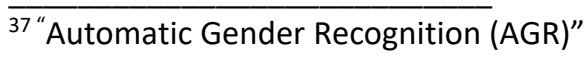


reconhecimento facial de um ônibus do sistema público de transporte da cidade de São Paulo (MOREIRA, 2019b); e em julho de 2019, duas pessoas foram detidas por engano no bairro de Copacabana (ALMEIDA, 2019; WERNECK, 2019), ao serem confundidas com criminosos pelo sistema de reconhecimento facial utilizado pela Polícia Civil e Militar do Rio de Janeiro. Além disso, a partir de um projeto do Centro de Estudos de Segurança e Cidadania (CESeC), da Universidade Candido Mendes, que gerou artigos, relatórios e infográficos, reunidos em um único volume, Nunes (2019), revela que de março a outubro de 2019, ao monitorar casos de prisões com o uso de reconhecimento facial nos seguintes estados: Bahia, Rio de Janeiro, Santa Catarina e Paraíba, a Rede de Observatórios da Segurança, da qual o autor faz parte, constatou que de um total de 151 pessoas presas, considerando apenas situações em que havia informações sobre raça e cor, - o que corresponde a 42 do total dos 151 casos -, 90,5\% das pessoas eram negras e apenas 9,5\% eram brancas.

Nunes (2019) também aponta para o recente aumento do uso de tecnologias de reconhecimento facial no Brasil, principalmente na área de segurança pública. Este fato também é confirmado pela imprensa brasileira que tem noticiado grandes investimentos públicos no setor, principalmente na região nordeste (MELLO, 2019; RODRIGUES, 2019; VALENTE, 2019). O último relatório anual, (2019), do Instituto Al Now, da Universidade de Nova York nos Estados Unidos, - um dos primeiros centros universitários de pesquisa com foco específico no significado e implicações sociais da Inteligência Artificial no mundo -, relata que cada vez mais ocorrem tentativas regulatórias, por parte de governos, baseadas em preocupações com privacidade, discriminação e vigilância, associadas à implantação de tecnologias de reconhecimento biométrico (que também englobam reconhecimento facial) em regiões como: Europa, Austrália e EUA. Porém, o mesmo relatório também afirma que os próprios governos têm adotado estas mesmas tecnologias nos mais diversos setores - como ensino, habitação, transporte, saúde, policiamento, entre outros - a uma taxa mais rápida do que a regulamentam (CRAWFORD, et al., 2019). No Brasil, Silveira (2017) afirma que o cenário não é diferente, portanto, no próximo subcapítulo, iremos apresentar outras situações de captura de dados de cidadãos com uso de TICs por parte do poder público brasileiro. Diferentes dos casos em que nos detemos mais até agora, que se relacionam também com o olhar (por envolverem dispositivos de vídeo vigilância), os próximos casos estão relacionados principalmente ao segundo componente-chave dos processos de vigilância: a informação. Porém, antes da conclusão da presente seção, ainda cabe considerarmos que a crítica que se 
faz ao abordar tais casos e situações ao longo deste trabalho, não é direcionada à tecnologia, mas ao seu emprego de forma que possa perpetuar preconceitos, reiterar estigmas, ou contribuir na manutenção de formas de exclusões sociais já presentes nos espaços de nossas cidades. Relacionada a esta perspectiva, Sibilia (2016), considera:

\begin{abstract}
Não são os aparelhos que causam mudanças nos modos de ser, como costuma se afirmar com excessiva irreflexão; mas, ao contrário, parece evidente que os artefatos técnicos são resultado de processos históricos bem complexos, que envolvem uma infinidade de fatores socioculturais, políticos e econômicos. Nesse sentido, as tecnologias são inventadas para desempenhar funções que a sociedade de algum modo solicita e para as quais carece das ferramentas adequadas. [...] A causalidade, portanto, é assim revertida: em lugar de serem compreendidos como a sua causa, os dispositivos tecnológicos são fruto de certas mudanças históricas. Uma vez criados e adotados pela população, porém, acabam reforçando essas transformações e contribuem para suscitar outros efeitos no mundo. (SIBILIA, 2016, p.25).
\end{abstract}

De acordo com a autora entendemos que não são as tecnologias responsáveis por causar estigmatização, preconceito ou exclusão social, mas sim a maneira pela qual tais tecnologias são desenvolvidas e empregadas. Dito de outra maneira, um dos caminhos para ações possíveis a favor de espaços mais inclusivos, talvez não seja destruir câmeras de vídeo vigilância (que podem sim contribuir para otimização de processos de identificação e controle de acessos), mas, empregá-las de maneira regulamentada e ética, com transparência por parte do poder público, e com participação da população civil em discussões prévias a sua implementação em espaços públicos urbanos. 


\subsection{Outras situações de captura de dados por parte do poder público brasileiro}

Ao adotar uma perspectiva semelhante à da autora Paula Sibilia (2016), citada no final do subcapítulo anterior, na qual defende que tecnologias resultam de determinadas mudanças históricas - e não as causam -, Zuboff (2018) em seu artigo seminal: Big Other: capitalismo de vigilância e perspectivas para uma civilização da informação, enfoca a tecnologia a partir de sua origem social e entende que o Big Data ${ }^{38}$ não é um processo autônomo, mas que anuncia mudanças socioeconômicas profundas. Em suas palavras, a autora defende que o Big Data é:

\footnotetext{
...o componente fundamental de uma nova lógica de acumulação, profundamente intencional e com importantes consequências, que chamo de capitalismo de vigilância. Essa nova forma de capitalismo de informação procura prever e modificar o comportamento humano como meio de produzir receitas e controle de mercado. O capitalismo de vigilância se formou gradualmente durante a última década, incorporando novas políticas e relações sociais que ainda não haviam sido bem delineadas ou teorizadas. (ZUBOFF, 2018, p.18)
}

Para a autora, nesta nova lógica econômico-social, dados produzidos cotidianamente se tornam alvos prioritários para estratégias de comercialização. (ZUBOFF, 2018). O Programa de Pós-Graduação em Ciências Humanas e Sociais da Universidade Federal do ABC realizou um mapeamento que identificou alguns dos elementos estruturantes do mercado de dados pessoais, "segmento cada vez mais importante da chamada economia informacional" (AVELINO; SILVEIRA; SOUZA, 2016, p. 218). E em uma primeira aproximação ao tema, Avelino, Silveira e Souza (2016) - pesquisadores do referido Programa -, mostraram tais elementos a partir de entrevistas realizadas com operadores do mercado de dados no Brasil, e apresentaram quatro camadas como constituintes deste mercado: coleta e armazenamento de informações; processamento e mineração de dados; análise e formação de amostras; e modulação. Posteriormente, no livro: Tudo sobre tod@s, Silveira (2017) consolida tal entendimento ao dissecar o ecossistema do mercado de dados pessoais - "conjunto de actantes, empresas, plataformas, usuários, agências, data centers, programas de rastreamento, banco de dados, entre outros dispositivos" (SILVEIRA, 2017, p. 45) -, nas quatro

\footnotetext{
${ }^{38}$ De acordo com Avelino, Silveira e Souza (2018, p. 26): “...Big Data é o nome dado pelo mercado para o armazenamento, integração, processamento e tratamento destas gigantescas bases de dados geradas cotidianamente pela sociedade global conectada".
} 
camadas citadas anteriormente, onde relaciona os agentes envolvidos com as atividades que os caracterizam em suas atuações dentro do referido mercado. Segundo o autor, sensores (dispositivos tecnológicos) espalhados pelas cidades, antenas de telefonia celular, redes sociais on-line, sites, mecanismos de pesquisa e de rastreamento de navegação, entre outros, são os principais agentes responsáveis pela primeira camada: coleta e armazenamento de dados. Ou seja: a cidade e seus elementos intrínsecos também possuem papel ativo no capitalismo de vigilância. Já a segunda camada: processamento e mineração de dados, é constituída pelos chamados brokers (agentes com qualificação técnica que empregam algoritmos e softwares de inteligência artificial). Na terceira camada: análise e formação de amostras estão os agentes que também são conhecidos como terceira parte, formado principalmente por empresas especializadas de marketing, e por fim, os agentes da quarta camada: modulação, incluem principalmente os algoritmos que controlam a visualização de conteúdos online, e que agrupam consumidores que possuem comportamentos, interesses e até ideologias parecidas. O Autor ainda destaca que "essas camadas se articulam e se misturam dependendo da organização das empresas que integram esse mercado", (SILVEIRA, 2017, p. 45), e que "existem empresas que se especializaram em uma delas e outras que atuam nas quatro camadas de atividade do mercado." (SILVEIRA, 2017, p. 46).

Segundo o autor o mercado de dados funciona da seguinte maneira: uma enorme quantidade de dados pessoais - Big data -, dos cidadãos (produzidos por eles ou a respeito deles), se encontram, em grande parte, disponíveis no espaço informacional online (o qual também se infiltra no espaço físico, constituindo espaços híbridos e ampliados na cidade contemporânea). Estes dados são capturados pelos agentes da primeira camada, que os fornecem a outros agentes (pertencentes à segunda camada) que os decodificam, os confrontam entre si e os agregam, para que gerem informações que constituam perfis ${ }^{39}$ de pessoas. Estes perfis pessoais são agrupados e transformados, pelos agentes da terceira

\footnotetext{
${ }^{39}$ De acordo com Bruno (2013, p. 159-160): os perfis assumem "um formato mais dócil, calculável, legitimando e orientando intervenções diversas. Perfis de criminosos, consumidores, profissionais, doentes físicos ou mentais, tipos psicológicos ou comportamentais apresentam-se como padrões que ao mesmo tempo ordenam e objetivam a multiplicidade humana, autorizando formas de governá-la. [...] O perfil não é nem uma medida nem um valor, mas um padrão de ocorrência de um certo fator (comportamento, interesse, patologia) num dado conjunto de variáveis. As médias e normas eram a referência comum das massas; os perfis são as microrregularidades dos nichos, tribos, grupos. [...] A taxonomia e o conhecimento não revelam aí um conjunto de características intrínsecas aos indivíduos, mas padrões de conduta e escolha na presença de fatores que constituem uma circunstância.
} 
camada, em potenciais conjuntos de consumidores para produtos e serviços diversos. O ciclo de funcionamento do mercado se completa quando estes conjuntos de consumidores recebem, demandam e adquirem os produtos finais que foram desenvolvidos e ofertados pelos agentes da quarta camada (modulação), - com fundamento principal nas análises que a segunda camada realizou, tendo como base a Big data, coletada na primeira camada dos próprios cidadãos, que se tornaram agora consumidores.

A partir da explicação de Silveira (2017), sobre o funcionamento deste segmento tão importante ao capitalismo de vigilância, torna-se evidente o motivo pelo qual o dado pessoal ${ }^{40}$ é tão valorizado nos dias de hoje: ele funciona como uma das bases de alimentação de um sistema que transforma pessoas em consumidores. E diante desta constatação, questiona-se: se sensores (dispositivos tecnológicos) que já se encontram - e também podem vir a ser - amplamente instalados em nossas cidades são capazes de capturar dados pessoais de seus cidadãos, quem pode lucrar com isso? No caso da captura de dados dos usuários da Linha 4-amarela do metrô de São Paulo, seria a concessionária ViaQuatro, e/ou as empresas que usam o espaço do metrô para campanhas publicitárias, que talvez lucrassem sobre os dados dos usuários da Linha 4-Amarela. Dito de outra maneira, este referido caso corrobora com a afirmação de Silveira (2018, p. 60), de que "os processos de modulação empregados pelo mercado também vão sendo absorvidos nas práticas de governo e nas ações das instituições políticas."

Avelino nos mostra que existem dois vieses principais de rastreamento digital: o governamental e o rastreamento privado - e informa que este último, hoje, já é o maior, e inclusive cede informações para o primeiro ${ }^{41}$. Um exemplo desta última situação de rastreamento, já mencionado neste trabalho, é o caso do Centro de Operações da Prefeitura

\footnotetext{
${ }^{40}$ De acordo com Silveira (2017, p. 43): a definição do que são dados pessoais "não é pacífica, nem meramente científica, uma vez que é disputada pelas forças do mercado de dados. Dependendo do que seja considerado dado pessoal um corretor de dados (broker) terá mais dificuldade legal para coletá-lo e vendê-lo." O autor também cita a Directiva 95/46/CE do Parlamento Europeu e do Conselho, de 24 de outubro de 1995, relativa à proteção das pessoas singulares no que diz respeito ao tratamento de dados pessoais e à livre circulação desses dados, que definiu dado pessoal como: "qualquer informação relativa a uma pessoa singular identificada ou identificável”. (SILVEIRA, 2017, p. 44). Mais informações disponíveis em: <http://eurlex.europa.eu/LexUriServ/LexUriServ.do?uri=CELEX:31995L0046:pt:HTML>. Acesso em: 27/01/2020.

${ }^{41}$ Informações cedidas por Avelino durante a palestra intitulada: "A internet e a evolução dos padrões de rastreamento e vigilância", no âmbito do Programa "Politizar as tecnologias", realizada no dia 24/04/2019, das $19 \mathrm{~h}$ às $21 \mathrm{~h}$, no Centro Universitário Maria Antônia, órgão da Pró-Reitora de Cultura e Extensão Universitária da Universidade de São Paulo.
} 
do Rio de Janeiro - COR, que opera um sistema vigilante, em determinados territórios urbanos, alimentado por dados que empresas privadas, como Twitter e Waze ${ }^{42}$, compartilham com o governo. Nesse sentido, situações ainda mais controversas têm sido divulgadas, como a parceria entre governos e conhecidas empresas especialistas no mercado da vigilância digital, como é o caso da polêmica empresa Italiana Hacking Team (VENTURA, 2915a; VIANA, 2015; WIKILEAKS, 2015). Segundo Derechos Digitales ${ }^{43}$, (2018, p.417): “é crescente o interesse pela espionagem digital por parte dos governos da América Latina." Seu relatório revela que diversos países desta região estabeleceram negociações com a referida empresa, "criadora do Remote Control System (RCS), um software espião vendido a organizações governamentais ao redor do mundo", capaz de acessar quase todo o conteúdo de um computador pessoal. (DERECHOS DIGITALES, 2018, p.417). De acordo com a organização:

\begin{abstract}
Brasil, Chile, Colômbia, Equador, Honduras, México e Panamá compraram licenças para o uso de Galileo ou DaVinci, os nomes comerciais de RCS. Argentina, Guatemala, Paraguai, Peru, Uruguai e Venezuela entraram em contato com a empresa e negociaram preços, no entanto, não há informação se as vendas foram concretizadas. [...] As negociações ocorreram em segredo, até que em 5 de julho de 2015 se expuseram publicamente 400 GB de informação da empresa [...] A partir da análise das normas vigentes em cada pais que se relacionou com a Hacking Team e pelas notícias na imprensa que surgiram na região após as revelações, o relatório conclui que o software do Hacking Team é contrário as normas legais de cada pais, bem como viola os direitos a privacidade, à liberdade de expressão e ao devido processo legal. (DERECHOS DIGITALES, 2018, p.417-418)
\end{abstract}

Derechos Digitales, (2018, p.419) ainda aponta o amplo debate, a regulamentação, as sansões penais, e o emprego da ampla transparência nas ações e políticas governamentais, como alternativas possíveis às implicações de ameaças a privacidade por parte de "um mercado global que abusa da tecnologia da vigilância nas mãos de governos ao redor do mundo".

\footnotetext{
${ }_{42}$ No website da Waze Mobilie, fica claro que a empresa tem investido na sua aproximação com governos de diversos países (FAUSTINO, 2019; TIINSIDE, 2019). Segundo as informações divulgadas, a empresa possui quase 500 parcerias ao longo do globo com instituições como: Transport for London (Órgão do governo Inglês coresponsável pelo sistema de transporte na Grande Londres, Inglaterra); Departamento de Transporte dos Estados Unidos; Centro de Mobilidade de Roma (Itália); Centro de Gerenciamento de transporte em Nova Gales do Sul (Austrália); entre outros. Mais informações disponíveis em: <https://waze.another.co/el-programa-deconnected-citizens-de-waze-celebra-su-socio-100>, e em: <https://www.waze.com/pt-BR/ccp>. Acessos em: 03 dez. 2019.

${ }^{43} \mathrm{~A}$ organização independente latino-americana Derechos Digitales, atua há 15 anos com objetivo principal de desenvolver, defender e promover direitos humanos no ambiente digital. Website official disponível em: <https://www.derechosdigitales.org/>. Acesso em 27 jan. 2020.
} 
Desde 2017, a imprensa nacional tem divulgado propostas que foram anunciadas pela prefeitura de São Paulo envolvendo projetos que poderiam ser financiados por empresas privadas em troca de dados pessoais de seus cidadãos. Entre as ofertas da contrapartida estavam: a base de dados de milhões de usuários do Bilhete Único Eletrônico de Transporte Público; os dados de navegação dos usuários do Wi-Fi Livre em troca da infraestrutura de conectividade à redes wi-fi de acesso público à internet; e dados de milhões de veículos registrados na cidade em troca do custeamento da inspeção veicular municipal (BIONI, 2017; DANTAS, Dimitrius; DANTAS, Tiago, 2017; LIMA, 2017; REIS, 2017; PREFEITURA DE SÃO PAULO, 2019).

A Estratégia Brasileira para a Transformação Digital (E-Digital) 2018, definida pelo Governo Federal do Brasil, coordenada pelo Ministério Nacional da Ciência, Tecnologia, Inovações e Comunicações, tem como um de seus eixos temáticos o acompanhamento da transformação digital da economia baseada em dados e entende o mercado de dados como elemento estratégico para o crescimento econômico, (MINISTÉRIO DA CIÊNCIA, TECNOLOGIA, INOVAÇÕES E COMUNICAÇÕES, 2018). Coletar dados pessoais dos cidadãos faz parte das atividades necessárias de um governo, uma das bases essenciais do planejamento urbano são os dados censitários de seus moradores, e o exercício da governança pública é desenvolvido fundamentalmente sobre dados pessoais da população. Os governos monitoram e identificam os indivíduos para controlar o Estado e para atender às necessidades da nação. Portanto, o problema não é o compartilhamento de dados da população com o governo, pelo contrário, isso é algo positivo e até desejado, o problema está relacionado principalmente à divulgação de tais dados para terceiros, ao cruzamento de dados entre diferentes esferas e órgãos do governo, aos fins para quais os dados estão sendo coletados e/ou cruzados, e finalmente à falta de transparência por parte do poder público ao lidar com tais questões. Desta maneira, apresentaremos a seguir algumas situações de captura de dados de cidadãos, com uso de TICs por parte do poder público brasileiro ${ }^{44}$, porém não com a intenção de elaborar uma

\footnotetext{
${ }^{44}$ O levantamento das situações de captura de dados de cidadãos, com uso de TICs por parte do poder público brasileiro, que é apresentado no presente subcapítulo, teve origem no trabalho coletivo desenvolvido pelos alunos: Brian Manieri, Lucia Helena Borges Meneghetti (também autora desta dissertação) e Renato Furquim Vry, ao longo das aulas da disciplina "DSG5013 - Arte e Design de Interface em Escala Urbana", ministradas de 13/03/2018 a 19/06/2018, pela professora doutora Giselle Beiguelman, no programa de pós-graduação Stricto Sensu em Design, na Faculdade de Arquitetura e Urbanismo da Universidade de São Paulo - FAUUSP. Na ocasião, o trabalho desenvolvido pelos referidos alunos resultou em um seminário intitulado: Dados no espaço público, que foi apresentado em 19/06/2018 durante uma das aulas da disciplina.
} 
catalogação abrangente, - até porque seria tarefa pouco viável -, mas sim com o propósito de mostrar que principalmente as finalidades, o histórico, e a preocupação em preservar a privacidade do cidadão, podem ser bastante diferentes em cada uma delas.

Uma das maneiras mais comuns pela qual compartilhamos nossos dados financeiros pessoais com o governo, de maneira compulsória, é por meio da nossa declaração anual do imposto de renda. Situações como esta já ocorriam muito antes da ascensão das TICs.

Em 1871, ainda durante o período imperial no Brasil, foi criada a Diretoria Geral de Estatística, que teve suas atividades ampliadas, mudando algumas vezes de nome até tornarse hoje o Instituto Brasileiro de Geografia e Estatística - IBGE ${ }^{45}$ entidade da administração pública federal, vinculada ao Ministério do Planejamento, Desenvolvimento e Gestão. Responsável pela coleta oficial e disseminação de informações estatísticas, econômicas, demográficas, geográficas, cartográficas, geodésicas e ambientais brasileiras, o IBGE produz informações que procuram retratar a realidade do país. Entre outras atividades, o IBGE realiza um censo nacional a cada 10 anos que coleta informações como idade, ocupação e renda familiar, nível de alfabetização e escolaridade, e condições sanitárias de todos os residentes do Brasil ${ }^{46}$. A participação da população se faz obrigatória por meio da Lei no 5.534 de 14 de novembro de 1968, e o ato de recusar ceder informações ou de ceder informações falsas para o IBGE pode ser punido com multa de até dez vezes o maior salário mínimo vigente no país, e de até o dobro desse limite quando a infração for reincidente. O texto desta Lei ainda define que:

As informações estatísticas e geocientíficas produzidas pelo IBGE são fontes fundamentais para o conhecimento da realidade do País. Através de suas pesquisas, o IBGE retrata características da sociedade brasileira, de sua população, economia e condições de vida, oferecendo um panorama completo de sua evolução ao longo do tempo. (BRASIL, 1968).

Além disso, como também é esclarecido nas respostas às dúvidas frequentes em seu site oficial:

Por lei, as informações prestadas ao IBGE são sigilosas. Nenhuma resposta será divulgada individualmente. Além disso, a lei garante também que essas informações não podem ser usadas para fins comerciais ou como prova em processo de qualquer

\footnotetext{
$\overline{45}$ Informações disponíveis em: <https://www.ibge.gov.br/institucional/o-ibge.html>. Acesso em: 22 fev. 2019.

${ }^{46}$ Informações disponíveis em: <https://www.ibge.gov.br/institucional/o-ibge.html>. Acesso em: 22 fev. 2019.
} 
natureza. As respostas individualizadas de cada entrevistado não são compartilhadas com outras instituições governamentais, empresas, entidades ou pessoas físicas. 0 acesso a esses dados é restrito aos profissionais do IBGE que atuam na pesquisa. (IBGE, online).

O censo do IBGE é um dos meios mais conhecidos pelos quais o governo brasileiro coleta dados sobre seus habitantes, mas ainda há muitas outras formas. Uma delas é através do programa da Secretaria Nacional da Fazenda chamado Nota Fiscal Paulista, cujas informações e descrição de funcionamento podem ser verificadas no website oficial do programa e no próprio portal online da Secretaria da Fazenda, conforme apresentamos brevemente a seguir.

Em operação há 12 anos no estado de São Paulo, e criado com objetivo declarado de reduzir sonegação fiscal, o Programa Nota Fiscal Paulista é obrigatório para os estabelecimentos comerciais localizados no estado e possui cerca de 19 milhões de participantes cadastrados ${ }^{47}$. O consumidor brasileiro é obrigado por lei a pagar uma porcentagem em impostos sempre que adquire um bem ou serviço, entre eles, o ICMS (imposto sobre circulação de mercadorias e prestação de serviços), porém, se o cidadão não registra a compra, não há como o governo recolher os impostos. Desta maneira, o programa incentiva os consumidores a pedirem o documento fiscal que registra a compra em troca de premiações em dinheiro que podem ser resgatadas periodicamente por meio de solicitação via site oficial do governo. Basta que o usuário faça um cadastro prévio no website do programa e informe seu CPF na hora da compra para que até $30 \%$ do ICMS recolhido pelo estabelecimento Ihe seja devolvido. Além disso, os participantes também concorrem a prêmios em dinheiro sorteados mensalmente pelo governo, que podem alcançar o valor de até dois milhões de reais nos meses de dezembro ${ }^{48}$. Diferente da proteção aplicada aos dados coletados pelo IBGE, cujo sigilo é protegido por lei, os dados dos cidadãos coletados pelo governo por meio do programa da Nota Fiscal Paulista contam com pouca ou quase nenhuma proteção, segundo Bioni e Machado (2016):

Em poucas palavras, o cidadão não tem certeza sobre por quem e como estão sendo utilizados seus dados pessoais. Não só as Secretarias da Fazenda Estaduais, mas,

\footnotetext{
47 Informações disponíveis em: <https://portal.fazenda.sp.gov.br/Videos/Paginas/Nota-Fiscal-Paulista--Doa\%C3\%A7\%C3\%A3o-Autom\%C3\%A1tica-de-Cupons.aspx>, acesso em: 01 jan. 2020.

${ }^{48}$ Informações disponíveis em: <https://www.nfpnotafiscalpaulista.com/como-funciona-nota-fiscal-paulista/>, e em: <https://portal.fazenda.sp.gov.br/servicos/nfp/Paginas/Sobre.aspx>. Acesso em: 01 jan. 2020.
} 
também, os estabelecimentos comerciais e os terceiros por eles autorizados podem ter acesso aos dados. Essa plêiade de atores pode fazer o uso que bem entender deles, pois não há nada determinando que os dados do programa devam ser única e exclusivamente processados para fins de combate à sonegação fiscal e para o cálculo de benefícios tributários por parte dos cidadãos-consumidores. (BIONI; MACHADO, 2016, p.360).

Os autores também chamam a atenção para o fato de que o programa em questão coleta muito mais dados do que precisaria para combater a sonegação fiscal e para entregar seus bônus e premiações:

[...] como o CNPJ do estabelecimento, o CPF do cidadão, o valor total pago e a data, seguem acompanhados do detalhamento das mercadorias, sua quantidade, preço, hora da transação e, até mesmo, as marcas de produtos, sendo tudo transmitido e armazenado no banco de dados da Secretaria da Fazenda. (BIONI; MACHADO, 2016, p.358).

E esclarecem que este fato vai contra um dos princípios básicos da Lei Geral de Proteção de Dados Pessoais brasileira - LGPD, chamado: princípio da necessidade, pelo qual as atividades de tratamento de dados pessoais deve se limitar "ao mínimo necessário para a realização de suas finalidades, com abrangência dos dados pertinentes, proporcionais e não excessivos em relação às finalidades do tratamento de dados." (BRASIL, 2018b).

Com a recente criação do Sistema Estadual de Coleta e Identificação Biométrica Eletrônica, - destinado à identificação pessoal de usuários de serviços públicos - o governo do estado de São Paulo aumenta a coleta de dados pessoais de seus cidadãos através do uso da tecnologia. O sistema teve sua criação determinada pelo Decreto № 63.299, de 21 de março de 2018, seu objetivo declarado é empregar padrões técnicos, tecnológicos, metodológicos e biométricos para coleta e armazenamento das dez digitais, foto do rosto e assinatura dos cidadãos, de forma a permitir a utilização, reutilização e cruzamento dos dados coletados por todos os órgãos e entidades da Administração Pública direta e indireta em todos os serviços públicos, visando economia de recursos públicos. A coleta dos dados é obrigatória a todos os cidadãos nos postos autorizados pelo governo no ato da emissão ou renovação de documentos como: cédula de identidade (RG), passaporte, carteira nacional de habilitação (CHN) e outros que gradativamente passarão a ser digitais. (SÃO PAULO, 2018a; GOVERNO DO ESTADO DE SÃO PAULO, 2018). 
Em janeiro de 2018, a deliberação № 167 do Conselho Nacional de Trânsito CONATRAN determinou a implantação da Carteira Nacional de Habilitação Eletrônica (CNH-e ou CNH Digital) pelos órgãos e entidades executivos de trânsito dos Estados e do Distrito Federal até 1ㅇ de julho de 2018, (BRASIL, 2018a). O documento, que corresponde a uma versão digital com mesma validade legal do documento em papel, é de emissão gratuita, é válida em todo o território nacional, usa os dados do Sistema Estadual de Coleta e Identificação Biométrica Eletrônica, e começou a valer em 22 de março de 2018 no estado de São Paulo. Para obter a CNH Digital, o cidadão precisa fazer seu cadastro on-line no Portal do DETRAN; validar seus dados através da certificação digital, ou pessoalmente, junto ao DETRAN de sua jurisdição; gerar o código de ativação no Portal do DETRAN on-line; instalar o aplicativo do governo, chamado CNH Digital em seu telefone celular; e gerar uma senha para habilitar sua CNH em seu aparelho móvel ${ }^{49}$. Segundo vídeo de divulgação do CONATRAN, com a certificação digital, a Carteira Nacional da Habilitação tornou-se o primeiro documento brasileiro de identificação civil com representação múltipla (física e digital), e por isso passa a ser mais segura 50 .

O aplicativo da CNH Digital não é o único aplicativo do governo brasileiro disponível para os cidadãos. O InternetLab (entidade brasileira sem fins lucrativos que produz estudos nas áreas de direito e tecnologia, sobretudo no campo da Internet), ${ }^{51}$ estudou outros aplicativos do governo disponíveis para dispositivos móveis com objetivo de conhecer: os tipos de dados que processam, as permissões que pedem e suas políticas de privacidade (quando existentes). Foram selecionados treze aplicativos do governo (oito da administração pública federal e cinco do estado de São Paulo) que foram considerados pela entidade como os que mais se inserem no cotidiano dos cidadãos brasileiros. São eles: Bolsa Família, Caixa Econômica Federal, CNH Digital, Consumidor ANATEL, CPTM Oficial, EMTU, FGTS, Metro SP, Meu Imposto de Renda, Meu INSS, Nota Fiscal Paulista, SNE DENATRAN, e SP Serviços, (ABREU; LAGO; MASSARO, 2018a, 2018b, 2018c). A pesquisa mostrou que dos aplicativos

\footnotetext{
49 Informações disponíveis em: <https://portalservicos.denatran.serpro.gov.br/\#/faq/carteiradigital>. Acesso em: 28 jan. 2020.

$50 \quad$ Vídeo disponível em: <https://portalservicos.denatran.serpro.gov.br/cnhdigital/tutoriais/html/demo_1.html>. Acesso em: 01 ago. 2018.

${ }^{51}$ Website oficial disponível em: <http://www.internetlab.org.br/pt/sobre/> Acesso em: 28 jan. 2020.
} 
estudados seis deles não possuem qualquer política de privacidade de dados acessível publicamente. E concluiu que dos aplicativos estudados poucos são os que não fazem as solicitações de permissões consideradas mais arriscadas envolvendo dados e recursos que podem até mesmo afetar a operação do aparelho ou comprometer a privacidade do usuário (como acesso a câmera, localização ou contas utilizadas no aparelho), (ABREU; LAGO; MASSARO, 2018a, 2018b, 2018c). Além disso, o Internetlab também apontou o fato de que a maioria dos aplicativos coleta muito mais dados do que precisaria para realizar as operações e funcionalidades a que se propõem, indo mais uma vez contra um dos princípios básicos da Lei Geral de Proteção de Dados Pessoais brasileira - LGPD, conforme já comentado anteriormente no presente trabalho de acordo com apontamento de Bioni e Machado (2016) em relação ao programa do Nota Fiscal Paulista.

No mesmo mês da publicação do Decreto que criou o Sistema Estadual de Coleta e Identificação Biométrica Eletrônica do Estado, também foi publicada pela Imprensa Oficial do Estado de São Paulo - IMESP, uma portaria oferecendo às pessoas jurídicas um novo serviço público pago de certificação online (IMPRENSA OFICIAL DO ESTADO S/A IMESP, 2018; SÃO PAULO, 2018b, 2018d) ${ }^{52}$. O oferecimento da certificação online de identidade por meio de dados biométricos e biográficos, visava eliminar fraudes, e permitia que pessoas jurídicas contratassem o serviço e verificassem a identidade dos consumidores, por meio do registro de seus dados biográficos (nome completo; data e cidade de nascimento; nome do pai e da mãe; número, autoridade responsável e data de expedição do RG), e por meio da coleta eletrônica de sua impressão digital, seguidos de comparação online com a base de dados biométricos da IMESP. (SÃO PAULO, 2018c). Uma Publicação no Diário Oficial do Estado de São Paulo explicava, na ocasião, como funcionava o Serviço de Certificação online:

\footnotetext{
A empresa que contrata o serviço de certificação online de identidade registra inicialmente os dados biográficos da pessoa a ser consultada e faz a coleta eletrônica de sua impressão digital. Essas informações serão comparadas às existentes na base de dados da Imprensa Oficial do Estado (Imesp), que é constituída pelos dados biográficos e as impressões digitais oficiais das pessoas físicas registradas civilmente no Estado. A empresa usuária do serviço não tem acesso a essa base de dados. Em seguida, a empresa encaminha as informações que coletou à Imesp, para consulta sobre a identidade do indivíduo. Realizada a comparação entre os dados, o resultado é enviado à empresa. Há duas possibilidades de resposta: "Confirmado", caso a
}

\footnotetext{
52 O oferecimento do novo serviço público também foi amplamente noticiado pela imprensa brasileira, ver: Affonso, (2018b), Pagnam (2018) e Tele.Síntese (2018).
} 


\begin{abstract}
impressão digital coletada corresponda à existente no banco de dados da Imesp; ou "Não é possível confirmar", quando a impressão digital coletada não corresponder à existente, ou não existir o nome ou número do RG inseridos, ou ainda se não for possível realizar a verificação em virtude da qualidade da impressão digital coletada ou da existente na base de dados. Na hipótese de o sistema não confirmar os dados, há a possibilidade de uma nova consulta, feita com a inserção de nome, número de RG e um ou mais dados biográficos adicionais do indivíduo. [...] O sistema será operacionalizado por três secretarias estaduais: Governo (por meio da Prodesp e da Imesp), Planejamento e Gestão (Departamento Estadual de Trânsito - Detran.SP) e Segurança Pública (IIRGD). (SÃO PAULO, 2018c).
\end{abstract}

Após polêmicas, e aproximadamente três meses depois de ter sido publicada em março de 2018, a portaria da IMESP, que oferecia o novo Serviço de Certificação Online, acabou sendo revogada em junho do mesmo ano, pelo novo governador do Estado de São Paulo, Márcio França, na ocasião. (FÁBIO, 2018; G1, 2018a). É importante observarmos que embora a portaria publicada pela IMESP buscasse mitigar os riscos de violabilidade de sua base de dados, - por meio da homologação do dispositivo eletrônico inteligente do servidor de dados, e do sistema computacional das pessoas jurídicas contratantes do serviço de certificação online -, ela não mencionava o que as pessoas jurídicas contratantes autorizadas poderiam fazer com os dados coletados e informações recebidas da IMESP. Também não ficava claro quem poderia contratar o serviço de certificação online - e consequentemente ter acesso aos dados -, uma vez que a portaria também não esclarecia quais eram os critérios que tais pessoas jurídicas necessitariam para ter acesso ao serviço oferecido. Além disso, uma vez que a consulta é paga, os dados dos cidadãos seriam monetizados pelo governo (sem consulta pública ou discussão prévias), assim como no caso da Linha4-Amarela do metrô de São Paulo, que abordamos no subcapítulo anterior.

Por fim, a última situação de captura de dados de cidadãos, com uso de TICs, por parte do poder público brasileiro, que abordaremos neste subcapítulo, diz respeito ao SINAN Sistema de Informação de Agravos de Notificação. Este sistema que é alimentado por notificações dos profissionais da saúde, foi implantado gradualmente a partir de 1993, e regulamentado em 1998, quando também se definiu que a alimentação regular da base de dados nacional seria obrigatória pelos municípios, estados e Distrito Federal ${ }^{53}$. A maioria das notificações é digitada nas Secretarias municipais de saúde, e na falta delas, as notificações são incluídas nas regionais de Saúde, conforme seu site oficial:

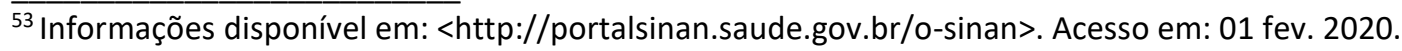


Sua utilização efetiva permite a realização do diagnóstico dinâmico da ocorrência de um evento na população, podendo fornecer subsídios para explicações causais dos agravos de notificação compulsória, além de vir a indicar riscos aos quais as pessoas estão sujeitas, contribuindo assim, para a identificação da realidade epidemiológica de determinada área geográfica. O seu uso sistemático, de forma descentralizada, contribui para a democratização da informação, permitindo que todos os profissionais de saúde tenham acesso à informação e as tornem disponíveis para a comunidade. É, portanto, um instrumento relevante para auxiliar o planejamento da saúde, definir prioridades de intervenção, além de permitir que seja avaliado o impacto das intervenções. (SINAN, 2016).

\section{O sigilo das informações pessoais integrantes da notificação compulsória por parte das} autoridades de saúde é garantido por ato administrativo (BRASIL, 2017) ${ }^{54}$, e seu Manual de Normas e Rotinas online alerta para possibilidade de maior precaução diante de situações de vulnerabilidade:

Atitudes de discriminação e frequentes violações dos direitos humanos das pessoas com doenças sujeitas ao preconceito exigem uma atenção especial quanto à confidencialidade dos dados obtidos nas investigações realizadas em todos os níveis. Em decorrência disso, o Sinan permite que se defina o nível de acesso aos diferentes módulos por meio da utilização de senhas. É de suma importância que sejam designadas as pessoas responsáveis pelo gerenciamento, acesso às bases de dados e pela interlocução entre as três esferas de governo. (MINISTÉRIO DA SAÚDE, 2007)

\section{Embora também apresentem críticas ao funcionamento do SINAN, e acreditem que o} sistema ainda precisa ser desenvolvido e melhorado, Barcellos, et al. (2018) e Bliman, et al. (2016), nos mostram que neste caso, a captura de dados pessoais sensíveis de cidadãos é perfeitamente justificada e de extrema importância:

O SINAN é gerenciado centralmente e libera relatórios anuais com dados agregados. Também possui uma interface web, onde é possível tabular casos notificados de doenças por município, mês e covariáveis. Esse sistema de notificação aberta alimentou muitas centenas de estudos epidemiológicos e contribuiu para o desenvolvimento de uma forte pesquisa epidemiológica brasileira. (BLIMAN, et al. 2016, p. 524-525, tradução nossa) ${ }^{55}$.

Várias fontes de dados se mostraram úteis para a investigação epidemiológica do Zika Vírus no Brasil. Isso inclui o sistema nacional de informação notificável (SINAN), bem como os sistemas de informação sobre mortalidade (SIM), recém-nascidos (SINASC) e alta de hospitais públicos (SIH), escalados para o nível do município (5570

\footnotetext{
54 Seção III - DAS DISPOSIÇÕES FINAIS (Origem: PRT MS/GM 204/2016, CAPÍTULO III), Art. 70.

55 "SINAN is centrally managed and releases annual reports with aggregated data. It also has a web interface where one can tabulate notified cases of diseases per municipality, month, and covariates. This open notification system has fed many hundreds of epidemiological studies and has contributed to the development of a strong Brazilian epidemiological research."
} 
municípios distribuídos em 27 estados). (BARCELLOS, et al. 2018, p.5, tradução nossa) ${ }^{56}$.

Amaral et al. (2018) também usaram outras bases de dados sobre saúde pública brasileira, e cruzaram suas informações com dados provenientes do IBGE, com objetivo de examinar a associação geoespacial entre o Zika Vírus e a microcefalia no Brasil. Segundo estes autores, isso lhes permitiu identificar graus de incidência do vírus e da doença e observar suas relações em diferentes regiões do país.

Como mostrado até aqui, e também como tem sido apontado em matérias da imprensa, e em outras pesquisas citadas neste trabalho, é possível constatar que existem situações em que o poder público brasileiro (em parceria ou não com empresas privadas) está coletando e usando dados digitais de cidadãos, sem esclarecer para a população quais dados estão sendo coletados exatamente, de que maneira estão sendo usados e quem tem acesso a eles. (BIONI; MACHADO, 2016; ABREU; LAGO; MASSARO, 2018a, 2018b, 2018c; DERECHOS DIGITALES, 2018). Além disso, depois de entendermos o complexo funcionamento do mercado de dados e seu papel dentro do capitalismo de vigilância (AVELINO; SILVEIRA; SOUZA, 2016; SILVEIRA, 2017; ZUBOFF, 2018), - que também podem ser exemplificado pelo conhecido caso entre o Facebook e a empresa Cambridge Analytica -, ficou mais difícil acreditar no discurso de qualquer instituição que colete nossos dados, seja ela pública ou privada (BAMBOZZI, 2019) ${ }^{57}$. Na ocasião, com sedes em Nova York, Washington DC e Londres, a Cambridge Analytica foi uma empresa privada que combinava mineração e análise de dados com comunicação estratégica orientada para decisões a serem tomadas principalmente em processos eleitorais. Foi criada em 2013, participou em diversas campanhas políticas, entre

\footnotetext{
56 "Several data sources have proved useful for the epidemiological investigation of ZIKV in Brazil. These include the national notifiable information system (SINAN), as well as information systems on mortality (SIM), newborns (SINASC), and public hospitals discharge (SIH), scaled to the municipality level (5570 municipalities distributed across 27 states)."

${ }^{57}$ Website oficial da empresa Cambridge Analytica disponível em: <https://cambridgeanalytica.org/>. Acesso em: 01 fev. 2020. O conhecido jornal britânico The Guardian, disponibiliza a reunião de todas as notícias que publicou sobre 0 caso no seguinte endereço eletrônico: <https://www.theguardian.com/news/series/cambridge-analytica-files>. Acesso em: 01 fev. 2020. Também foi lançado um filme documentário sobre o caso. Título original: The Great Hack, 2019, (EUA). Título em português: Privacidade Hackeada, 2019, (Brasil). Diretores: Karim Amer e Jehane Noujaim. Sob o aspecto da manipulação de dados, o Prof. Dr. Guilherme Wisnik, docente da Faculdade de Arquitetura e Urbanismo da Universidade de São Paulo - FAUUSP, também comentou o caso em sua coluna semanal, intitulada: Espaço em Obra, na Rádio USP. (WISNIK, 2019).
} 
elas na campanha presidencial de Donald Trump nos Estados Unidos em 2016, e na campanha da saída do Reino Unido da União Europeia - Brexit, no mesmo ano. Usando um pesquisador falso sob pretexto de fins acadêmicos, a empresa Cambridge Analytica coletou dados e usou informações pessoais adquiridas de usuários do Facebook, sem consentimento dos mesmos, para manipular ou induzir a opinião pública nas referidas campanhas. Investigações criminais, realizadas nestes dois países, apontaram o uso de dados pessoais de 87 milhões de pessoas desde 2014. Após o caso ganhar notoriedade na mídia, a empresa registrou seu pedido de falência em maio de 2018 em Nova York, encerrando assim suas operações nos EUA e no Reino Unido. (CONFESSORE; HAKIM, 2017; BBC, 2018; CADWALLADR; CONFESSORE; ROSENBERG, 2018; GRANVILLE, 2018; MEYER, 2018)

De acordo com Avelino, Silveira e Souza (2018, p.135) este caso e suas polêmicas "evidenciaram ainda mais o negligente esquema do mercado de dados pessoais e escancaram a fragilidade da privacidade dos indivíduos".

Embora exista um amplo consenso de que a privacidade individual dos cidadãos deva ser preservada, para que em última instância a democracia também o seja (MACHADO; ORTELLADO; RIBEIRO, 2016), - o que justifica a preocupação com a proteção dos dados pessoais dos indivíduos -, entendemos que a solução para a preservação, tanto de uma, quanto de outra, não é impedir a captura de dados por parte do governo, - afinal, sem dados a respeito dos indivíduos, seria praticamente impossível realizar o planejamento urbano ou atender às necessidades da população -, mas sim, que ele a faça de maneira transparente e ética. As práticas de coleta de dados pessoais realizadas pelo IBGE e pelo SINAN, apresentadas neste subcapítulo, por exemplo, nos parecem seguir por tal caminho, uma vez que suas políticas, entre outros tópicos, esclarecem à população que o sigilo das informações que capturam é protegido por lei ou ato administrativo; e que suas principais finalidades são extremamente necessários ao desenvolvimento do país e ao bem estar da população; como: definir estatísticas e indicadores para a melhoria da saúde pública e do planejamento socioeconômico nacional. 


\section{CAPÍTULO III - CULTURA, TERRITORIALIZAÇÃO E CONTROLE}

\subsection{Cultura e estéticas da vigilância}

Há um consenso nesse campo de pesquisa, de que os atentados de 11 de setembro de 2001 nos Estados Unidos, tiveram papel importante na legitimação e no aumento de práticas securitárias, que implicam dispositivos tecnológicos ou sistemas vigilantes instalados em espaços públicos, em diversas regiões do globo, principalmente em países como Estados Unidos e Europa. (LEMOS, 2010; BRUNO, 2013; BEIGUELMAN, 2016a; FIRMINO, 2018; LYON, 2018). A bibliografia sobre o tema também mostra que após a divulgação de documentos sigilosos da Agência de Segurança Nacional Estadunidense - NSA, por parte de Edward Snowden em junho de 2013, as alianças entre governos e empresas privadas, em atividades transnacionais de vigilância online, tornaram-se ainda mais evidentes. (BEIGUELMAN, 2016a; RENNÓ, 2016; EVANGELISTA et al., 2018; LYON, 2018; ZUBOFF, 2018).

\footnotetext{
É quase uma obviedade dizer que a vigilância é uma grande indústria. Corporações globais estão envolvidas, muitas vezes intimamente ligadas a governos. As divulgações de Snowden tornaram isso largamente claro, se antes restava alguma dúvida. Desde o princípio, em junho de 2013, os documentos de Snowden mostraram que a NSA tem acesso aos metadados de companhia telefônica (Verizon) e que também garimpa as bases de dados de clientes de empresas de internet como Apple, Google, Microsoft, Amazon e Facebook (por vezes mencionadas como as "Cinco Grandes"). Por um lado, portanto, essas empresas se envolvem com vigilância de seus clientes em larga escala; por outro, elas partilham esses dados com agências governamentais. (LYON, 2018, p. 155).
}

Porém, como também vimos ao longo do presente trabalho, e de acordo com Koskella (2010, p. 175), com o advento e popularização das TICs, e especialmente das redes sociais online, "a vigilância mudou fundamentalmente de um 'aparato político centralizado' para uma prática a qual qualquer um pode contribuir", gerando o paradoxal estado de shareveillance (ou vigilância-compartilhada, em tradução livre). Bichall (2017) emprega o termo shareveillant - criado por ela ao fundir os termos share (compartilhamento) e veillance (vigilância) -, com objetivo de problematizar o caráter geralmente positivo, benéfico e ético que a palavra compartilhamento carrega. A autora aborda a questão do compartilhamento digital, também com ênfase na questão da participação do usuário na vigilância em rede, e afirma que os discursos sociais dominantes costumam enfatizar vantagens e associar 
qualidades - como ética e aceitação social -, aos indivíduos que compartilham (BIRCHALL, 2017).

Ao levar em conta a contribuição e papel ativo dos indivíduos contemporâneos na vigilância, Lyon (2018) emprega o termo cultura da vigilância para melhor caracterizar algo que está profundamente inserido em nossas práticas cotidianas e em nossos modos de vida. Para o autor, os termos mais antigos como Estado de vigilância e sociedade da vigilância já não dão conta de caracterizar tal fenômeno, pois se referem a "algo externo que se impõe em nossa vida" (LYON, 2018, p. 153). Tais termos, hoje, "devem ser complementados por um conceito que se concentre mais nos papéis ativos e desempenhados pelos sujeitos da vigilância, primeiramente porque tais papéis fazem diferença nos resultados da vigilância." (LYON, 2018, p.152). Nesse sentido, Bruno (2013) também aponta o caráter multifacetado da vigilância distribuída, que pode englobar não só a vigilância exercida por governos e grandes instituições privadas, - por meio de dispositivos ou sistemas construídos para vigiar, que podem agenciar grande número de indivíduos -, com foco em grupos específicos, mas também a vigilância exercida por um cidadão, com foco na vida comum de outra pessoa. Esta vigilância, cujo foco da visibilidade está no indivíduo e na sua vida cotidiana, é aquela exercida entre familiares e conhecidos, constante muitas vezes em narrativas pessoais, especialmente em redes sociais online (BRUNO, 2013). A autora também nos mostra que diversas atividades de vigilância na internet importam procedimentos de instâncias policiais, administrativas, ou científicas para campos familiares e afetivos:

\begin{abstract}
A chamada no site do Spokeo, por exemplo, conclama: "Descubra fotos pessoais, vídeos e segredos (...) Dê uma olhada nos seus contatos de e-mail para descobrir fatos surpreendentes sobre seus amigos." Paralelamente e misturando-se a este apelo investigativo e voyeurístico, os serviços oferecem uma otimização das relações sociais, possibilitando descobrir quem é ou não confiável, conforme os interesses em jogo. Encontros amorosos são precedidos de procedimentos de checagem de informações (DateSmart, Instant CheckMate), assim como inúmeros softwares ofertam serviços de monitoramento das atividades on-line de cônjuges e familiares (Catchacheat, Sentry Parental Control) vendendo vigilância, desconfiança, proteção e afeto num mesmo pacote. (BRUNO, 2013, p.132).
\end{abstract}

Nesta mesma perspectiva, ao abordarem estéticas da vigilância presentes em mídias audiovisuais contemporâneas, Bruno e Lins (2010) e Beiguelman (2016a; 2016b) indicam para uma popularização e diversidade de dispositivos tecnológicos, entre outros agentes, responsáveis por inserir a vigilância em diferentes esferas sociais:

“A vigilância hoje está ao alcance de todos com a proliferação de engenhos de todo tipo, capazes de produzir imagens nos mais variados registros. Toda câmera é 
potencialmente uma câmera de vigilância: vídeo, cinema, celular, máquina fotográfica, scanner, webcam etc., e delas podem ser operadores ou protagonistas qualquer um, conhecido ou não. Vigilância e espetáculo se entrecruzam e, tanto em um quanto em outro, podemos reconhecer não apenas um método de controle, mas também um repertório cultural multifacetado. Uma câmera pode muito bem ser um índice de segurança e/ou ameaça, de censura e/ou exibicionismo, de controle e/ou de prazer. [...] Às "visões sem olhar" automatizadas dos circuitos fechados de controle e punição, somam-se as imagens capturadas por uma multidão de "autores", homens e mulheres com câmeras na mão prontos a filmar tudo e qualquer coisa que possa "interessar"; visões produzidas por uma legião de olhares e subjetividades desejosos de imprimir uma marca naquilo que filmam." (BRUNO; LINS, 2010, p. 216)

Embora tenhamos deixado claro, no subcapítulo 1.3 do presente trabalho, sobre a diferença existente entre visibilidade e vigilância, Beiguelman (2016a) e Han (2018), citam o Gloogle Glass (dispositivo tecnológico vestível, da Empresa Google, em formato de óculos, que carrega a maioria das funções de um smartphone, e também é equipado com recurso de Realidade Aumentada ${ }^{58}$ ) e nos mostram que a tecnologia atual pode nos levar a situações onde o ver se confunde com o vigiar, exemplificando desta maneira, sua capacidade possível de transformar "qualquer pessoa em um sistema móvel de vigilância" (FIRMINO, 2018, p. 74), ilustrando o cenário abordado por Bruno e Lins (2010) na citação feita anteriormente:

\begin{abstract}
Justamente esses óculos de dados tornam, porém, possível que sejamos permanentemente fotografados e filmados por estranhos. Com os óculos de dados, cada um praticamente carrega consigo uma câmera de vigilância. Sim, os óculos de dados transformam o olho humano ele mesmo em uma câmera de vigilância. O ver coincide inteiramente com a vigilância. Todos vigiam todos. Todos são o Big Brother e o presidiário simultaneamente. (HAN, 2018, p. 127)
\end{abstract}

Ao mencionar os ataques na Maratona de Boston em 2013, onde "grande parte das informações utilizadas pela polícia para capturar os irmãos Tsarnaev foi baseada em vídeos, imagens e comentários produzidos por cidadãos comuns", (FIRMINO, 2018, p.175), o autor também afirma que a maneira mais recente usada para securitização de espaços é justamente essa capacidade de controle remoto e monitoramento - seja centralizada e integrada como a vigilância praticada pelo COR, já citada no presente trabalho; ou dispersa e fragmentada como a praticada por cidadãos comuns com o uso das TICs (FIRMINO, 2018). Outra situação em que

\footnotetext{
${ }^{58}$ De acordo com Beiguelman, (2016, p.19), a Realidade Aumentada (RA) também utiliza tecnologias de geolocalização, e possibilita "visualizar objetos informacionais que acrescentam dados a um determinado local, por meio de animações em computação gráfica, superpondo-se, em tempo real, às imagens enquadradas pela câmera".
} 
as referidas tecnologias também contribuíram em investigações criminais, aconteceu no Brasil, onde buscas na internet, análises de imagens de câmeras de vigilância instaladas na cidade, e triangulação de sinais de celulares, permitiram que a polícia do Rio de Janeiro identificasse, e prendesse, indivíduos com suspeitas de envolvimento no conhecido caso de assassinato da então vereadora carioca Marielle Franco, ocorrido em março de 2018. (FÁVERO, 2019; LAVADO, 2019; PADRÃO, 2019)

Situações como estas também evidenciam o caráter ambivalente da presença das TICs que contribuem para a vigilância no espaço público, que podem contribuir para gerar estigmatização, preconceito ou exclusão social - como em casos apontados no subcapítulo 2.1 da presente dissertação, mas também podem contribuir para o cumprimento da justiça como nos casos mencionados das investigações realizadas pela polícia de Boston e do Rio de Janeiro.

Firmino (2018) compreende principalmente as relações entre TICs e espaço, trata de vigilância, tecnologia e sociedade, especialmente no campo da arquitetura, enfocando o fenômeno da formação e sobreposição de camadas territoriais urbanas como meio de apropriação de espaços (físicos e informacionais) nas cidades, e afirma que na América Latina:

Há uma naturalização e banalização de artifícios capazes de promover uma manifestação e uma declaração físico-material-arquitetônica, em que cercas elétricas, câmeras, muros reforçados, cercas militares, guaritas e outros tipos de elementos de securitização já se incorporaram à linguagem da arquitetura e do design, com ênfase em uma visível agressividade. Na verdade, percebe-se que no mercado imobiliário há uma valorização excessiva desse tipo de 'ambiente protegido'. (FIRMINO, 2018, p. 82)

A novidade, segundo o autor, é que hoje residentes ou grupos de residentes de áreas da cidade que não são muradas, ou que não pertencem a um condomínio fechado, têm usado tais elementos de securitização também fora de seus lotes individuais e voltados para vigiar o espaço público no entorno de suas residências. (FIRMINO, 2018). Desta maneira, em alguns casos "novas formas imateriais, digitais e codificadas de vigilância e securitização [...] são usadas não somente para reforçar os limites já estabelecidos mas também para estender as fronteiras territoriais e de exercício de poder." (FIRMINO, 2018, p.86-87).

Bruno, Firmino e Kanashiro (2010) também apontam para os dispositivos de vigilância presentes em diversas cidades, com ênfase em países americanos como Brasil, México e Estados Unidos. Botello (2007) acrescenta que o fenômeno tem ocorrido principalmente nos 
últimos 25 anos, e em escala global. Evangelista et al., (2018) afirma que eventos internacionais de grande porte, como a Copa do Mundo 2014 e os Jogos Olímpicos de 2016, realizados no país, contribuíram para intensificar o monitoramento, por parte do poder público brasileiro por meio de câmeras, pautado no discurso de prevenção à ataques terroristas, porém, a mesma tecnologia "tem sido usada também na repressão de manifestações públicas", (EVANGELISTA et al., 2018, p.397). Ainda se referindo ao Brasil, também segundo estes autores: "o barateamento da tecnologia e a consequente popularização do uso desses equipamentos tornam quase impossível circular por espaços urbanos sem ser alvo das câmeras em algum momento." (EVANGELISTA et al., 2018, p.397). Desta maneira, identificamos a necessidade da adoção de uma noção genérica de cidade para efeito da discussão específica na presente dissertação. É importante esclarecer que não se trata de adotar um olhar homogeneizante do espaço, ou um ponto de vista a partir de uma determinada realidade socioeconômica, pois como esclarecem Bruno (2013), Beiguelman (2016b; 2019) e Lyon (2018), os cenários são multifacetados, complexos e podem sofrer mutações ao longo do tempo. Além disso, se compreende que nem todas as pessoas ou regiões do globo possuem acesso à tecnologia e, portanto, não se enquadrariam no fenômeno mencionado. Porém, argumenta-se que mesmo indivíduos que não tem acesso à tecnologia, acabam na maioria das vezes sendo afetados justamente pela falta de acesso a ela, como nos mostra Crary (2016) quando afirma que as inovações tecnológicas operam numa lógica de obsolescência programada, que estimula a demanda por substituição ou aprimoramento de produtos diversos, desempenhando um papel decisivo na reinvenção do sujeito e na intensificação do controle. O autor explica que esses produtos (artefatos ou serviços) se tornam o padrão ontológico dominante - ou excludentes - em nossa realidade social à medida que inúmeros seres humanos vivem em um nível de subsistência que não lhes permite acessar tais produtos, nem serem integrados às novas exigências dos mercados, fazendo com que se tornem irrelevantes ou dispensáveis. "Como em outras esferas, o envolvimento social com novas tecnologias não pode ser resumido em capacidades tecnológicas ou disponibilidade. Esses são fenômenos sociotécnicos" (LYON, 2018, p.160).

Ao pesquisarem as diferentes formas de identificação civil no Brasil, e tratarem sobre um caso de fraude de identidade de um cidadão brasileiro, Firmino e Wood (2010) afirmam que: 
Há dois tipos opostos de medo responsáveis pelas reações de cidadãos a esquemas de identificação do Estado. [...] O primeiro, mais conhecido em Estados como os EUA e o Reino Unido, é o pesadelo da ordem, onde a privacidade vai sendo destruída à medida em que o Estado se torna cada vez mais intrusivo e controlador. Contudo, o outro é o medo da exclusão, onde a principal preocupação dos cidadãos é tornaremse desconhecidos e, portanto, potencialmente desaparecerem como vítimas de forças arbitrárias. Argumentamos que o caso brasileiro, esse último receio é quase universal, e que o medo do anonimato e de tornar-se "perdido" é consideravelmente maior que qualquer inquietação sobre a vigilância e o controle." (FIRMINO; WOOD, 2010, P.250)

Os resultados da pesquisa de Firmino e Wood (2010) também nos mostram que "a cultura da vigilância tem muitas facetas e varia de acordo com a região", (LYON, 2018, p.158), mas, apesar disso, e de estar em transformação contínua, Lyon (2018, p. 159), esclarece que esta mesma cultura também apresenta particularidades comuns. Suas características gerais são elencadas, tanto pelo autor, quanto por Bruno (2013), sendo que as preponderantes são: a) participação crescente dos sujeitos na vigilância, principalmente por meio de mídias sociais online, e pelo imperativo social contemporâneo de compartilhamento de dados pessoais (que também pode ser encarado como um aspecto da auto exposição por parte de indivíduos que desejam a visibilidade); b) aceitação da vigilância sem questionamento por parte das pessoas, justificada na maioria das vezes pelo medo, familiaridade, entretenimento, ou até mesmo dificuldade para identifica-la ou recusá-la; c) legitimação da vigilância divididos em três campos principais: por aspectos de visibilidade da vida cotidiana dos indivíduos, em suas relações sociais; pela lógica do risco, onde o medo legitima e gera discursos de securitização; e pela lógica da eficácia (que requer o emprego da tecnologia que potencializa a vigilância). Por sua vez, tanto os discursos de securitização, quanto a lógica da eficácia, também têm sido usados para justificar a implementação de sistemas, e aparatos tecnológicos - com finalidade de vigilância e controle, entre outros fins -, principalmente na construção de novas cidades chamadas de smarts, ou inteligentes, e na transformação de cidades já existentes em smart cities, conforme mostraremos a seguir. 


\title{
3.2. Cidades inteligentes, exclusão, e novas geografias
}

Segundo Figueiredo (2016), não há uma definição precisa ou consensual para o conceito de cidade inteligente, porém, Goodspeed (2014) reuniu definições publicadas em fontes diversas, tanto por estudiosos, quanto pelos agentes e empresas que promovem as chamadas cidades inteligentes, e resumiu sua conceituação como aquela que:

\begin{abstract}
persegue os objetivos de serviços e sistemas de cidades eficientes, usando monitoramento e controle em tempo real. A cidade se torna um sistema a ser otimizado ou executado com eficiência. Para alcançar tais objetivos, a cidade é instrumentalizada por meio do uso de sensores para coleta de dados, e de agentes ou dispositivos de controle, que podem incluir os próprios moradores da cidade. (GOODSPEED, 2014, p.83, tradução nossa) ${ }^{59}$.
\end{abstract}

A literatura sobre o tema geralmente distingue dois grandes grupos ou gerações de smart cities: as cidades canônicas, 100\% inteligentes, ou que já nasceram inteligentes e as cidades que foram ou estão sendo smartizadas (ROZESTRATEN, 2016; RENNÓ, 2016; GREENFIELD 2017; FIGUEIREDO, 2018). As primeiras foram protótipos idealizados por empresas de tecnologias e incorporadoras imobiliárias em torno da primeira década dos anos 2000, cujos projetos desenvolvidos por conhecidos escritórios de arquitetura partiram do zero, em locais que não abrigava qualquer tipo de ocupação permanente (FIGUEIREDO, 2018). São exemplos, as cidades de Masdar (Emirados Árabes Unidos) e Songdo (Coréia do Sul). Ao analisar a situação de tais cidades, hoje, aproximadamente dez anos após terem sido idealizadas, Figueiredo (2018) nos mostra que principalmente suas promessas de sustentabilidade se mostraram inalcançáveis, e que seus espaços permanecem quase vazios. O autor, assim como Rozestraten (2016), também aponta para a falta de elementos que constituem uma cidade: "não há diversidade social, nem produção de bens de consumo, nem espaços públicos, muito menos sedes dos poderes judiciários ou legislativos em tais empreendimentos. Não há espaços de representação política democrática" (ROZESTRATEN, 2016, p.23).

\footnotetext{
${ }^{59}$ pursues the goals of effective services and eficiente city systems through real-time monitoring and control. The city is a system to be optimised or run efficiently. To do this, the city is instrumented, which means using both sensors for data collection and actuators or control devices that might include city residents themselves.
} 
Já a segunda geração de cidades, que se tornaram, ou estão se tornando, inteligentes, abrange cidades já consolidadas que tem recebido a implantação de uma variedade de programas, sistemas e dispositivos tecnológicos principalmente nos domínios da gestão e do planejamento urbano (GOODSPEED, 2014; RENNÓ, 2016; GREENFIELD 2017; FIGUEIREDO, 2018), geralmente agrupados em duas linhas de projeto que priorizam "infraestrutura de sensoriamento e controle, ou promoção de capital humano, e não compondo com ambas de maneira complementar" (FIGUEIREDO, 2018, p.46). O autor usa a cidade do Rio de Janeiro para exemplificar sua fala:

\footnotetext{
O Centro de Operações da Prefeitura, por exemplo, trabalha com sistemas de coleta, transmissão e processamento de dados para conferir visibilidade operacional e capacidade de ação plenas aos gestores da cidade. O LabRio de participação cidadã, por outro lado, acredita na descentralização do planejamento estratégico da cidade por meio da promoção de instâncias on-life de capacitação e participação cidadãs, e disponibilização de meios e ferramentas on-line para proposição e encaminhamento de políticas públicas pela população. As iniciativas não são complementares devido à ausência de uma diretriz convergente por parte da Prefeitura, de forma que não fica claro se o Rio de Janeiro busca ser a cidade onisciente que permite ação instantânea por parte de um grupo gestor ou a cidade legível, inclusiva e participativa em sua condução." (FIGUEIREDO, 2016, p.5)
}

A sobreposição hierárquica de um campo do conhecimento - principalmente o tecnológico - em detrimento de outras áreas, no estudo, discussão e gestão do espaço urbano também é uma das principais críticas na literatura sobre as smart cities (GOODSPEED, 2014; RENNÓ, 2016; ROZESTRATEN, 2016; GREENFIELD 2017; FIGUEIREDO, 2018). Ainda assim, é como integrante desta segunda geração, que a mídia internacional tem classificado a cidade brasileira do Rio de Janeiro, - entre cinquenta outras, como Melbourne (Austrália), Nova York (EUA), e Oslo (Noruega) - como sendo uma das mais inteligentes do mundo, (ROTHMAN, 2014; O GLOBO, 2015; FORBES, 2018; PEZZOTI, 2019).

De acordo com Rennó (2016), o resumo conceitual de Goodspeed (2014), que citamos no início deste subcapítulo, revela a visão positivista atrelada a ideia da Smart City, que enxerga a tecnologia como grande solução para os problemas da cidade contemporânea entendida como falha. Para a autora, neste modelo, "conceitos como inovação, eficiência e desenvolvimento acabam sendo transportados da esfera privada para a pública, como uma ferramenta discursiva que serve de base argumentativa para o controle e privatização dos espaços públicos" (RENNÓ, 2016, p.14). E diante da crescente implementação de dispositivos tecnológicos de controle automático em espaços urbanos, Rennó $(2016$, p. 15) questiona "se 
estas novas tecnologias servem como alternativa às tensões e conflitos na cidade ou apenas reforçam sistemas de exclusão já presentes". Ao analisar o modelo urbanístico da cidade inteligente no contexto brasileiro, Figueiredo (2016) defende que sua aplicação pode reforçar desigualdades em cidades como as brasileiras cujas instituições formais e informais já produzem opressão e diversos tipos de segregações socioeconômicas. Nesse sentido, Hatuka e Toch (2017), afirmam que:

\begin{abstract}
As práticas de vigilância são utilizadas em muitas cidades que têm instalado meios tecnológicos para monitorar e controlar os espaços públicos com o objetivo de reduzir o medo e a ansiedade entre os habitantes. Ideias e projetos como "Cidade Segura", "Cidade sem Violência" e "Cidade Inteligente" [...], propõem "proteger" as pessoas nos espaços urbanos, monitorando e observando indivíduos e / ou rastreando locais e atividades das pessoas para "otimizar serviços". De maneira importante, tecnologia e design servem para aumentar a vigilância do espaço público. [...] Essas ideias e projetos têm o custo de excluir grupos definidos como perigosos ou simplesmente não-consumidores, de modo que o acesso e a segurança podem entrar em conflito. (HATUKA; TOCH, 2017, p.2, tradução nossa) ${ }^{60}$.
\end{abstract}

Nesta citação, os autores não se referiram especificamente a nenhuma das situações que discutimos anteriormente no presente trabalho, como as duas iniciativas de implantação de câmeras de reconhecimento facial do metrô de São Paulo, ou o Programa de Monitoramento Virtual da Fronteira do Texas - cujos objetivos declarados foram: otimização de serviços, incremento de vendas, e garantia de segurança, nos dois primeiros casos; e redução do crime fronteiriço, no terceiro -, mas, podem nos fazer refletir sobre elas, e particularmente, sobre as implicações que citamos relacionadas a elas, como: exclusão social e possibilidade de discriminação de gênero. Tais reflexões fazem ainda mais sentido, se ponderarmos históricos de pesquisas como o estudo sobre a implantação de câmeras de monitoramento para segurança em São Paulo, desenvolvida por Kanashiro (2006), a partir da análise de caso realizada no Parque da Luz, na região central da cidade, que levou a pesquisadora às seguintes considerações:

\footnotetext{
${ }^{60}$ Surveillance practices are used in many cities that have installed technological means to monitor and control public spaces with the aim of reducing fear and anxiety among inhabitants. Ideas and projects such as 'Safe City', 'City without Violence' and 'Smart City' [...], propose to 'protect' people in urban spaces by monitoring and observing individuals and/or tracking people's locations and activities to 'optimise services'. Importantly, technology and design both serve the increased surveillance of public space. [...] These ideas and projects 'come at the cost of excluding groups defined as dangerous or simply non-consumers, so access and safety can clash'.
} 
No contexto brasileiro, a utilização da tecnologia confere ainda um caráter de aparente modernização da segurança e se conjuga, nos espaços públicos do centro de São Paulo, com um projeto "moderno" de gerenciamento das cidades, que congrega noções como a de ascensão à modernidade, e que acarreta em segregação espacial, discriminação social e restrição da acessibilidade aos lugares. Os "modernos" dispositivos de segurança, como as câmeras de monitoramento, representam em nível local, não apenas uma solução para a diminuição do medo e da insegurança, mas uma espécie de sensação de ascensão a um outro patamar de desenvolvimento, que a tecnologia parece representar. (KANASHIRO, 2006, p. 6566).

É inaceitável que em São Paulo, ou em qualquer outra cidade, o uso do espaço público pelos cidadãos sofra restrições a sua acessibilidade, assim como a tecnologia não deveria ser empregada para reprimir manifestações públicas, especialmente como tem acontecido na cidade que é apontada pela mídia como uma das mais inteligentes do mundo: Rio de Janeiro (KAYYALI, 2016; EVANGELISTA et al., 2018). Porém, a questão do controle é justamente mais um dos problemas apontados na literatura sobre o tema das Smart Cities, uma vez que a captura de dados e as informações a respeito dos cidadãos, e sobre tudo o que acontece na cidade, seriam a chave para alcançar a almejada eficiência, que levaria a perfeição (RENNÓ, 2016; GREENFIELD, 2017). Tais informações "são administradas e analisadas pelas grandes empresas de tecnologia que dominam o setor como Cisco, IBM e Telefônica, em colaboração com o poder público." (RENNÓ, 2006, p.14). E ao considerar a quantidade de situações, e o grau de envolvimento de tais empresas em supervisão e controle de informações, tanto da população quanto de processos municipais na smart city, Greenfield (2017) considera insuficiente o grau de abertura e de acesso que estas empresas impõem aos dados que captura. Ainda segundo o autor, as informações e o gerenciamento da vida pública citadina não deveriam ser de propriedade particular e muito menos monetizados. "À medida que a cognição e o movimento são traduzidos e capitalizados dos usuários para a nuvem, a vida cotidiana e o pensamento na cidade inteligente se transformam em espécies de trabalhadores para a informação" (BRATTON, 2015, P.159, tradução nossa) ${ }^{61}$, para o autor, a Smart city é parte da estrutura, ou do cenário ideal, para que o cidadão e seus atos passem a servir às empresas responsáveis pela captura e monetização de seus dados - estas últimas, descritas pelo autor como plataformas em nuvem. Rennó $(2006$, p.5), também aponta preocupações

\footnotetext{
$\overline{61}$ as cognition and movement are translated and capitalized from User to Cloud, everyday living and thinking in the smart city become a form of information labor.
} 
com o tratamento dos dados gerados e capturados em um modelo de smart city, e relembra o episódio das divulgações de Snowden, mencionado no subcapítulo anterior, a respeito da espionagem de dados praticadas pela NSA, que "permitiram ao governo determinar redes sociais, condições de saúde, crenças religiosas e muito mais. Os dados gerados pelas várias tecnologias das cidades inteligentes serão ainda mais abrangentes, massivos e reveladores".

Conforme mostrado ao longo do presente trabalho, as parcerias entre governos e empresas privadas para implantação de TICs, que operam geralmente por captura de dados, no espaço híbrido e ampliado da cidade contemporânea, têm sido cada vez mais frequentes, inclusive no contexto brasileiro. Neste sentido, Figueiredo $(2018$, p.53), aponta para o que seria uma terceira geração de smart cities, - concedendo-lhes o título autoexplicativo de minas de dados -, onde o modelo consolidado de cidade inteligente adota uma narrativa mais humanizada e "encontra espaço também na agenda de governos estaduais e federais [...] os portfólios das empresas e as experiências realizadas até então são utilizados como base para fundamentar políticas públicas". A esse respeito, segundo Bratton (2015), a novidade é que para além do estabelecimento de parcerias entre governos e empresas, suas atribuições também têm se embaralhado:

\footnotetext{
Ao mesmo tempo em que as plataformas em nuvem também assumem atribuições tradicionais de governo, como cartografia pública, identidade legal, moeda, obediência a protocolo e até patriotismo, os próprios estados também evoluem para se tornarem entidades baseadas em nuvem. (BRATTON, 2015, p. 109, tradução nossa) $)^{62}$.
}

Parte do cenário a que Bratton (2015) se refere também pode ser ilustrado a partir de um exemplo recente ocorrido no Brasil, conforme mostraremos a seguir. Em dezembro de 2019, o Governo do estado de São Paulo anunciou um projeto de mapeamento digital de propriedades e estradas rurais a ser implantado pela Google, ao qual - ao menos no discurso -, se atribuiu a função estatal do endereçamento, (GOVERNO DO ESTADO DE SÃO PAULO, 2019; SOPRANA, 2019). A iniciativa foi comentada por (FOLETTO et al., 2019), que entendem que o projeto se relaciona mais a "uma estratégia de expansão do alcance territorial da

\footnotetext{
${ }^{62}$ At the same time that Cloud platforms also take on traditional governing assignments such as public cartography, legal identity, currency, protocol allegiance, even patriotism, states themselves also evolve toward becoming Cloud -based entities.
} 
Google", do que ao atendimento a uma real necessidade de endereçamento de áreas rurais e urbanas localizadas no estado. "O endereçamento é uma função importante do Estado na direção de conferir status oficial a moradias e estabelecimentos e, assim, ampliar o acesso a direitos e serviços diversos" (FOLETTO et al., 2019). De acordo com estes autores, o que o Google se propõe a fazer não é endereçamento e sim a geocodificação - conversão do endereço existente, ou especificado, em coordenadas de localização geográficas, que podem ser usadas em aplicações digitais -, e a geolocalização - identificação de um endereço existente, ou especificado, a partir de coordenadas:

\begin{abstract}
Para cada endereço transformado em coordenada, a Google cobra 0,005 dólares caso o usuário ultrapasse uma cota inicial de 200 dólares, disponibilizada gratuitamente por usuário todo mês. A Google também cobra de serviços de geolocalização (o serviço contrário, ou seja: transformar coordenada em endereço) e de desenho de rotas solicitados ao seu servidor. [...] O Estado poderia proceder como sempre fez, dando apenas um nome à rua e um número aos imóveis, mas opta por incluir o código da empresa - liberando-a, assim, de ter que atualizar os endereços por extenso em seus serviços para manter sua precisão. Não há ganho de eficiência, pois para obter o plus code o Estado precisa especificar as coordenadas dos imóveis, e para isso precisa de informação com detalhe suficiente para executar os procedimentos convencionais. [...] O trabalho é todo do Estado, que passa a incluir o código nos cadastros oficiais de propriedade. (FOLETTO et al., 2019)
\end{abstract}

Outro exemplo do embaralhamento entre os papéis do Estados e de Empresas na gestão de cidades ou nações, que miram e disputam o território informacional planetário e definem novas geografias políticas, pode ser observado no notório conflito ocorrido entre a Google e a China, intitulada por Bratton (2015, p.112, tradução de Beiguelman, 2018) ${ }^{63}$ como "a primeira guerra Sino-Googlesa de 2009". A origem do conflito se deu porque o governo Chinês desejaria restringir a atuação da Google em seu país por motivos de censura política. A princípio a empresa havia se recusado a instalar filtros de bloqueio em seus sistemas de buscas online, mas posteriormente acabou cedendo às exigências do governo - muito provavelmente pelo motivo maior de não querer correr o risco de perder um mercado de mais de um bilhão de habitantes (AKA, 2011; METAHEAVEN, 2012; BRATTON, 2015; BEIGUELMAN, 2019). Porém, os filtros instalados pela Google se mostraram pouco eficientes aos olhos da

\footnotetext{
${ }^{63}$ O nome original empregado por Bratton (2015, p.112) é First Sino-Google War of 2009. O episódio também foi apresentado, e acrescido de informações, pela professora doutora Giselle Beiguelman ao longo das aulas da disciplina "DSG5013 - Arte e Design de Interface em Escala Urbana”, ministradas de 13/03/2018 a 19/06/2018, no programa de pós-graduação Stricto Sensu em Design, na Faculdade de Arquitetura e Urbanismo da Universidade de São Paulo - FAUUSP.
} 
China, que por consequência acabou proibindo por completo a atuação da empresa no país. Na ocasião, o presidente da Universidade de Correios e Telecomunicações de Pequim, Fang Binxing, um dos envolvidos no desenvolvimento de ferramentas técnicas para bloqueios online no país, fez duas analogias da situação, - que implicava em direitos de jurisdição -, uma ao tráfego das companhias aéreas através de fronteiras; e outra à água (que não pertence a ninguém), e ao leito de rios (que pertencem a limites nacionais), (AKA, 2011). Para o acadêmico, a Google detinha a água (dados), mas, a China detinha o leito dos rios. Ao bloquear o leito dos rios, a água da Google não seria mais capaz de circular nos rios chineses. Aka (2011, tradução nossa) ${ }^{64}$ transcreve parte do discurso de Fang Bixing, onde o acadêmico afirma que "a água não tem nacionalidade, mas os leitos dos rios são territórios soberanos, [logo] não podemos permitir que a água poluída de outros estados-nações entre em nosso país." O conflito durou alguns anos e posteriormente a Google acabou voltando a atuar na China, porém com sistemas de bloqueios e filtros que passaram a satisfazer as exigências do governo em questão. (AKA, 2011; METAHEAVEN 2012; BRATTON, 2015; BEIGUELMAN, 2019). De acordo com Bratton (2015):

\begin{abstract}
Houve, e é, um conflito não apenas sobre o direito de controlar os resultados dos mecanismos de busca, mas também sobre a predominância de dois modos diferentes de soberania. $O$ conflito coloca um estado que dominaria e determinaria a soberania da rede dos fluxos de informação e energia, versus uma plataforma que, reunindo usuários em outra rede real e comunidade imaginada, excedesse, por ação, se não por letra, a última instancia de soberania do estado e determinaria uma política alternativa em sua própria imagem. (BRATTON, 2015, P.159, tradução nossa) ${ }^{65}$
\end{abstract}

Metaheaven (2012) e Bratton (2015) também empregam o termo cloud, ou nuvem, para se referirem principalmente a internet e aos agentes que a controlam, e defendem, que a rede mundial de computadores não espelha a realidade, pois não reflete a geografia política real, mas, colabora como ferramenta na reorganização de territórios e construção de novas geografias, possibilitando situações de superjurisdições. Estas últimas compreendem as maneiras pelas quais empresas transnacionais de tecnologia (ou nuvens), conseguem por

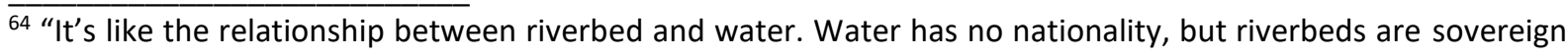
territories, we cannot allow polluted water from other nation-states to enter our country"

65 it was and is a conflict not only over the right to control search engine results, but indeed over the predominance of two different modes of sovereignty. The conflict pits a state that would dominate and determine the network sovereignty of information and energy flows versus a platform that would, by assembling users into another real network and imagined community, exceed, in deed if not letter, the last-instance sovereignty of the state and determine an alternate polity in its own image.
} 
meio da legislação e/ou ordens legais de seus países de origem, desafiar, exceder, transcender ou burlar a legislação dos outros Estados-nações em que também estão atuando. Em outras palavras, situações de super jurisdição implicam na reorganização dos limites políticos territoriais de Estados-nações ao longo do globo, (METAHEAVEN, 2012). As situações mais polêmicas relacionadas a super jurisdição, de acordo com Metaheaven (2012), se dão sob a imposição da jurisdição dos Estados Unidos a outros Estados-nações, por meio do USA Patriot Act, ou Ato Patriota Estadunidense, em livre tradução nossa. Trata-se de uma lei antiterrorismo que passou a vigorar em 2001 no Estado Americano. A lei autoriza o Departamento Federal de Investigação dos Estados Unidos - FBI, a exigir diretamente de qualquer instituição estadunidense - independentemente de onde quer que ela atue -, a divulgação de informações específicas sobre usuários, por meio da emissão de uma National Security Letter - NSL, ou Carta de Segurança Nacional, em livre tradução nossa. A questão crucial, segundo Metaheaven (2012), é que há situações em que o usuário que teve seus dados expostos pode nem ficar sabendo disso.

\begin{abstract}
"Depois que o Patriot Act foi assinado em lei, o número de cartas emitidas aumentou exponencialmente: de 8.500 em 2000 para 39.346 em 2003. Uma NSL inclui automaticamente uma ordem que proíbe o destinatário de notificar seus usuários sobre o pedido. O FBI só precisa afirmar que a informação procurada é 'relevante' para uma investigação. A pergunta crucial [...] 'As ordens do governo para divulgar os dados dos usuários estão sujeitos a revisão por um juiz?' - é respondida com 'sim' na Austrália, Canadá, Dinamarca, França, Alemanha, Irlanda, Japão, Espanha, Reino Unido e nos EUA. No entanto, nos EUA essa condição só é atendida se o provedor de nuvem, depois de receber a NSL, primeiro desafiar sua ordem de mordaça interna. Somente quando a NSL é aberta por um juiz, o provedor da nuvem pode informar ao usuário - alvo da NSL - sobre a existência da carta". (METAHEAVEN, 2012, p.5, tradução nossa) ${ }^{66}$.
\end{abstract}

Foi também sob a super jurisdição estadunidense, que se impôs sobre o território governado pelo ditador Hosni Mubarak, durante acontecimentos ocorridos em 2011, no Egito, que o "Facebook e o Twitter desempenharam o papel de mídia alternativa subversiva e não-

\footnotetext{
66 "After the Patriot Act was signed into law, the number of letters issued rose exponentially: from 8,500 in 2000 to 39,346 in 2003. An NSL automatically includes a gag order that prohibits the recipiente from notifying users about the request. The FBI need only assert that the information sought is "relevant" to an investigation. The crucial question [...] "Are government orders to disclose customer data subject to review by a judge?" is answered with "yes" in Australia, Canada, Denmark, France, Germany, Ireland, Japan, Spain, the United Kingdom, and the US. However, in the US this condition is only met if the cloud provider, after receiving the NSL, first challenges its built-in gag order. Only when the NSL is unsealed by a judge can the cloud provider inform the user about the existence of the letter."
} 
censurável -em parte porque os servidores desses serviços extremamente populares estavam além do alcance das autoridades locais" (METAHEAVEN, 2012, p.5, tradução nossa). ${ }^{67}$

Mais uma vez observa-se a ambivalência das redes, e o caráter multifacetado, mutável e complexo da cultura e das estéticas da vigilância, uma vez que a mesma combinação de dispositivos legais e tecnológicos, que segundo Metaheaven (2012), possui propensão histórica para o abuso, e está sendo usada para espionagem governamental sem causa específica legalmente justificada; também permitiu burlar a censura imposta por um governo ditatorial durante a Primavera Árabe. A esse respeito, Beiguelman (2016b, p.188) esclarece:

\begin{abstract}
sistemas de vigilância e controle contemporâneos trazem uma ambivalência estrutural: por serem distribuídos e pretenderem abarcar todas as nuances do tecido social, tornam-se vulneráveis a partir de algumas frestas pelas quais são feitos os ataques mais ou menos daninhos. Isso porque, apesar de serem construídas para tudo ver sem serem vistas, essas estruturas de vigilância e controle são sistemas em rede que, como tal, podem, ser haqueados, com o objetivo de dar visibilidade ao que pretendem esconder.
\end{abstract}

Firmino (2018, p.87-88) defende que "ao mesmo tempo em que um urbanismo inteligente alega controle total sobre uma cidade mais inteligente, formas de territorialização informais, imperceptíveis e impostas estão, silenciosamente, ocupando e segregando várias partes intraurbanas". O autor também afirma:

A definição de limites físicos ou digitais é uma característica fundamental de territórios, e quem define e controla a porosidade dessas fronteiras exercita o controle sobre o próprio território. Novas formas de territorialização precisam ser mais bem compreendidas em tempos de "vigilância líquida". (FIRMINO, 2018, p.88)

Desta maneira, compreendemos que os episódios citados, como o ocorrido no Egito e como a primeira guerra Sino-Googlesa de 2009, que também se dão no espaço híbrido e ampliado da cidade contemporânea, evidenciam o embaralhamento das atribuições entre governos e empresas, ao colocar ambos, como agentes da vigilância que disputam a soberania que permite demarcar limites em uma nova geografia política.

\footnotetext{
67 "Facebook and Twitter played the role of subversive, uncensorable alternative media - in part because the servers of these wildly popular services were beyond the reach of local authorities."
} 


\section{CONCLUSÕES E CONSIDERAÇÕES FINAIS}

O aprofundamento sobre as análises, reflexões e conceituações desenvolvidas por Santos (2006); Ferrara (2000); Duarte e Firmino, 2008, 2010; Bruno, Firmino e Kanashiro (2010); Lemos, 2010 e Beiguelman, 2016a, 2016b; sobre o espaço híbrido e ampliado da cidade contemporânea, tornou possível identificar, principalmente em casos noticiados pela imprensa brasileira, a implantação e o emprego de dispositivos tecnológicos de informação e comunicação, também em diversos espaços públicos das nossas cidades. Dentre eles, citamos no presente trabalho situações em: estacionamentos e túneis para tráfego de veículos, estádio de futebol, lojas de comercio de rua e de shoppings, mobiliário urbano (relógios, aspersores de água, abrigo de ônibus), museus, praias e no transporte público de pessoas. Esta investigação nos possibilitou tanto uma melhor compreensão de como as TICs aumentam as possibilidades das interações humanas, - principalmente por permitirem a adição de camadas informacionais, no espaço híbrido de materialidades, e relações sociais -; quanto um melhor entendimento de que, à medida que este processo se torna evidente, espaços híbridos e ampliados são constituídos também em cidades brasileiras (FERRARA, 2000; SANTOS, 2006; DUARTE; FIRMINO, 2008, 2010; BRUNO; FIRMINO; KANASHIRO, 2010; LEMOS, 2010; BEIGUELMAN, 2016a). Além disso, ao somarmos a compreensão a respeito de como as TICs funcionam e o que isso implica, conforme esclarecido por Beiguelman (2016a), Silveira (2017) e Han (2018); foi possível constatar que, ao capturarem e transmitirem continuamente nossos dados cotidianos, permitindo a interconexão entre os elementos intrínsecos da cidade, e entre a rede mundial de computadores, as TICs, além de contribuírem para a ampliação dos nossos espaços, também viabilizam no contexto brasileiro, a instauração da Internet das Coisas em uma escala de proporções urbanas (BEIGUELMAN, 2016a, 2018) ${ }^{68}$.

Com base nas ideais defendidas por Brighenti (2007) e Hatuka e Toch (2017), estendemos a noção de visibilidade para o campo sociológico, e compreendemos seus limites e assimetrias, identificando outros autores que trouxeram o exemplo da selfie como prática

\footnotetext{
${ }^{68} \mathrm{~A}$ instauração da Internet das Coisas em escala urbana foi um dos principais assuntos apresentados e desenvolvidos pela professora doutora Giselle Beiguelman ao longo das aulas da disciplina "DSG5013 - Arte e Design de Interface em Escala Urbana", ministradas de 13/03/2018 a 19/06/2018, no programa de pósgraduação Stricto Sensu em Design, na Faculdade de Arquitetura e Urbanismo da Universidade de São Paulo FAUUSP.
} 
de visibilidade usada com propósitos distintos, atendendo tanto às necessidades subjetivas de reconhecimento e representatividade, - como no bairro Cidade de Deus, entre outros, no Rio de Janeiro; e nas comunidades de Gurigica, São Benedito e Itararé, na cidade de Vitória, ES -; quando de autopromoção social, - como no caso retratado pelo documentário do cineasta Marcelo Pedroso. (BRUNO; FIRMINO; KANASHIRO, 2010; FELDMAN, 2011; RICARDO, 2011; BRUNO, 2013; BEIGUELMAN, 2016a, 2016b; CRARY, 2016; SIBILIA, 2016; BRUNO et al., 2018). Uma outra situação identificada, relacionada às condições de assimetria da visibilidade, a partir da pesquisa de Bruno (2018), nos permitiu mostrar que o fenômeno também tem sido imposto a cidadãos, em territórios urbanos, pelo poder público brasileiro, como no caso do Centro de Operações da prefeitura do Rio de Janeiro.

Com apoio nas definições de Bruno (2013) e Virilio (2012), baseadas principalmente em Foucalt (1983), sobre o conceito, e sobre como funciona a vigilância distribuída - que é heterogênea, diversificada, e alimentada fundamentalmente pelos rastros digitais da movimentação de seus sujeitos -, pudemos entender que principalmente por meio do compartilhamento de dados on-line, espaços de visibilidade e/ou de exposição de pessoas, também se tornam potenciais espaços de vigilância. Além disso, observamos com o trabalho de Bruno (2013), os dois elementos-chaves dos processos de vigilância, que serviram como diretriz para agrupar as principais situações identificadas de captura de dados, por parte do poder público brasileiro, em dois grandes grupos: dos casos que estavam mais relacionadas ao olhar sobre que se vigia; e dos que se relacionavam mais às informações sobre o que se vigia.

Ao identificarmos e analisarmos situações de captura de dados com emprego das TICs, também por parte do poder público brasileiro, à luz de discussões pautadas por algumas de suas possibilidades de implicações, (como: geração de informações para melhoria da governança pública; ameaças à privacidade, encolhimento da esfera pública, discriminação racial e de gênero, exclusão social, viés tecnológico, e monetização de dados pessoais); levantadas por autores que pesquisam as referidas situações identificadas, ou que possuem pesquisas sobre temas relacionados a elas, - como principalmente: Koskella (2010), Virilio (2012), Machado, Ortellado e Ribeiro (2016), Moll e Parizot (2016), Silveira (2017), Abreu, Lago e Massaro (2018a, 2018b, 2018c), Avelino, Silveira e Souza (2018), Bruno et al. (2018), Buolamwini e Gebru (2018), Keyes (2018) e Zuboff (2018) -; foi possível aprofundar o 
entendimento a respeito da vigilância em programas tecnológicos de governos, e identificar sua condição estruturalmente ambivalente (BEIGUELMAN, 2016b).

Tendo como alicerce principal a pesquisa de Lyon (2018), sobre cultura da Vigilância, e as pesquisas de Bruno e Lins (2010), e Beiguelman (2016a, 2016b), que também abrangem suas estéticas, compreendemos sua condição multifacetada, mutável e complexa, mas ainda assim, identificamos no trabalho destes autores aspectos que permitiram caracterizar este fenômeno.

As pesquisas sobre as Smat cities, desenvolvidas por Goospeed (2014), Rozestraten (2016), Rennó (2016), Greenfield (2017) e Figueiredo (2018), nos trouxeram definições e caracterizações sobre tal conceito de cidade. Além disso, nos possibilitaram estabelecer analogias, com situações identificadas, de captura de dados com emprego das TICs, também por parte do poder público brasileiro - que em contextos diversos podem servir tanto a vigilância e ao controle; como ao impedimento de censuras em governos autoritários (METAHEAVEN, 2012; BEIGUELMAN, 2016b). A análise de tais situações, nos permitiu também identificar conflitos entre agentes da vigilância, no espaço híbrido e ampliado da cidade - ou do mundo -, contemporânea(o), que disputam soberanias em escalas territoriais físicas e informacionais diversas, delineando novas geografias políticas. (METAHEAVEN, 2012; BRATTON, 2015; BEIGUELMAN, 2016b, 2019; FIRMINO, 2018). Desta maneira, elencamos a seguir considerações finais que complementam as conclusões deste trabalho de pesquisa:

1) Embora via de regra, a adesão à visibilidade, ou à grande parte dela, seja voluntária, e chega até a ser desejada por um grande número de pessoas, (BRUNO, 2013; SIBILIA, 2016), entendemos que a adesão à vigilância, geralmente não é. (BRIGHENTI, 2007; HATUKA; TOCH, 2017; BRUNO et al., 2018).

2) A visibilidade não está necessariamente ligada de maneira direta ao monitoramento, ou à vigilância, - nem à autopromoção, ou ao reconhecimento -, todas estas, e outras, implicações e desdobramentos fazem parte de sua condição multifacetada. (BRIGHENTI, 2007; BRUNO, 2013; BEGUELMAN, 2016b; LYON, 2018). Constatamos que é principalmente na sua condição assimétrica que a visibilidade facilita a vigilância. (BRIGHENTI, 2007; VIRILIO, 2012; HATUKA; TOCH, 2017; BRUNO et al, 2018; AVELINO; SILVEIRA; SOUZA, 2018; ZUBOFF, 2018). 
3) O relatório anual do Instituto AI Now, da Universidade de Nova York nos Estados Unidos, um dos primeiros centros universitários de pesquisa com foco específico no significado e implicações sociais da Inteligência Artificial no mundo -, nos mostrou que governos têm implantado tecnologias de reconhecimento biométrico (que também englobam reconhecimento facial), e se preocupado com as questões de privacidade, discriminação e vigilância associados a elas, em regiões como: Europa, Austrália nos mais diversos setores como ensino, habitação, transporte, saúde, policiamento, entre outros - a uma taxa mais rápida do que a regulamentam. E pudemos constatar que no contexto brasileiro o cenário não é diferente, uma vez que também existem situações em que o poder público brasileiro (em parceria ou não com empresas privadas) está coletando e usando dados digitais de cidadãos, sem a necessária regulamentação, ou prestação de contas para com a população, isto é: sem esclarecer quais dados estão sendo coletados, de quem exatamente, de que maneira estão sendo usados e quem tem acesso a eles. (MACHADO; ORTELLADO; RIBEIRO, 2016; SILVEIRA, 2017; ABREU; LAGO; MASSARO, 2018a, 2018b, 2018c; BRUNO et al., 2018; DERECHOS DIGITALES, 2018).

4) Constatamos que as situações identificadas de captura de dados por parte de governos (inclusive brasileiro), com emprego das TICs no espaço híbrido e ampliado de cidades contemporâneas, são ambíguas, e fazem parte de uma condição complexa, ambivalente e mutável (BRIGHENTI, 2007; BRUNO, 2013; BEGUELMAN, 2016b; LYON, 2018), pois, podem contribuir tanto para acentuar estigmatização, discriminação de gênero ou exclusão social (como no caso do Programa de Monitoramento Virtual da Fronteira do Texas), quanto contribuir para o cumprimento da justiça (como nos casos mencionados das investigações realizadas pela polícia de Boston e do Rio de Janeiro); também podem não só contribuir para a prevenção de riscos à saúde pública (como no caso do SINAN), mas também podem servir à vigilância que ameaça o direito à privacidade, e contribui para o encolhimento da esfera pública (como no caso da Linha-4 Amarela do metrô de São Paulo). Os limites para a captura de dados são flexíveis, seus contextos são extremamente diversos, e seu emprego é ambivalente. As tecnologias por si só não são responsáveis por causar estigmatização, preconceito ou exclusão social, mas sim a maneira pela qual tais tecnologias são desenvolvidas e empregadas, (SIBILIA, 2016; ZUBOFF, 2018). Dito de outra maneira, um dos caminhos para ações possíveis a favor de espaços mais inclusivos, talvez não seja destruir câmeras de vídeo 
vigilância (que podem sim contribuir para otimização de processos de identificação e controle de acessos), mas, empregá-las de maneira regulamentada e ética, com transparência por parte do poder público, e com participação da população civil em discussões prévias a sua implementação em espaços públicos urbanos. (RENNÓ, 2016; BEIGUELMAN, 2016a, 2016b).

5) Principalmente a partir da compreensão do funcionamento do mercado de dados, e de considerarmos casos emblemáticos como as revelações de Snowden, ou o escândalo da Cambridge Analytica envolvendo o Facebook, no contexto do capitalismo de vigilância (AVELINO; SILVEIRA; SOUZA, 2018; SILVEIRA, 2017; ZUBOFF, 2018), foi possível observar que processos de modulação e consequentemente, monetização de dados de cidadãos, também chegaram a ser implantados, com emprego das TICs, em espaços urbanos públicos, como no caso do sistema de reconhecimento facial da Linha-4 Amarela do metrô de São Paulo, que permaneceu em funcionamento por curto período de tempo - por volta de abril a agosto de 2018. Entende-se que uma vez que tais dados podem ser monetizados, "devemos ampliar a discussão entre os distintos atores que participam da cidade, sobre como estes dados são utilizados e o respectivo aparato legal necessário para garantir a privacidade e segurança dos cidadãos." (RENNÓ, 2016, p.21-22).

6) Os aspectos preponderantes comuns identificados na cultura da vigilância a partir principalmente das ideias defendidas por Lyon (2018) e Bruno (2013), foram: a) participação crescente dos sujeitos na vigilância, principalmente por meio de mídias sociais online, e pelo imperativo social contemporâneo de compartilhamento de dados pessoais (que também pode ser encarado como um aspecto da auto exposição por parte de indivíduos que desejam a visibilidade); b) aceitação da vigilância sem questionamento por parte das pessoas, justificada na maioria das vezes pelo medo, familiaridade, entretenimento, ou até mesmo dificuldade para identifica-la ou recusá-la; c) legitimação da vigilância divididos em três campos principais: por aspectos de visibilidade da vida cotidiana dos indivíduos e em suas relações sociais; por discursos de securitização; e pela lógica da eficácia (que requer o emprego da tecnologia que potencializa a vigilância).

7) Principalmente ao traçarmos analogias entre a conceituação das Smart Cities (GOODSPEED, 2014; BEIGUELMAN, 2016b; ROZESTRATEN, 2016; RENNÓ, 2016; GREENFIELD, 2017; 
FIGUEIREDO, 2018), e os casos identificados de captura de dados com emprego das TICs por parte de governos (inclusive brasileiro), foi possível identificar como se dá a construção de novas geografias, em escalas diversas, que envolvem conflitos no espaço híbrido e ampliado da cidade contemporânea, entre agentes da vigilância, que disputam soberanias sobre territórios físicos e informacionais diversos. (METAHEAVEN, 2012; BRATTON, 2015; BEIGUELMAN, 2016a, 2016b; FIRMINO, 2018).

Por fim, também é importante considerarmos, que ao nos preocuparmos com a captura de dados no espaço híbrido e ampliado da cidade contemporânea, geralmente não são as particularidades de cada dado, sobre cada indivíduo, que mais importam aos agentes da vigilância, nem mesmo o conjunto específico de dados de um único individuo em particular - a não ser que seja algo notadamente fora do padrão (AVELINO; SILVEIRA; SOUZA, 2016, 2018; BIRCHALL, 2017; SILVEIRA, 2017; ZUBOFF, 2018). O que mais importa a tais agentes, na maioria das vezes, são os cruzamentos de diversos conjuntos de dados de inúmeros indivíduos, que ao serem analisados, serão interpretados como novas informações ou maneiras de medição e controle, ou modulação, relacionados a um determinado perfil de indivíduos ou a uma ampla varredura em massa. (AVELINO; SILVEIRA; SOUZA, 2016, 2018; BIRCHALL, 2017; SILVEIRA, 2017; ZUBOFF, 2018). O dado é relacional, e isto é um dos aspectos que lhe agrega valor. Desta maneira, Birchall (2017, p.28, tradução nossa) ${ }^{69}$, afirma: "somos ruídos, não sinal”. Dito de outra forma, a autora aponta para outra importante implicação relacionada à captura de dados pessoais dos cidadãos, por parte do poder público, trata-se da maneira pela qual determinados governos enxergam seus cidadãos: "eles não são considerados agentes políticos formados dignos de nada mais do que reforçar um algoritmo para análise de dados". (BIRCHALL, 2017, p.28, tradução nossa) ${ }^{70}$.

De acordo com Kuster e Pechman (2014), a esfera pública é complexa e mutável, se constitui em função do indivíduo, e é reflexo de nossa sociedade. Portanto, se as práticas de visibilidade, os espaços, e as relações humanas estão sendo alteradas pelo emprego das TICs, a esfera pública também será alterada (KUSTER; PECHMAN, 2014; WISNIK, 2018). Segundo

\footnotetext{
69 "We are noise, not signal”

70 "they are not considered fully formed political agents worthy of anything more than bolstering an algorithm for data analysis".
} 
estes autores, o poder da cidade é "de produzir relações, de obrigar à negociação, de acolher o conflito. É o poder de ser o lugar da esfera pública, mas não só o lugar, é a própria condição de existência dela" (KUSTER; PECHMAN, 2014, p.19). Ou seja, a esfera pública se encolhe, e a cidade vai deixando de ser cidade, à medida que se torna excludente, à medida que não abriga mais a diversidade.

Como podemos constatar, a investigação da presente pesquisa não se limita somente aos aspectos físicos e tecnológicos de dispositivos e sistemas de vigilância presentes, ou sendo implantados em nossos espaços públicos urbanos. Mas também se debruça sobre seus aspectos, e contextos, socioeconômicos e culturais. Pois, compreende-se que o espaço é híbrido, pode ser ampliado, e que não existe cidade quando se dissocia suas características físicas e sociais intrínsecas. Desta forma, percebe-se, que cabe a nós, arquitetos, ampliar constantemente nosso campo de visão, de maneira a nos permitir atuar de maneira multidisciplinar. Neste sentido, Maluf (2008), tece considerações a respeito de nosso papel profissional:

$\mathrm{O}$ arquiteto surge como agente instrumentalizador desse espaço por sua capacidade de compreensão espacial, mais que de representação projetual. É, antes de um agente modificador, um leitor da sociedade em que vive [...] Sozinho, não se configura como instrumento apto a alterar ou dirimir as contradições do espaço inerentes às relações sociais em vigor. (MALUF, 2008, p. 82-83)

À medida que sistemas de vigilância têm integrado o espaço urbano, entende-se que é preciso aproveitar a atual oportunidade histórica de apropriação da tecnologia a favor da sociedade. E neste sentido, espera-se que a discussão sobre o assunto do presente trabalho possa encontrar terreno fértil em outros estudos futuros com temas relacionamos, principalmente no que tange às relações entre público e privado, para que se abram possibilidades de buscarmos lógicas não excludentes para a construção ou (re)apropriação espacial em nossas cidades, e para que, em última instância, de acordo com Kuster e Pechman (2014), seja possível defender a própria urbanidade. 


\section{REFERENCIAS ${ }^{71}$}

ABREU, J. S.; LAGO, L.; MASSARO, H. Especial: As "permissões" de acesso a dados em apps do governo. InternetLab, [S.I.]., 21 maio 2018a. Disponível em: $<$ https://www.internetlab.org.br/pt/privacidade-e-vigilancia/especial-as-permissoes-deacesso-dados-em-apps-do-governo/>. Acesso em: 28 jan. 2020.

Especial: As políticas de privacidade de apps do governo. InternetLab, [S.I.]., 21 maio 2018b. Disponível em: <http://www.internetlab.org.br/pt/privacidade-evigilancia/especial-as-politicas-de-privacidade-de-apps-do-governo/>. Acesso em: 28 jan. 2020.

Especial: A obtenção do consentimento sobre tratamento de dados. InternetLab, [S.I.]., 21 maio 2018c. Disponível em: <http://www.internetlab.org.br/pt/privacidade-e-vigilancia/especial-obtencao-doconsentimento-sobre-tratamento-de-dados/>. Acesso em: 28 jan. 2020.

AFFONSO, C. A privacidade saiu dos trilhos no metrô de São Paulo. Tecfront, [São Paulo], 18 abr. 2018a. Disponível em: <https://tecfront.blogosfera.uol.com.br/2018/04/18/aprivacidade-saiu-dos-trilhos-no-metro-de-sao-paulo/>. Acesso em: 24 abr. 2018.

Impressão digital é chave que não se perde, e proteção de dados requer rigor. Folha de São Paulo, [São Paulo], 13 jun. 2018b. Disponível em: $<$ https://www1.folha.uol.com.br/cotidiano/2018/06/impressao-digital-e-chave-que-nao-seperde-e-protecao-de-dados-requer-rigor.shtml>. Acesso em: 01 jan. 2020.

AKA, J. "The Father of China's Great Firewall" Re-defines Internet Sovereignty. 88BAR, [China], 24 nov. 2011. Disponível em: <https://88-bar.com/2011/11/the-father-of-chinasgreat-firewall-re-defines-internet-sovereignty/\#s>. Acessos em: 17 fev. 2020.

ALMEIDA, E. Homem é preso por engano em Copacabana. Band News, [Rio de Janeiro], 24 jul. 2019. Disponível em: <https://bandnewsfmrio.com.br/editorias-detalhes/homem-epreso-por-engano-em-copacabana>. Acesso em: 21 jan. 2020.

AMARAL, P. V. M. et al. Zika virus infection and microcephaly: Evidence regarding geospatial associations. [S.I.]: PLOS Neglected Tropical Diseases, 2018, V.12, 16p. Disponível em: $<$ https://journals.plos.org/plosntds/article?id=10.1371/journal.pntd.0006392>. Acesso em: 17 jul. 2019.

ANAC. "Bastão de selfie" pode ser transportado na bagagem de mão. Agência Nacional de Aviação Civil (ANAC), Brasília, DF, 26 jan. 2015. Disponível em: <https://www.anac.gov.br/noticias/2015/201cbastao-de-selfie201d-pode-ser-transportadona-bagagem-de-mao>. Acesso em: 29 dez. 2019.

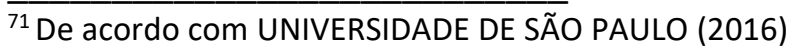


AVELINO, R; SILVEIRA. S. A; SOUZA, J. (Orgs.). A sociedade de controle: manipulação e modulação nas redes digitais. São Paulo: Hedra, 2018.

AVELINO, R; SILVEIRA. S. A; SOUZA, J. A privacidade e o mercado de dados pessoais. In: Machado, J.; Ortellado, P.; Ribeiro, M. (Orgs.). Privacidade e vigilância nos meios digitais. [Rio de Janeiro]: Liinc em Revista, nov. 2016, v.12, n.2, p.217-230. Disponível em: <http://revista.ibict.br/liinc/article/view/3719/3138>. Acesso em: 28 fev. 2019.

BAMBOZZI, L. Do invisível ao redor: arte e espaço informacional. 2019. 231 p. Tese de doutorado (Arquitetura e Urbanismo) - Faculdade de Arquitetura e Urbanismo, Universidade de São Paulo, São Paulo, 2019.

BARCELLOS, C. et al. The Zika Virus Epidemic in Brazil: From Discovery to Future Implications. [S.I.]: International Journal of Environmental Research and Public Health, 2018, v. 15, 18p. Disponível em: <https://www.mdpi.com/1660-4601/15/1/96/htm>. Acesso em: 17 jul. 2019.

BBC. Entenda o escândalo de uso político de dados que derrubou valor do Facebook e o colocou na mira de autoridades. BBC [S.I.]., 20 mar 2018. Disponível em: <https://www.bbc.com/portuguese/internacional-43461751>. Acesso em: 01 fev. 2020.

BEIGUELMAN, G. Da cidade interativa às memórias corrompidas: arte, design e patrimônio histórico na cultura urbana contemporânea. 2016. 303 p. Tese de Livre-docência (Arquitetura e Urbanismo) - Departamento de História da Arquitetura e Estética do Projeto, Faculdade de Arquitetura e Urbanismo, Universidade de São Paulo, São Paulo, 2016a.

Cidades de código aberto: arte, arquitetura e design no espaço informacional. In: COLÓQUIO INTERNACIONAL IMAGINÁRIO, CONSTRUIR E HABITAR A TERRA, 1., 2016, São Paulo. Atas... São Paulo: FAUUSP, 2016b. p. 179-190.

Memória da Amnésia: políticas do esquecimento. São Paulo: Edições Sesc São Paulo, 2019.

BENJAMIN, R. (Ed.) Captivating Technology Race, Carceral Technoscience, and Liberatory Imagination in Everyday Life. Durham, NC: Duke University Press, 2019.

BeRger, P. Motorists Can Now Acess Waze App Directions in New York Tunne. The Wall Street Journal, [New York City], 29 jan. 2019. Disponível em: <https://www.wsj.com/articles/motorists-can-now-access-waze-app-directions-in-new-yorktunnels-11548777601>. Acesso em: 06 nov. 2019.

BIONI, B. R; MACHADO, J. A proteção de dados pessoais nos programas de Nota Fiscal: um estudo de caso do "Nota Fiscal paulista". In: Machado, J.; Ortellado, P.; Ribeiro, M. (Orgs.). Privacidade e vigilância nos meios digitais. [Rio de Janeiro]: Liinc em Revista, nov. 2016, v.12, n.2, p.350-364. Disponível em: <http://revista.ibict.br/liinc/article/view/3734/3146>. Acesso em: 28 fev. 2019. 
BIONI, B. Expansão do Wi-Fi público às "custas" de dados pessoais. Jota, [São Paulo], 17 jul. 2017. Disponível em: <https://www.jota.info/paywall?redirect_to=//www.jota.info/opiniaoe-analise/colunas/agenda-da-privacidade-e-da-protecao-de-dados/expansao-do-wi-fipublico-as-custas-de-dados-pessoais-17072017>. Acesso em: 28 jan. 2020.

BIRCHALL, C. Shareveillance: The Dangers of Openly Sharing and Covertly Collecting Data. Minneapolis: University of Minnesota Press, 2017.

BLIMAN, P. et al. Epidemiological data accessibility in Brazil. [S.I.]: The Lancet Infectious Diseases, apr. 2016, v.16 p. 524-525. Disponível em: <https://www.thelancet.com/journals/laninf/article/PIIS1473-3099(16)30007-X/fulltext>.

Acesso em: 17 jul. 2019.

BORCHERS, C. Boston mayor sharply rebukes Haystack parking app. The Boston Globe, [Boston], 15 july, 2014.2 Disponível em: <https://www.bostonglobe.com/business/2014/07/15/haystack/ceD8Rcmz2PRd39Gp58gwh O/story.html>. Acesso em: 06 nov. 2019.

BOTELLO, N. An orchestration of electronic surveillance: a CCTV experience in Mexico. International Criminal Justice Review, 2007, v.17, n.4, p.325-335. Disponível em: <https://journals.sagepub.com/doi/pdf/10.1177/1057567707311566>. Acesso em: 28 jan. 2019.

BRASIL. Lei no 5.534 de 14 de novembro de 1968. Dispõe sobre a obrigatoriedade de prestação de informações estatísticas e dá outras providências. Presidência da República, Casa Civil, Subchefia para Assuntos Jurídicos, Brasília, DF, nov. 1968. Disponível em: <http://www.planalto.gov.br/ccivil_03/leis/L5534.htm>. Acesso em: 06 nov. 2019.

. Portaria no 4 de 28 de setembro de 2017. Consolidação das normas sobre os sistemas e os subsistemas do Sistema Único de Saúde. Ministério da Saúde, Brasília, DF, 28 set. 2017.2 Disponível em: <http://bvsms.saude.gov.br/bvs/saudelegis/gm/2017/prc0004_03_10_2017.html>. Acesso em 20 jan. 2020.

Deliberação no 167 de 30 de janeiro de 2018. Altera a Resolução CONATRAN no 598, de 24 de maio de 2016, que regulamenta a produção e a expedição da Carteira Nacional de Habilitação, com novo leiaute e requisitos de segurança. Conselho Nacional de Trânsito (CONATRAN), Brasília, DF, 30 jan. 2018. Disponível em: < https://infraestrutura.gov.br/images/Deliberacoes/Deliberacao1672018.pdf>. Acesso em: 06 nov. 2019.

Lei no 13.709 de 14 de agosto de 2018. Lei Geral de Proteção de Dados Pessoais (LGPD). Presidência da República, Secretaria-Geral, Subchefia para Assuntos Jurídicos, Brasília, DF, 15 ago. 2018. Disponível em: <http://www.planalto.gov.br/ccivil_03/_ato2015-2018/2018/lei/L13709.htm> Acesso em: 06 nov. 2019. 
BRATTON, B. H. The stack: on software and sovereignty. Cambridge, Mass.: The MIT Press, 2015.

BRIGHENTI, A. Visibility: a category for the social science. [S.I.]: Current Sociology, may, 2007, v. 55, n. 3, p. 323-342. Disponível em: <https://journals.sagepub.com/doi/10.1177/0011392107076079>. Acesso em: 24 abr. 2018.

BROWNE, S. Dark Matters on the Surveillance of Blackness. Durham, NC: Duke University Press, 2015.

BRUNO, F; FIRMINO R; KANASHIRO, M; (Orgs.). Vigilância e visibilidade: espaço, tecnologia e identificação. Porto Alegre: Sulina, 2010.

BRUNO, F. Máquinas de ver, modos de ser: vigilância, tecnologia e subjetividade. Porto Alegre: Sulina, 2013.

. Visões maquínicas da cidade maravilhosa: do centro de operações do Rio à Vila Autódromo. In: Bruno, F; Cardoso, B; Guilhon, L; Kanashiro, M. \& Melgaço, L. (Orgs.). Tecnopolíticas da vigilância: perspectivas periféricas. São Paulo: Boitempo, 2018, p.239-256.

BRUNO, F. et al. (Org.). Tecnopolíticas da vigilância: perspectivas periféricas. São Paulo: Boitempo, 2018

BRUNO, F; LINS, C. Práticas artísticas e estéticas da vigilância. In: Bruno, F; Kanashiro, M; Firmino, R. (Orgs.). Vigilância e visibilidade: espaço, tecnologia e identificação. Porto Alegre: Sulina, 2010, p. 211-222.

BUOLAMWINI, J; GEBRU, T. Gender Shades: Intersectional Accuracy Disparities in Commercial Gender Classification. In: CONFERENCE ON FAIRNESS, ACCOUNTABILITY, AND TRANSPARENCY, 1, 2018, New York, NY. Proceedings... New York, NY: PMLR, 2018, 15 p. Disponível em: <http://proceedings.mlr.press/v81/buolamwini18a.html>. Acesso em: 06 nov. 2019.

CADWALLADR, C.; CONFESSORE, N.; ROSENBERG, M. How Trump Consultants Exploited the Facebook Data of Millions. The New York Times, London, 17 mar, 2018. Disponível em: <https://www.nytimes.com/2018/03/17/us/politics/cambridge-analytica-trumpcampaign.html>. Acesso em: 01 fev. 2020.

CANALTECH. Waze trará beacons para navegação em túneis no Rio de Janeiro. Canaltech, [Rio de Janeiro], 21 set. 2016. Disponível em: <https://canaltech.com.br/produtos/wazetrara-beacons-para-navegacao-em-tuneis-no-rio-de-janeiro-80611/>. Acesso em: 06 nov. 2019.

CARVALHO, I. Aplicativos permitem compartilhar vagas de garagem. Exame, [São Paulo], 22 mar. 2016. Disponível em: <https://exame.abril.com.br/seu-dinheiro/aplicativos-permitemcompartilhar-vagas-de-garagem/>. Acesso em 06 nov. 2019. 
CEARÁ (Estado). Lei no 15.951 de 14 de janeiro de 2016. Institui o Bilhete Único Metropolitano no Sistema de Transporte Público Coletivo Intermunicipal de Passageiros na Região Metropolitana de Fortaleza. Palácio da Abolição, do Governo do Estado do Ceará, Fortaleza, CE, 14 jan. 2016. Disponível em: <https://belt.al.ce.gov.br/index.php/legislacao-doceara/organizacao-tematica/viacao-transportes-desenvolvimento-urbano/item/3557-lei-n15-951-de-14-01-16-d-o-18-01-16>. Acesso em 06 nov. 2019.

CHIARA, M. D. São Paulo já tem supermercado sem operador de caixa; veja como funciona. Estadão, [São Paulo], 06 maio, 2019. Disponível em: <https://economia.estadao.com.br/noticias/geral,sao-paulo-ja-tem-supermercado-semoperador-de-caixa,70002817055>. Acesso em: 06 nov. 2019.

COMITÊ GESTOR DA INTERNET NO BRASIL. TIC governo eletrônico 2017: Pesquisa sobre o uso das tecnologias de informação e comunicação no setor público brasileiro. São Paulo: Comitê Gestor da Internet no Brasil, 2018. Disponível em: <https://www.cetic.br/media/docs/publicacoes/2/TIC_eGOV_2017_livro_eletronico.pdf>. Acesso em: 06 nov. 2019.

COMPANHIA DO METROPOLITANO DE SÃO PAULO, Metrô compra sistema de monitoramento eletrônico com reconhecimento facial. Metrô, [São Paulo], 28 jun. 2019. Disponível em: <http://www.metro.sp.gov.br/noticias/28-06-2019-metro-compra-sistemade-monitoramento-eletronico-com-reconhecimento-facial.fss>. Acesso em: 06 nov. 2019.

CONFESSORE, N.; HAKIM, D. Data Firm Says 'Secret Sauce' Aided Trump; Many Scoff. The New York Times, [S.I.]., 06 mar, 2017. Disponível em: <https://www.nytimes.com/2017/03/06/us/politics/cambridge-analytica.html>. Acesso em: 01 fev. 2020.

CONVERGENCIA DIGITAL. Idec processa metrô de SP em R\$ 100 milhões por coleta ilegal de dados. Convergência Digital, [São Paulo], 31 ago. 2018. Disponível em: <http://www.convergenciadigital.com.br/cgi/cgilua.exe/sys/start.htm?UserActiveTemplate= site\&infoid=48862\&sid=18>. Acesso em: 13 dez. 2019.

CRARY, J. 24/7 Capitalismo tardio e os fins do sono. São Paulo: Ubu Editora, 2016.

CRAWFORD, K. et al., AI Now 2019 Report. New York: Al Now Institute, 2019. 100 p. Disponível em: <https://ainowinstitute.org/Al_Now_2019_Report.html>. Acesso em: 01 fev. 2020.

CRISTINA. A. Novas portas da Linha 4 Amarela contam com reconhecimento facial. Jornal da USP, [São Paulo], 19 abr. 2018. Disponível em: <https://jornal.usp.br/atualidades/novasportas-da-linha-4-amarela-contam-com-reconhecimento-facial/>. Acesso em: 24 abr. 2018.

DANTAS, D.; DANTAS, T. Doria oferece dados de usuários do Bilhete Único à iniciativa privada. O Globo, [São Paulo], 17 fev. 2017. Disponível em: <https://oglobo.globo.com/brasil/doria-oferece-dados-de-usuarios-do-bilhete-unicoiniciativa-privada-20942133>. Acesso em: 28 jan. 2020. 
DERECHOS DIGITALES. Hacking Team na América Latina. In: Bruno, F; Cardoso, B; Guilhon, L; Kanashiro, M. \& Melgaço, L. (Orgs.). Tecnopolíticas da vigilância: perspectivas periféricas. São Paulo: Boitempo, 2018, p.417-422.

DIAS, E. Lojas sem vendedor usam a tecnologia para vender produtos em Vitória. CBN Vitória, [Vitória], 082 jan. 2018.2 Disponível em: <https://www.gazetaonline.com.br/cbn_vitoria/reportagens/2018/01/lojas-sem-vendedorusam-a-tecnologia-para-vender-produtos-em-vitoria-1014114045.html>. Acesso em: 06 nov. 2019.

DINIZ, C. Decreto determina bilhete eletrônico como único meio de pagamento em transporte público de Manaus. G1, Amazonas, [Manaus], 20 set. 2019. Disponível em: <https://g1.globo.com/am/amazonas/noticia/2019/09/20/decreto-determina-bilheteeletronico-como-unico-meio-de-pagamento-em-transporte-publico-de-manaus.ghtml>. Acesso em: 06 nov. 2019.

DOUGHERTY, C. Google photos mistakenly labels black people 'Gorillas'. The New York Times, [S.I.]., 1 jul. 2015. Disponível em: <https://bits.blogs.nytimes.com/2015/07/01/googlephotos-mistakenly-labels-black-people-gorillas/>. Acesso em: 22 fev. 2019.

DUARTE, F.; FIRMINO, R. Cidade infiltrada, espaço ampliado: as tecnologias de informação e comunicação e as representações das espacialidades contemporâneas. Arquitextos, Vitruvius, [São Paulo], ano 08, n. 096.01, maio 2008. Disponível em: <https://www.vitruvius.com.br/revistas/read/arquitextos/08.096/3408>. Acesso em: 24 abr. 2018.

Espaço, visibilidade e tecnologias: (Re)caracterizando a experiência urbana. In: Bruno, Fernanda; Kanashiro, Marta e Firmino, Rodrigo. (Orgs.). Vigilância e visibilidade: espaço, tecnologia e identificação. Porto Alegre: Sulina, 2010, p. 94-112.

ELER, G. A discussão sobre direito à imagem no metrô de SP. Nexo, [São Paulo], 13 set. 2018. Disponível em: <https://www.nexojornal.com.br/expresso/2018/09/13/A-discuss\%C3\%A3osobre-direito-\%C3\%A0-imagem-no-metr\%C3\%B4-de-SP>. Acesso em: 19 nov. 2018

EVANGELISTA, S.; POLIVANOV, B. Construções Identitárias Periféricas na Rede: as it Girls das Favelas Cariocas no Instagram. In: CONGRESSO BRASILEIRO DE CIÊNCIAS DA COMUNICAÇÃO, 39., 2016, evento componente: GP Cibercultura, Encontro dos Grupos de Pesquisas em Comunicação, 16., 2016, São Paulo. Anais... São Paulo: Intercom, 2016. 15 p.

EVANGELISTA, R. A. et al. DIO: o mapeamento coletivo de câmeras de vigilância como visibilização da informatização do espaço urbano. In: Bruno, F; Cardoso, B; Guilhon, L; Kanashiro, M. \& Melgaço, L. (Orgs.). Tecnopolíticas da vigilância: perspectivas periféricas. São Paulo: Boitempo, 2018, p.395-412.

FÁBIO, A. C. Por que São Paulo revogou o serviço que usa dados sigilosos do RG. Nexo, [São Paulo], 15 jun. $2018 . \quad$ Disponível 
<https://www.nexojornal.com.br/expresso/2018/06/15/Por-que-S\%C3\%A3o-Paulo-revogouo-servi\%C3\%A7o-que-usa-dados-sigilosos-do-RG>. Acesso em: 01 jan. 2020.

. Onde o reconhecimento facial foi banido nos EUA. E a situação no Brasil. Nexo, [S.I.]., 26 jul. 2019. Disponível em: <https://www.nexojornal.com.br/expresso/2019/07/26/Onde-o-reconhecimento-facial-foibanido-nos-EUA.-E-a-situa\%C3\%A7\%C3\%A3o-no-Brasil>. Acesso em: 06 nov. 2019.

FARIAS. A. Justiça proíbe uso de câmeras de reconhecimento facial no Metrô. Veja São Paulo, [São Paulo\}, 15 set. 2018. Disponível em: <https://vejasp.abril.com.br/cidades/justica-proibeuso-de-cameras-de-reconhecimento-facial-no-metro/>. Acesso em: 13 dez. 2019.

FAUSTINO, R. Waze no Brasil e no mundo: como o app cresce se relacionando com pessoas, empresas e governos. Época negócios, [S.I.]., 15 abr. 2019. Disponível em: <https://epocanegocios.globo.com/Tecnologia/noticia/2019/04/waze-no-brasil-e-nomundo-como-o-app-cresce-se-relacionando-com-pessoas-empresas-e-governos.html>. Acesso em: 03 dez. 2019.

FÁVERO, B. Caso Marielle é exemplo de como a tecnologia pode ajudar a solucionar crimes. Folha de São Paulo, Rio de Janeiro. 15 mar. 2019. Disponível em: <https://www1.folha.uol.com.br/cotidiano/2019/03/caso-marielle-e-exemplo-de-comotecnologia-pode-ajudar-a-solucionar-crimes.shtml>. Acesso em 10 fev. 2020.

FELDMAN, I. Do declínio da intimidade aos novos regimes de visibilidade In: Predoso, Marcelo. (Coord.). Pacific: textos para debate. Recife: Edição André Antônio, 2011, p. 9-15.

FERRARA, L. Os significados urbanos. São Paulo: Editora da Universidade de São Paulo: Fapesp, 2000.

FIGUEIREDO, G. M. P. Cidades inteligentes no contexto brasileiro: a importância de uma reflexão crítica. In: ENCONTRO DA ASSOCIAÇÃO NACIONAL DE PESQUISA E PÓS-GRADUÇÃO EM ARQUITETURA E URBANISMO, 4., 2016, Porto Alegre. Anais... Porto Alegre: PROPAR/UFRGS, 2016. 14 p.

O discurso e a prática da Smart City: perspectivas críticas e aproximação sistemáticas no contexto de metrópoles latino-americanas. 2018, 156 p. Dissertação de mestrado (Arquitetura e Urbanismo) - Faculdade de Arquitetura e Urbanismo, Universidade de São Paulo, São Paulo, 2018.

FIRMINO, R. Securitização, vigilância e territorialização em espaços públicos na cidade neoliberal. In: Bruno, F; Cardoso, B; Guilhon, L; Kanashiro, M. \& Melgaço, L. (Orgs.). Tecnopolíticas da vigilância: perspectivas periféricas. São Paulo: Boitempo, 2018, p.69-90.

FIRMINO, R.; WOOD, D. M. Inclusão ou repressão? Questões de identificação e exclusão no Brasil. In: Bruno, Fernanda; Kanashiro, Marta e Firmino, Rodrigo. (Orgs.). Vigilância e visibilidade: espaço, tecnologia e identificação. Porto Alegre: Sulina, 2010, p. 248-271. 
FOLETTO, L. et al. Governo do Estado de São Paulo privatiza endereçamento ao Google. Uol Notícias, Blogosfera, Blog da Raquel Rolnik, A cidade é nossa, [São Paulo], 13 dez. 2019. Disponível em: <https://raquelrolnik.blogosfera.uol.com.br/2019/12/13/governo-do-estadode-sao-paulo-privatiza-enderecamento-ao-google/>. Acesso em: 22 jan. 2020.

FOLETTO, L.; ROLNIK, R. Câmeras de reconhecimento facial no espaço público usam dados sem nossa autorização. Labcidade, FAUUSP, [São Paulo] 22 jul. 2019. Disponível em: <http://www.labcidade.fau.usp.br/cameras-de-reconhecimento-facial-no-espaco-publicousam-dados-sem-nossa-autorizacao/>. Acesso em: 06 nov. 2019.

FOLHAPRESS. Aplicativos facilitam a busca de vagas para estacionar. Valor Econômico, São Paulo, 03 jan. 2014.2 Disponível em: <https://valor.globo.com/empresas/noticia/2014/02/03/aplicativos-facilitam-a-busca-devagas-para-estacionar.ghtml>. Acesso em 06 nov. 2019.

FORBES. 10 cidades mais inteligentes do mundo em 2018. Forbes, [S.I.]., 18 jul. 2018. Disponivel em: <https://forbes.com.br/listas/2018/07/10-cidades-mais-inteligentes-domundo-em-2018/>. Acesso em 10 fev. 2020.

FOUCAULT, M. Vigiar e Punir: nascimento da prisão. Petrópolis: Vozes, 1983.

FREEMAN, G.; NEMER, D. Empowering the Marginalized: Rethinking Selfies in the Slums of Brazil. International Journal of Communication (IJoC), USC, [S.I.], 2015, v. 9, p. 1832-1847. Disponível em: <https://ijoc.org/index.php/ijoc/article/view/3155/1403>. Acesso em: 17 jul. 2019.

G1. Museu high-tech: crianças falam com obras de arte na Pinacoteca de SP. G1, Fantástico [São Paulo], 02 abr. 2017.2 Disponível em: <http://g1.globo.com/fantastico/noticia/2017/04/museu-high-tech-criancas-falam-comobras-de-arte-na-pinacoteca-de-sp.html>. Acesso em: 06 nov. 2019.

Governo de SP revoga portaria que possibilitava empresas contratarem serviço com dados da população. G1, São Paulo, 14 jun. 2018a. em: <https://g1.globo.com/sp/sao-paulo/noticia/governo-de-sp-revoga-portaria-quepossibilitava-empresas-contratarem-servico-com-dados-da-populacao.ghtml>. Acesso em: 01 jan. 2020.

Após instalação de biometria facial, crianças portadoras de deficiência não conseguem andar de graça nos ônibus. G1, São Carlos e Araraquara, 26 jul. 2018b. Disponível em: <https://g1.globo.com/sp/sao-carlos-regiao/noticia/2018/07/26/apos-instalacao-debiometria-facial-criancas-portadoras-de-deficiencia-nao-conseguem-andar-de-graca-nosonibus.ghtml>. Acesso em: 22 ago. 2018.

Justiça de SP proíbe uso de câmeras de reconhecimento facial em painel do Metrô. G1 são Paulo, São Paulo, 14 set. 2018c. Disponível em: <https://g1.globo.com/sp/saopaulo/noticia/2018/09/14/justica-de-sp-proibe-uso-de-cameras-de-reconhecimento-facialem-painel-do-metro-de-sp.ghtml>. Acesso em: 13 dez. 2018. 
GAZZONI, M. Relógio de rua 'enviará' anúncios no celular. Estadão, [Rio de Janeiro], 11 jul. 2016. Disponível em: <https://economia.estadao.com.br/blogs/radar-dapropaganda/relogio-de-rua-enviara-anuncios-no-celular/>. Acesso em: 06 nov. 2019.

GIRARD, L. A programação total do ambiente: Infraestruturas planetárias da comunicação. 2017, 126 p. Dissertação de mestrado (Arquitetura e Urbanismo) - Faculdade de Arquitetura e Urbanismo, Universidade de São Paulo, São Paulo, 2017.

GRANVILLE, K. Como a Cambridge Analytica recolheu dados do Facebook. Folha de São Paulo, [S.I.]., 21 mar. 2018. Disponível em: <https://www1.folha.uol.com.br/mercado/2018/03/como-a-cambridge-analytica-recolheudados-do-facebook.shtml>. Acesso em: 01 fev. 2020.

GREENFIELD, A. Against the Smart City. New York: Do projects, 2017.

GOARD, A. San Francisco Parking App Makers Threatened With Fines, Lawsuit. NBC Bay Area [San Francisco, CA], 23 june 2014. Disponível em: $<$ https://www.nbcbayarea.com/news/local/san-francisco-parking-app-companies-orderedto-cease-and-desist-monkeyparking-sweetch-parkmodo/1988326/>. Acesso em: 06 nov. 2019.

GOVERNO DO ESTADO DE SÃO PAULO. Governo cria identificação biométrica e inicia emissão de CNH digital. Governo do Estado de São Paulo, São Paulo, 21 mar. 2018. Disponível em: <http://www.saopaulo.sp.gov.br/spnoticias/com-identificacao-biometrica-eletronicagoverno-inicia-emissao-da-cnh-digital/>. Acesso em: 24 ago. 2019.

Governo firma parceria inédita com Google para mapear propriedades e entradas rurais. Governo do Estado de São Paulo, São Paulo, 11 dez. 2019. Disponível em: <http://www.saopaulo.sp.gov.br/spnoticias/governo-de-sp-anuncia-parceria-inedita-paramapeamento-de-estradas-rurais/>. Acesso em: 22 jan. 2020.

HAN, B. No exame: perspectivas do digital. Petrópolis: Vozes, 2018.

HATUKA, T; TOCH, E. Being visible in public space: The normalization of asymmetrical visibility. [S.I.].: Urban Studies Journal Limited, 2017, v. 54, n. 4, p.984-998. Disponível em: <https://journals.sagepub.com/doi/10.1177/0042098015624384>. Acesso em: 24 abr. 2018.

IBGE online. Você foi procurado pelo IBGE? O IBGE protege meus dados? Disponível em: $<$ https://respondendo.ibge.gov.br/voce-foi-procurado-pelo-ibge/o-ibge-protege-meusdados.html>. Acesso em: 22 fev. 2019.

IMPRENSA OfICIAL DO ESTADO S/A IMESP. Aviso Público - Oferta de Novo serviço: Certificação Online de Identidade, por meio de dados biométricos e biográficos. Portal da Transparência, Controladoria-Geral da União, Documentos. [Brasília, DF]., 21 mar. 2018. Disponível em: <http://www.transparencia.sp.gov.br/conselho/documentos/68/Certifica\%C3\%A7\%C3\%A3o \%20online\%20de\%20identidade.pdf>. Acesso em 20 jan. 2020. 
JORNAL DA GLOBO. Tecnologia rastreia localização e impulsiona interesse do consumidor. Jornal da Globo, [S.I.]., 13 out. 2016. Disponível em: <https://globoplay.globo.com/v/5375779/>. Acesso em: 06 nov. 2019.

KANASHIRO, M. Sorria, você está sendo filmado: as câmeras de monitoramento para segurança em São Paulo. 2006. 123 p. Dissertação de mestrado (Sociologia) - Instituto de Filosofia e Ciências Humanas, Universidade Estadual de Campinas, Campinas, 2006.

KASPERKEVIC, J. Google says sorry for racist auto-tag in photo app. The Guardian, New York, 1 jul. 2015. Disponível em: <https://www.theguardian.com/technology/2015/jul/01/googlesorry-racist-auto-tag-photo-app>. Acesso em: 22 fev. 2019.

KAYYALI, D. As olimpíadas estão transformando o Rio em um Estado de vigilância e repressão. Motherboard Tech by Vice, [S.I.], 13 jun. 2016. Disponível em: $<$ https://www.vice.com/pt_br/article/ezbj9w/as-olimpiadas-estao-transformando-o-rio-emum-estado-de-vigilancia>. Acesso em: 06 nov. 2019

KNEBEL, P. CPqD e Taggen criam primeiro beacon nacional. Jornal do Comercio, [S.I.]., 30 maio $2016 . \quad$ Disponível em: <https://www.jornaldocomercio.com/_conteudo/2016/05/economia/500165-cpqd-etaggen-criam-primeiro-beacon-nacional.html>. Acesso em: 06 nov. 2019.

KEYES, O. The Misgendering Machines: Trans/HCl Implications of Automatic Gender Recognition. [S.I.]: Proc. ACM Hum.-Comput. Interact., 2018, v. 2, n. CSCW, article 88, 22 p. Disponível em: <https://doi.org/10.1145/3274357>. Acesso em: 06 nov. 2019.

KOSKELLA, H. Assista à fronteira 24/7 do seu sofá: o programa de observação virtual da fronteira do Texas e a política do informante. In: Bruno, F; Kanashiro, M; Firmino, R. (Orgs.). Vigilância e visibilidade: espaço, tecnologia e identificação. Porto Alegre: Sulina, 2010, p. 174187.

KUSTER, E; PECHMAN, R. O chamado da cidade. Belo Horizonte: UFMG, 2014.

LAVADO, T. Investigação hi-tech: como a polícia fuçou buscas e localização de celular para chegar aos suspeitos de matar Marielle. G1, [S.I.]., 12 mar. 2019.

Disponível

em:

<https://g1.globo.com/economia/tecnologia/noticia/2019/03/12/investigacao-hi-techcomo-a-policia-fucou-buscas-e-localizacao-de-celular-para-chegar-aos-suspeitos-de-matarmarielle.ghtml>. Acesso em 10 fev. 2020.

LEMOS, A. Mídias locativas e vigilância. Sujeito inseguro, bolhas digitais, paredes virtuais e territórios informacionais. In: Bruno, F; Kanashiro, M; Firmino, R. (Orgs.). Vigilância e visibilidade: espaço, tecnologia e identificação. Porto Alegre: Sulina, 2010, p. 61-93.

LIMA, J. D. O que está em jogo na expansão do wi-fi público em São Paulo. Nexo, [São Paulo], 19 jul. 2017. Disponível em: <https://www.nexojornal.com.br/expresso/2017/07/19/O-que- 
est\%C3\%A1-em-jogo-na-expans\%C3\%A3o-do-wi-fi-p\%C3\%BAblico-em-S\%C3\%A3o-Paulo>. Acesso em: 28 jan. 2020.

LYON, D. Cultura da vigilância: envolvimento, exposição e ética na modernidade digital. In: Bruno, F; Cardoso, B; Guilhon, L; Kanashiro, M. \& Melgaço, L. (Orgs.). Tecnopolíticas da vigilância: perspectivas periféricas. São Paulo: Boitempo, 2018, p.151-179.

MACHADO, J.; ORTELLADO, P.; RIBEIRO, M. (Orgs.). Privacidade e vigilância nos meios digitais. Rio de Janeiro: Liinc em Revista, nov. 2016, v.12, n.2. Disponível em: <http://revista.ibict.br/liinc/issue/view/203>. Acesso em: 28 fev. 2019.

MALUF, C. Espaço, tempo e lugar. Pós. Revista do Programa de Pós-Graduação em Arquitetura e Urbanismo da FAUUSP, São Paulo, n .23, p. 70-83, 1 jun. 2008

MARCHETTI, B. O metrô de São Paulo marcará sua cara para vender anúncios. Vice, Motherboard. [São Paulo], 19 abr. 2018. Disponível em: <https://www.vice.com/pt_br/article/j5a4vy/reconhecimento-facial-publicidade-metro>. Acesso em: 24 abr. 2018.

MELLO. P. C. Nordeste vira palco de guerra fria tecnológica entre EUA e China. Folha de São Paulo, [S.I.]., $30 \quad$ ago. 2019. Disponível em: <https://www1.folha.uol.com.br/mundo/2019/08/nordeste-vira-palco-de-guerra-friatecnologica-entre-eua-e-china.shtml>. Acesso em: 21 jan. 2020.

METAHEAVEN. Captives of the Cloud: Part I. E-flux Journal 37, [S.I.], sept. 2012, n.37, p. 1-14. Disponível em: <http://www.e-flux.com/journal/37/61232/captives-of-the-cloud-part-i/>. Acesso em: 06 nov. 2019.

METZ, R. Beyond San Francisco, more cities are saying no to facial recognition. CNN, [S.I.]., 17 jul. 2019. Disponível em: <https://edition.cnn.com/2019/07/17/tech/cities-ban-facialrecognition/index.html>. Acesso em: 06 nov. 2019.

MEYER, M. Entendendo o escândalo Facebook e Cambridge Analytica em 5 minutos. Oficina da Net, [S.I.]., 11 mar. 2018. Disponível em: <https://www.oficinadanet.com.br/facebook/22434-entendendo-o-escandalo-facebook-ecambridge-analytica-em-5-minutos>. Acesso em: 01 fev. 2020.

MINISTÉRIO DA CIÊNCIA, TECNOLOGIA, INOVAÇÕES E COMUNICAÇÕES. Secretaria de Política de Informática. Departamento de Políticas e Programas Setoriais em TICs. Estratégia Brasileira para a Transformação Digital (E-Digital) Brasília: Ministério da Ciência, Tecnologia, Inovações e Comunicações, 2018. Disponível em: <http://www.mctic.gov.br/mctic/export/sites/institucional/estrategiadigital.pdf>. Acesso em: 06 nov. 2019.

MINISTÉRIO DA SAÚDE. Secretaria de Vigilância em Saúde. Departamento de Vigilância Epidemiológica. Sistema de Informação de Agravos de Notificação - Sinan: normas e rotinas. Brasília, DF: Editora do Ministério da Saúde, 2007. Disponível em: 
<http://portalsinan.saude.gov.br/images/documentos/Aplicativos/sinan_net/Manual_Norm as_e_Rotinas_2_edicao.pdf >. Acesso em: $01 \mathrm{fev} .2020$.

MOLL, P; PARIZOT, C. The Vitual Watchers. Exposing the Invisible, 2016. Disponível em: $<$ https://exposingtheinvisible.org/resources/obtaining-evidence/the-virtual-watchers>.

Acesso em: 28 fev. 2019.

MORAES, B. Empresa Gaúcha de tecnologia fecha parceria com Botafogo-RJ. G1, [Porto Alegre, Rio de Janeiro], 06 nov. 2015. Disponível em: <http://g1.globo.com/rs/rio-grande-dosul/novos-futuros/noticia/2015/11/empresa-gaucha-de-tecnologia-fecha-parceria-com-obotafogo-rj.html>. Acesso em: 06 nov. 2019.

MOREIRA, M. A. Bilhete Único com foto não é mais produzido. Agora é Simples, OnBoard Mobility Brasil. 16 jun. 2019a. Disponível em: <https://www.agoraesimples.com.br/2019/06/16/bilhete-unico-com-foto-nao-e-maisproduzido/>. Acesso em 06 nov. 2019.

Reconhecimento facial e LGBT+, os desafios de uma tecnologia de massa. Agora é Simples, OnBoard Mobility. Brasil. 26 jun. 2019b. Disponível em: <https://www.agoraesimples.com.br/2019/06/26/reconhecimento-facial-lgbt-transportepublico/>. Acesso em 06 nov. 2019.

MOROZOV, E. Big tech - A ascensão dos dados e a morte da política. São Paulo: Ubu Editora, 2018.

MURAD, F. Clear Channel instala rede de beacons no Rio. Meio e Mensagem, [Rio de Janeiro], 10 jun. $2016 . \quad$ Disponível em: <https://www.meioemensagem.com.br/home/midia/2016/06/10/clear-channel-instalarede-de-beacons-no-rio.html>. Acesso em 06 nov. 2019.

NUNES, P. Novas ferramentas, velhas práticas: reconhecimento facial e policiamento no Brasil. In: Rede de observatórios da Segurança. Retratos da Violência Cinco meses de monitoramento, análise e descobertas Junho a outubro de 2019. [Rio de Janeiro]: Centro de Estudos de Segurança e Cidadania (CESeC) da Universidade Candido Mendes, 2019, p. 67-70. Disponível em: <http://observatorioseguranca.com.br/wpcontent/uploads/2019/11/1relatoriorede.pdf>. Acesso em: 06 nov. 2019.

O GLOBO. Cidade do Rio é eleita a mais inteligente e conectada do país. O globo, Rio de Janeiro, 03 ago. 2015. Disponível em: <https://oglobo.globo.com/rio/cidade-do-rio-eleitamais-inteligente-conectada-do-pais-17067390>. Acesso em 10 fev. 2020.

Tecnologia ajuda os motoristas dentro de túneis da cidade. O Globo, Rio de Janeiro, 13 dez. 2016. Disponível em: <https://oglobo.globo.com/rio/tecnologia-ajuda-osmotoristas-dentro-de-tuneis-da-cidade-20636700>. Acesso em: 06 nov. 2019.

ORLOV, R. Los Angeles moves to ban auction parking apps MonkeyParking, Haystack. Los Angeles Daily News, [Los Angeles], 12 nov. 2014. Disponível em: 
<https://www.dailynews.com/2014/11/12/los-angeles-moves-to-ban-auction-parking-appsmonkeyparking-haystack/>. Acesso em 06 nov. 2019.

PACIFIC. Direção: Marcelo Pedroso, Produção: Milena Times e Perola Braz. Brasil: Símio Filmes, Vitrine Filmes, 2009. DVD (72min), NTSC son., color.

PADRÃO, M. Caso Marielle: como celulares levaram a acusados e por que isso é um avanço. Uol, São Paulo, 13 mar. 2019. Disponível em: <https://www.uol.com.br/tilt/noticias/redacao/2019/03/13/como-os-celulares-ajudaram-aachar-o-assassino-de-marielle-franco.htm>. Acesso em 10 fev. 2020.

PAGNAM, R. Governo paulista vende serviço com dado sigiloso do RG de $\mathbf{3 0}$ milhões. Folha de São Paulo, São Paulo, 13 jun. 2018. Disponível em: <https://www1.folha.uol.com.br/cotidiano/2018/06/governo-paulista-vende-servico-comdado-sigiloso-do-rg-de-30-milhoes.shtml>. Acesso em: 01 jan. 2020.

PALMER, A. Waze launches Bluetooth 'Beacons' in New York City to prevent GPS blackspots and 'tunnel blindness' when drivers are underground. Dailymail, [S.I.]., 29 jan. 2019. Disponível em: <https://www.dailymail.co.uk/sciencetech/article-6644763/Waze-launchesBluetooth-Beacons-New-York-City-prevent-GPS-blackspots-tunnel-blindness.html>. Acesso em: 06 nov. 2019.

PELEGI, A. Liminar obriga Via Quatro a suspender coleta de emoções de usuários na Linha 4Amarela. Diário do Transporte, [São Paulo], 15 set. 2018. Disponível em: $<$ https://diariodotransporte.com.br/2018/09/15/liminar-obriga-via-quatro-a-suspendercoleta-de-emocoes-de-usuarios-na-linha-4-amarela/>. Acesso em: 13 dez. 2018.

PEQUENAS EMPRESAS \& GRANDES NEGÓCIOS. Startup lança aplicativo que busca vaga de estacionamentos para motoristas. G1, São Paulo, 04 ago. 2019. Disponível em: <https://g1.globo.com/economia/pme/pequenas-empresas-grandesnegocios/noticia/2019/08/04/start-up-lanca-aplicativo-que-busca-vaga-deestacionamentos-para-motoristas.ghtml>. Acesso em 06 nov. 2019.

PERIN, E. Beacon brasileiro chega ao mercado. RFID Journal Brasil, [S.I.]., 10 mar. 2017. Disponível em: <https://brasil.rfidjournal.com/noticias/vision?15808>. Acesso em: 06 nov. 2019.

PEZZOTTI, R. Ranking das cidades mais inteligentes do mundo tem representante do Brasil. Uol, São Paulo, 17 mar. 2019. Disponível em: <https://economia.uol.com.br/noticias/redacao/2019/03/17/rio-de-janeiro-ranking-cidadesinteligentes-smart-cities-sxsw.htm>. Acesso em 10 fev. 2020.

PORT AUTHORITY OF NEW YORK \& NEW JERSEY. Waze Beacons Rolls Out in New York City to Improve Tunnel Navigation. The Port Authoriy of New York \& New Jersey, [New York City], 29 jan. 2019. Disponível em: <https://old.panynj.gov/press-room/pressitem.cfm?headLine_id=3065>. Acesso em: 06 nov. 2019. 
PREFEITURA DE CAMBURIÚ. Camboriú instala aparelhos que se comunicam com turistas. Prefeitura de Camboriú, Camboriú, 08 mar. 2018. Disponível em: $<$ http://www.camboriu.sc.gov.br/noticias_mostra.php?idmateria=5746>. Acesso em $06 \mathrm{de}$ nov. 2019.

PREFEITURA DE SÃO PAULO. Idosos e portadores de deficiências terão acesso mais fácil nos ônibus e partir de domingo, dia 6. Prefeitura de São Paulo, Assessoria de Imprensa - SP Trans, São Paulo, $30 \quad$ nov. 2015.2 Disponível em: <https://www.prefeitura.sp.gov.br/cidade/secretarias/transportes/noticias/?p=207626>.

Acesso em 06 nov. 2019.

Prefeitura anuncia expansão do programa WiFi Livre SP. Prefeitura de São Paulo [São Paulo], 23 mar. 2019. Disponível em: <https://www.prefeitura.sp.gov.br/cidade/secretarias/inovacao/noticias/?p=267765>. Acesso em: 28 jan. 2020.

REIS, A. Doria "vender" dados de motoristas é invasão de privacidade, diz Proteste. UOL Carros, [São Pailo], 21 dez. 2017. Disponível em: <https://www.uol.com.br/carros/noticias/redacao/2017/12/21/doria-vender-dados-demotoristas-e-invasao-de-privacidade-diz-proteste.htm>. Acesso em: 28 jan. 2020.

RENNÓ, R. Smart cities e big data: o cidadão produtor de dados. Almería: URBS - Revista de Estudios Urbanos y Ciencias Sociales, 2016, v. 6, n.2, p.13-24. Disponível em: <http://www2.ual.es/urbs/index.php/urbs/article/view/renno>. Acesso em: 06 nov. 2019.

RICARDO, L. O documentário e o enigma da alteridade In: Predoso, Marcelo. (Coord.). Pacific: textos para debate. Recife: Edição André Antônio, 2011, p. 19-25.

RIO DE JANEIRO (Estado). Lei no 5628 de 29 de dezembro de 2009. Institui o bilhete único nos serviços de transporte coletivo intermunicipal de passageiros na região metropolitana do estado do Rio de Janeiro, e dá outras providências. Rio de Janeiro, RJ, 29 dez. 2009. Disponível em: <https://gov-rj.jusbrasil.com.br/legislacao/820940/lei-5628-09>. Acesso em 06 nov. 2019.

RODRIGUES, J. Nordeste esquece Bolsonaro e estreita relações com empresas chinesas. Metro1, São Paulo e Bahia, 30 ago. 2019. Disponível em: <https://www.metro1.com.br/noticias/brasil/79265, nordeste-esquece-bolsonaro-e-estreitarelacoes-com-empresas-chinesas>. Acesso em: 21 jan. 2020.

RODRIGUEZ, P. E. Espetáculo do dividual: tecnologias do eu e vigilância distribuída nas redes sociais. In: Bruno, F; Cardoso, B; Guilhon, L; Kanashiro, M. \& Melgaço, L. (Orgs.). Tecnopolíticas da vigilância: perspectivas periféricas. São Paulo: Boitempo, 2018, p.181-198.

ROTHMAN, P. O que torna o Rio uma das cidades mais inteligentes do mundo. Exame, [Rio de Janeiro], 24 set. 2014. Disponível em: <https://exame.abril.com.br/brasil/o-que-faz-do-riouma-das-cidades-mais-inteligentes-do-mundo/>. Acesso em 10 fev. 2020. 
ROZESTRATEN, A. S. Dúvidas, fantasias e delírio: smart cities, uma aproximação crítica. In: COLÓQUIO INTERNACIONAL IMAGINÁRIO, CONSTRUIR E HABITAR A TERRA, 1., 2016, São Paulo. Atas... São Paulo: FAUUSP, 2016. p. 17-32.

SALAS, J. Google conserta seu algoritmo "racista" apagando os gorilas. El País, [S.I.]., 16 jan. 2018. Disponível em: <https://brasil.elpais.com/brasil/2018/01/14/tecnologia/1515955554_803955.html>. Acesso em: 22 fev. 2019.

SANTOS, M. A natureza do espaço: técnica e tempo, razão e emoção. São Paulo: EDUSP, 2006.

SÃO PAULO (Estado). Decreto no 43680 de 09 de dezembro de 1998. Institui o sistema metropolitano de transportes públicos de passageiros da Região Metropolitana de São Paulo o Sistema METROPASS, processo de arrecadação de tarifas por meio de cartões inteligentes, e dá providências correlatas. Palácio dos Bandeirantes, São Paulo, SP, 09 dez. 1998. Disponível em: <https://governo-sp.jusbrasil.com.br/legislacao/168914/decreto-43680-98>. Acesso em 06 nov. 2019.

Decreto № 63.299, de 21 de março de 2018. Institui o Sistema Estadual de Coleta e Identificação Biométrica Eletrônica - Sistema Biométrico, e dá providências correlatas. Palácio dos Bandeirantes, São Paulo, SP, 21 mar. 2018a. Disponível em: <https://www.al.sp.gov.br/repositorio/legislacao/decreto/2018/decreto-63299-

21.03.2018.html>. Acesso em: 22 jan. 2019.

. Portaria Imesp - 3, de 21-3-2018. Diário Oficial do Estado de São Paulo, Caderno Executivo, p. 13. São Paulo, 22 mar 2018b. Disponível em: <https://www.imprensaoficial.com.br/DO/BuscaDO2001Documento_11_4.aspx?link=/2018/ executivo\%2520secao\%2520i/marco/22/pag_0013_5B3BP02A2C5EEe8PGBG52QSV9OM.pdf \&pagina $=13 \&$ data $=22 / 03 / 2018 \&$ caderno=Executivo\%20I\&paginaordenacao $=100013>$. Acesso em 20 jan. 2020.

Novo Sistema Biométrico facilita a identificação de cidadãos. Diário Oficial do Estado de São Paulo, Caderno Executivo, p. 1. São Paulo, 23 mar 2018c. Disponível em: <https://www.imprensaoficial.com.br/DO/BuscaDO2001Documento_11_4.aspx?link=/2018/ executivo\%2520secao\%2520i/marco/22/pag_0013_5B3BP02A2C5EEe8PGBG52QSV9OM.pdf \&pagina=13\&data $=22 / 03 / 2018 \&$ caderno=Executivo\%20I\&paginaordenacao $=100013>$. Acesso em 20 jan. 2020.

Aviso Público - Oferta de Novo serviço: Certificação Online de Identidade, por meio de dados biométricos e biográficos. Diário Oficial do Estado de São Paulo, Caderno Empresarial, p. 30. São Paulo, 16 maio 2018d. Disponível em: <https://www.imprensaoficial.com.br/DO/BuscaDO2001Documento_11_4.aspx?link=/2018/ empresarial/maio/16/pag_0030_46f157c418b2295cea1174f3fefaf1de.pdf\&pagina=30\&data =16/05/2018\&caderno=Empresarial\&paginaordenacao=100030>. Acesso em 20 jan. 2020.

SÃO PAULO SÃO. 'A voz da Arte': IBM Watson informa e responde perguntas sobre obras de arte da Pinacoteca de SP. São Paulo São, [São Paulo], 05 abr. 2017. Disponível em: 
<https://saopaulosao.com.br/negocios/2782-a-voz-da-arte-ibm-watson-informa-eresponde-perguntas-sobre-obras-de-arte-da-pinacoteca-de-sp.html\#>. Acesso em 06 nov. 2019.

SCHREDER, S. Does facial recognition software have a racial bias problem? Mozilla, Podcast: Face Value, [S.I.], 2018.2 Disponível em <https://blog.mozilla.org/internetcitizen/2018/02/05/irl-face-the-future/>. Acesso em: 22 fev. 2019.

SIBILIA, P. O show do eu. Rio de Janeiro: Contraponto, 2016.

SILVEIRA, S. A. Tudo sobre tod@s: Redes digitais, privacidade e venda de dados pessoais. São Paulo: Edições Sesc São Paulo, 2017.

SOPRANA, P. Dois milhões de moradores rurais de SP terão endereço fornecido pelo Google. Folha de São Paulo, São Paulo, 11 dez. 2019. Disponível em: <https://www1.folha.uol.com.br/tec/2019/12/dois-milhoes-de-moradores-rurais-de-spterao-endereco-fornecido-pelo-google.shtml>. Acesso em 22 jan. 2020.

TAGIAROLI, G. Como o Waze pretende acabar com o apagão de sinal em túneis. Gizmodo Brasil, Rio de Janeiro, 17 mar. 2019. Disponível em: <https://gizmodo.uol.com.br/wazeapagao-gps-tuneis-beacons/>. Acesso em: 06 nov. 2019.

TELE.SÍNTESE. SP terá serviço de consulta a impressões digitais dos cidadãos. Tele.Sìntese, [São Paulo], 22 mar. 2018. Disponível em: <http://www.telesintese.com.br/sp-tera-servicode-consulta-impressoes-digitais-dos-cidadaos/>. Acesso em: 01 jan. 2020.

TIINSIDE. Arteris anuncia adesão ao programa Connected Citizens do Waze. Tiinside, [S.I.]., 14 maio, 2018.2 Disponível em: <https://tiinside.com.br/tiinside/home/internet/14/05/2018/arteris-anuncia-adesao-aoprograma-connected-citizens-do-waze/>. Acesso em: 03 dez. 2019.

UNIVERSIDADE DE SÃO PAULO. Sistema Integrado de Bibliotecas da USP. Diretrizes para apresentação de dissertações e teses da USP: parte I (ABNT). 3a ed. rev. ampl. mod. São Paulo: SIBiUSP, 2016. 100 p.

UOL. Portas da linha 4 do metrô de SP vão reconhecer seu rosto e expressões. UOL, São Paulo, 13 abr. $2018 . \quad$ Disponível em: <https://tecnologia.uol.com.br/noticias/redacao/2018/04/13/com-cameras-emplataformas-linha-do-metro-de-sp-captara-reacoes-de-pessoas.htm>. Acesso em: 24 abr. 2018.

VALENTE, J. Tecnologias de reconhecimento facial são usadas em 37 cidades no país. Agência Brasil, São Paulo, 19 set. 2019. Disponível em: <http://agenciabrasil.ebc.com.br/geral/noticia/2019-09/tecnologias-de-reconhecimentofacial-sao-usadas-em-37-cidades-no-pais>. Acesso em: 21 jan. 2020. 
VENTURA, F. As menções ao Brasil nos e-mails vazados da Hacking Team. Gizmodo Brasil, [S.I.]., 10 jul. 2015. Disponível em: <https://gizmodo.uol.com.br/brasil-e-hacking-team/>. Acesso em 27 jan. 2020.

Ônibus adotam biometria facial em todo o Brasil para evitar fraudes. UOL, Gizmodo Brasil, [S.I.]., 18 dez. 2015. Disponível em: <https://gizmodo.uol.com.br/onibus-ebiometria-facial/>. Acesso em 06 nov. 2019.

MP investiga empresas que vendem reconhecimento facial no Brasil. Tecnoblog, [S.I.]., 17 ago. 2018. Disponível em: <https://tecnoblog.net/256136/mpdftempresas-reconhecimento-facial/>. Acesso em: 06 nov. 2019.

VIANA, N. Hackendo o Brasil. Pública, [S.I.]., 27 jul. 2015. Disponível em: <http://apublica.org/2015/07/hackeando-o-brasil/>. Acesso em 27 jan. 2020.

VIAQUATRO, Portas interativas digitais nas plataformas da Linha 4-Amarela. ViaQuatro, [São Paulo], 12 abr. 2018.2 Disponível em: <http://www.viaquatro.com.br/imprensa/noticias/Portas-interativas-digitais-nasplataformas-da-Linha-4-Amarela?releaseld=28601>. Acesso em 24 abr. 2018.

VIEIRA, T. Hipercidades. Folha de S. Paulo, [São Paulo], jan. 2019. Disponível em: <https://arte.folha.uol.com.br/mundo/2018/hipercidades/>. Acesso em 10 jan. 2019.

VIRILIO, P. The administration of fear. Los Angeles: Semiotext(e), 2012.

WERNECK, A. Reconhecimento facial falha em segundo dia, e mulher inocente é confundida com criminosa já presa. O GLOBO, [Rio de Janeiro], 11 jul. 2019. Disponível em: <https://oglobo.globo.com/rio/reconhecimento-facial-falha-em-segundo-dia-mulherinocente-confundida-com-criminosa-ja-presa-23798913>. Acesso em: 21 jan. 2020.

WISNIK, G. Dentro do nevoeiro: arquitetura, arte e tecnologia contemporâneas. São Paulo: Ubu Editora, 2018.

"Privacidade Hackeada" alerta para manipulação de dados obtidos no mundo virtual. Jornal da USP, [S.I.]., 10 out. 2019. Disponível em: $<$ https://jornal.usp.br/atualidades/privacidade-hackeada-alerta-para-manipulacao-dedados-obtidos-no-mundo-virtual/>. Acesso em: 01 fev. 2020.

WIKILEAKS. Hacking Team. WikiLeaks [S.I.]., 8 jul. 2015. Disponível em: <https://www.wikileaks.org/hackingteam/emails/emailid/446723>. Acesso em 27 jan. 2020.

ZAVRICK, L. Reconhecimento facial bloqueia 331 mil Bilhetes Únicos em SP. UOL, Folha de São Paulo, Agora São Paulo. São Paulo, 12 jun. 2019a. Disponível em: <https://agora.folha.uol.com.br/amp/sao-paulo/2019/06/reconhecimento-facial-bloqueia331-mil-bilhetes-unicos-em-sp.shtml>. Acesso em 06 nov. 2019.

. Quantidade de Bilhetes Únicos cancelados por fraude dispara em SP. UOL, Folha de São Paulo, Agora São Paulo, 02 jul. 2019b. Disponível em: 
<https://agora.folha.uol.com.br/sao-paulo/2019/07/quantidade-de-bilhetes-unicoscancelados-por-fraude-dispara-em-sp.shtml>. Acesso em 06 nov. $2019 \mathrm{~b}$.

ZHANG, M. Google Photos Tags Two African-Americans As Gorillas Through Facial Recognition Software. Forbes, [S.I.]., 1 jul. 2015. Disponível em: <https://www.forbes.com/sites/mzhang/2015/07/01/google-photos-tags-two-africanamericans-as-gorillas-through-facial-recognition-software/\#38d35cfc713d>. Acesso em: 22 fev. 2019.

ZUBOFF, S. Big Other: capitalismo de vigilância e perspectivas para uma civilização da informação. In: Bruno, F; Cardoso, B; Guilhon, L; Kanashiro, M. \& Melgaço, L. (Orgs.). Tecnopolíticas da vigilância: perspectivas periféricas. São Paulo: Boitempo, 2018, p.17-68. 